This document was prepared in conjunction with work accomplished under Contract No. DE-AC09-96SR18500 with the U. S. Department of Energy.

\title{
DISCLAIMER
}

This report was prepared as an account of work sponsored by an agency of the United States Government. Neither the United States Government nor any agency thereof, nor any of their employees, nor any of their contractors, subcontractors or their employees, makes any warranty, express or implied, or assumes any legal liability or responsibility for the accuracy, completeness, or any third party's use or the results of such use of any information, apparatus, product, or process disclosed, or represents that its use would not infringe privately owned rights. Reference herein to any specific commercial product, process, or service by trade name, trademark, manufacturer, or otherwise, does not necessarily constitute or imply its endorsement, recommendation, or favoring by the United States Government or any agency thereof or its contractors or subcontractors. The views and opinions of authors expressed herein do not necessarily state or reflect those of the United States Government or any agency thereof. 


\section{DEVELOPMENT OF AN ALTERNATIVE GLASS FORMULATION FOR VITRIFICATION OF EXCESS PLUTONIUM}

James C. Marra

David K. Peeler

Carol M. Jantzen

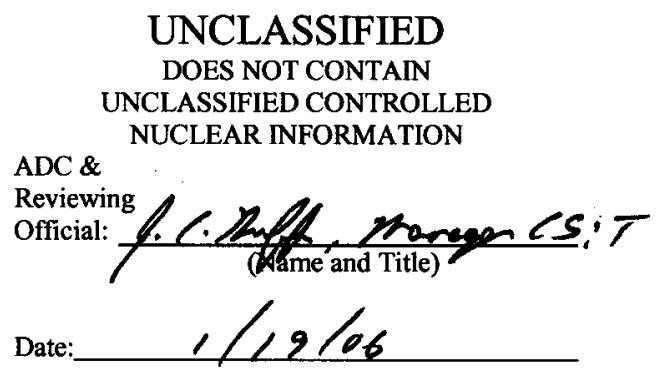

January 2006

Savannah River National Laboratory Aiken, SC 29808

Prepared for the U.S. Department of Energy Under Contract Numb DEAC09-96SR18500 


\section{DISCLAIMER}

This report was prepared by Washington Savannah River Company (WSRC) for the United States Department of Energy under Contract No. DE-AC09-96SR18500 and is an account of work performed under that contract. Neither the United States Department of Energy, nor WSRC, nor any of their employees makes any warranty, expressed or implied, or assumes any legal liability or responsibility for the accuracy, completeness, or usefulness, of any information, apparatus, or product or process disclosed herein or represents that its use will not infringe privately owned rights. Reference herein to any specific commercial product, process, or service by trademark, name, manufacturer or otherwise does not necessarily constitute or imply endorsement, recommendation, or favoring of same by WSRC or by the United States Government or any agency thereof. The views and opinions of the authors expressed herein do not necessarily state or reflect those of the United States Government or any agency thereof.

\section{Printed in the United States of America}

Prepared For U.S. Department of Energy 
Key Words:

Plutoniuim Disposition

Lanthanide Borosilicate (LaBS) Glass

Plutonium Glass

Retention: Permanent

\section{DEVELOPMENT OF ALTERNATIVE GLASS FORMULATIONS FOR VITRIFICATION OF EXCESS PLUTONIUM}

James C. Marra

David K. Peeler

Carol M. Jantzen

January 2006

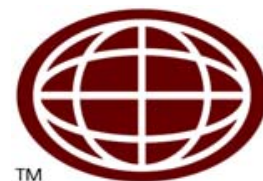


WSRC-TR-2006-00031

Revision 0

\section{REVIEWS AND APPROVALS}

\section{AUTHOR(S):}

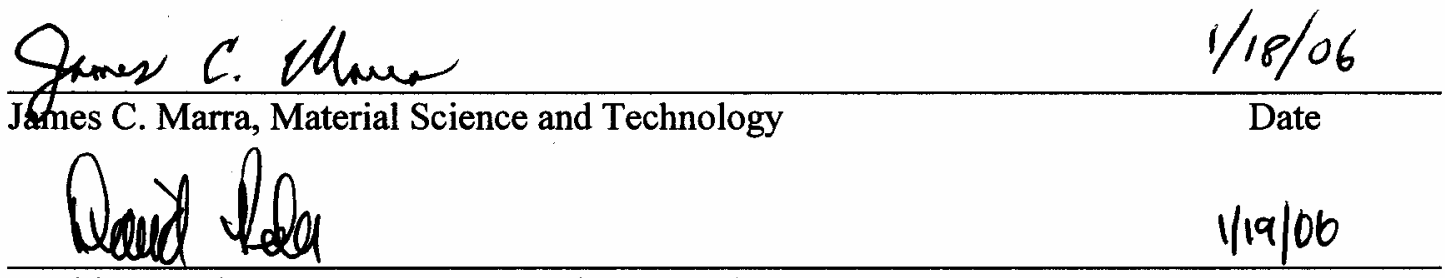

David K. Peeler, Process Science and Engineering

Date

$\begin{array}{cc}\text { Caual ne fantzen } & 1 / 19 / 06\end{array}$

\section{TECHNICAL REVIEWER:}

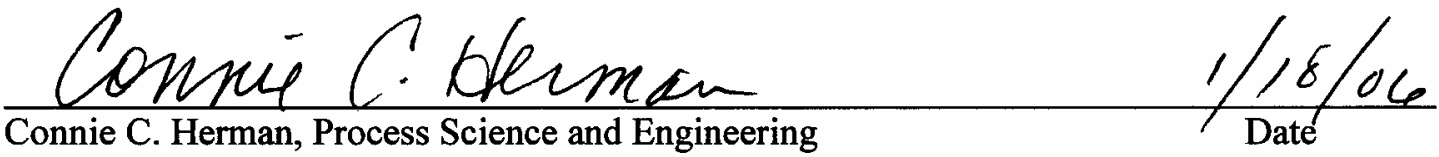

\section{APPROVERS}

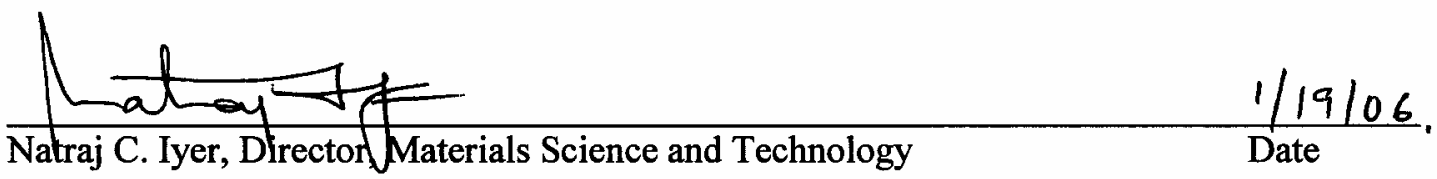

\begin{tabular}{lc} 
REEd $-d s$ & $1 / 19 / 06$ \\
\hline Richard E. Edwards, Manager, Process Science and Engineering & Date
\end{tabular}

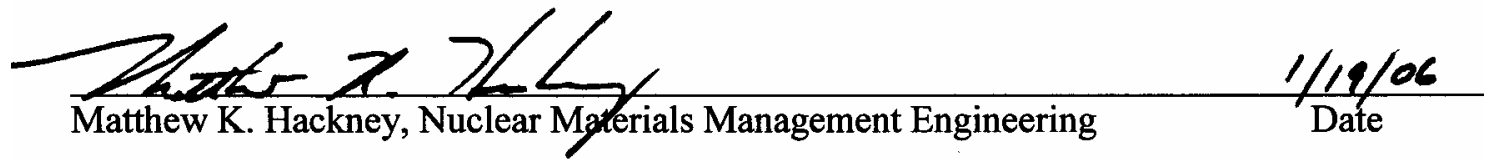




\section{EXECUTIVE SUMMARY}

The Department of Energy Office of Environmental Management (DOE/EM) plans to conduct the Plutonium Disposition Project at the Savannah River Site (SRS) to disposition excess weapons-usable plutonium. A plutonium glass waste form is a leading candidate for immobilization of the plutonium for subsequent disposition in a geologic repository. A reference glass composition (Lanthanide Borosilicate $\left(\underline{\mathrm{La}}_{2} \mathrm{O}_{3}-\underline{\mathrm{B}}_{2} \mathrm{O}_{3}-\underline{\mathrm{SiO}}_{2}(\mathrm{LaBS})\right)$ - Frit $\left.\mathrm{B}\right)$ was developed and testing with the LaBS Frit $\mathrm{B}$ composition is underway to provide data to support the Yucca Mountain License Application process. The objective of this task was to investigate alternative frit compositions and/or processing conditions that may improve the performance of the reference Frit B - LaBS glass in the repository. The current LaBS Frit B composition was used as the baseline for alternative glass formulation development efforts. A review of the literature and past high actinide concentration glass development efforts was conducted to formulate candidate compositions for testing. Glass science principles were also utilized to determine candidate frit components that may meet task objectives. Additionally, glass processing methods (e.g. slow cooling or induced heat treatment) were investigated as potential means to improve the glass durability and/or minimize fissile material and neutron absorber separation. Based on these analyses, a series of candidate surrogate glasses were fabricated and analyzed. One composition was then selected for fabrication with $\mathrm{PuO}_{2}$ and subsequently analyzed.

A phase equilibrium approach, developed from the assessment of previous high lanthanide glass formulations, was used to recommend modifications to the SRNL Frit B composition. A specific recommendation to increase $\mathrm{Ln}_{2} \mathrm{O}_{3}{ }^{a}$ content with concurrent reduction of $\mathrm{Al}_{2} \mathrm{O}_{3}$ and $\mathrm{SiO}_{2}$ content proved to be successful in improving the melting behavior and component solubility of the glass. This change moved the formulation from a compositional region of potential glass-in-glass phase separation toward a region near a low melting eutectic trough. The resulting LaBS Frit X composition was fabricated and tested.

The chemical durability of the LaBS Frit X glass was shown to be equivalent to the reference Frit $\mathrm{B}$ composition as measured by the Product Consistency Test (PCT). The Frit X composition demonstrated improved component solubility in surrogate and plutonium testing. This composition also exhibited improved devitrification behavior that could translate to lower glass processing temperatures and minimize any negative impacts on glass pouring.

Testing with the LaBS Frit $\mathrm{X}$ composition also indicated the potential to intentionally precipitate a $\mathrm{PuO}_{2}-\mathrm{HfO}_{2}$ solid solution phase. This could result in a means to dramatically improve the plutonium leach performance in the repository by the formation of a highly insoluble phase with an inherent neutron absorber. Preliminary testing indicated that glass heat treatment could be used to intentionally form this phase in the glass.

This study identified an alternative LaBS glass composition (Frit X) that should be tested further. Specifically, the suite of performance tests currently being conducted on the reference Frit B composition should be conducted on the Frit $\mathrm{X}$ composition to provide the necessary data for repository modeling. The potential to form a $\mathrm{PuO}_{2}-\mathrm{HfO}_{2}$ phase in the glass should also be further pursued as a potential means to improve waste form performance and criticality control.

Additionally, as the feed stream chemistry destined for disposition via vitrification is better defined, a thorough glass formulation variability study should be performed to demonstrate that feed variations can be accommodated in the glass. Finally, this composition should be utilized in melter testing to support project design initiatives.

${ }^{\mathrm{a}} \mathrm{Ln}_{2} \mathrm{O}_{3}$ refers to rare earth oxides such as $\mathrm{La}_{2} \mathrm{O}_{3}, \mathrm{Nd}_{2} \mathrm{O}_{3}, \mathrm{Gd}_{2} \mathrm{O}_{3}$, and $\mathrm{HfO}_{2}$. 


\section{TABLE OF CONTENTS}

EXECUTIVE SUMMARY ……………………………..................................................

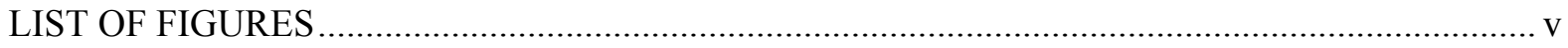

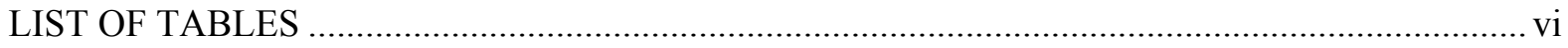

$1.0 \quad$ INTRODUCTION AND BACKGROUND ............................................................... 1

$1.1 \quad$ Previous Actinide Glass Formulation Development .................................................... 1

$2.0 \quad$ APPROACH

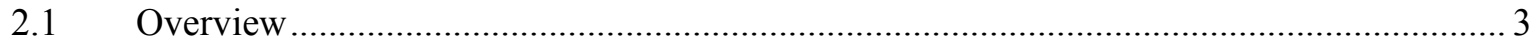

2.2 Rationale for Alternative Glass Compositions................................................................... 3

2.2.1 High Lanthanide Content Glass Compositions.............................................................. 3

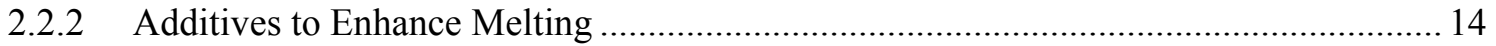

2.2.3 Increase in Neutron Absorber ............................................................................ 15

3.0 Experimental Procedures...................................................................................... 17

3.1.1 Simulant Glass Fabrication............................................................................... 17

3.1.2 Plutonium Glass Fabrication............................................................................. 19

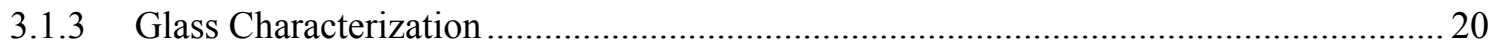

3.1.4 Product Consistency Testing ………………………………………………..... 20

3.1.5 Isothermal Heat Treatments............................................................................... 21

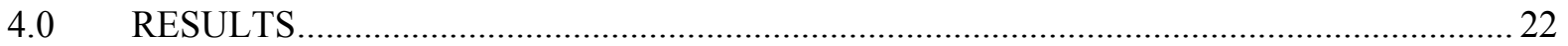

4.1 Simulant Glass Visual Observations........................................................................22

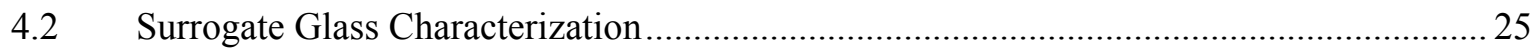

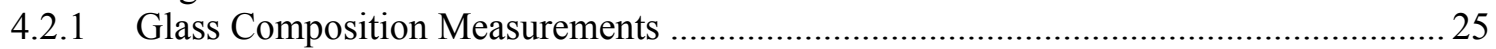

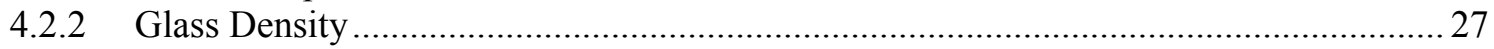

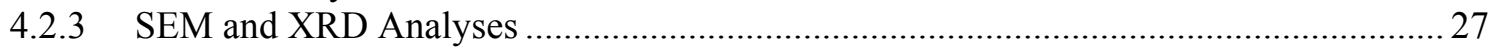

4.3 Surrogate Glass PCT Results .................................................................................. 30

4.4 Plutonium Glass Fabrication .................................................................................... 31

4.5 Plutonium Glass Characterization...................................................................................32

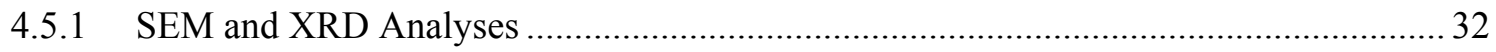

4.6 Glass Heat Treatment...………………………………………………………. 35

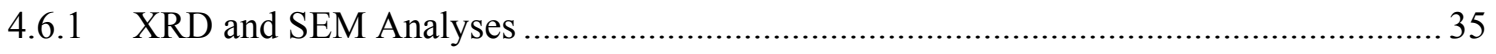

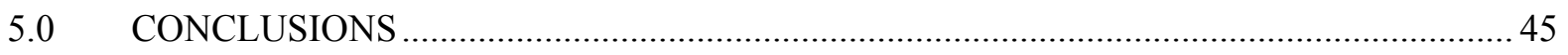

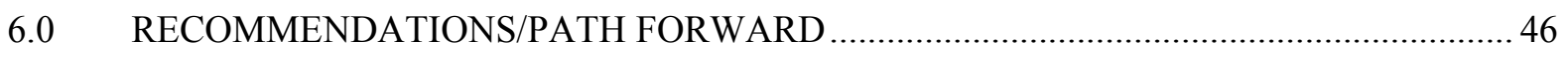

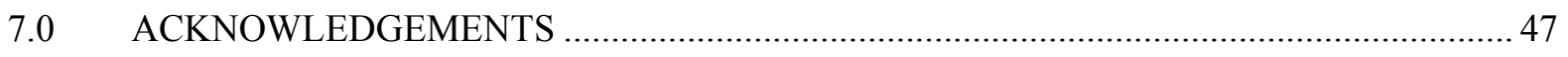

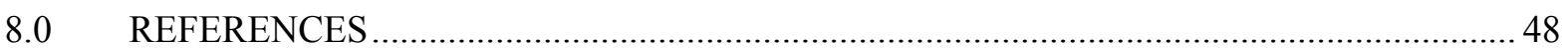




\section{LIST OF FIGURES}

Figure 1. Binary Oxide System $\mathrm{La}_{2} \mathrm{O}_{3}-\mathrm{SiO}_{2}$ (Figure 2372 from Phase Diagrams for Ceramists, Volume II, Amer. Ceramic Society, Westerville, Ohio, 1969).

Figure 2. Binary Oxide System $\mathrm{Sm}_{2} \mathrm{O}_{3}-\mathrm{SiO}_{2}$ (Figure 2386 from Phase Diagrams for Ceramists,

Volume II, Amer. Ceramic Society, Westerville, Ohio, 1969)................................................... 7

Figure 3. Binary Oxide System $\mathrm{La}_{2} \mathrm{O}_{3}-\mathrm{B}_{2} \mathrm{O}_{3}$ (Figure 321 from Phase Diagrams for Ceramists,

Volume I, Amer. Ceramic Society, Westerville, Ohio, 1964) ................................................ 8

Figure 4. Binary Oxide System $\mathrm{B}_{2} \mathrm{O}_{3}-\mathrm{SiO}_{2}$ (Figure 2353 from Phase Diagrams for Ceramists,

Volume II, Amer. Ceramic Society, Westerville, Ohio, 1969)................................................. 9

Figure 5. Ternary Oxide System $\mathrm{La}_{2} \mathrm{O}_{3}-\mathrm{B}_{2} \mathrm{O}_{3}-\mathrm{SiO}_{2}$ generated from the binary oxide systems shown in Figure 1 to Figure 4.

Figure 6. Molar ternary Oxide System $\mathrm{La}_{2} \mathrm{O}_{3}-\mathrm{B}_{2} \mathrm{O}_{3}-\left(\mathrm{SiO}_{2}+\mathrm{Al}_{2} \mathrm{O}_{3}\right)$ with compositions of SRNL

LaBS glass formulations tested to date.

Figure 7. Molar ternary Oxide System $\left(\mathrm{La}_{2} \mathrm{O}_{3}+\mathrm{XO}_{2}\right)-\mathrm{B}_{2} \mathrm{O}_{3}-\left(\mathrm{SiO}_{2}+\mathrm{Al}_{2} \mathrm{O}_{3}\right)$ with compositions of

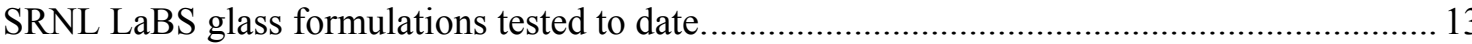

Figure 8. SEM micrograph and corresponding EDS spectrum for surrogate Frit B glass. ................ 28

Figure 9. SEM micrograph and corresponding EDS spectrum for surrogate High $\mathrm{Ln}_{2} \mathrm{O}_{3} \# 2 \mathrm{Mod}$

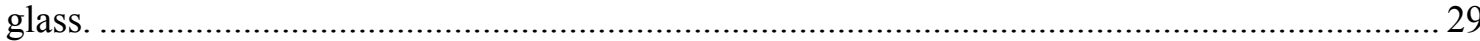

Figure 10. XRD scan for surrogate High $\mathrm{Ln}_{2} \mathrm{O}_{3} \# 2$ Mod glass. ................................................... 30

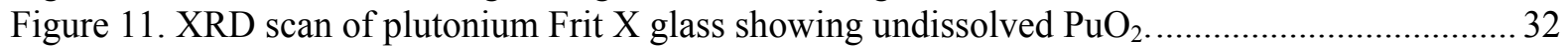

Figure 12. SEM micrograph and corresponding EDS spectra showing undissolved $\mathrm{PuO}_{2}$ in the

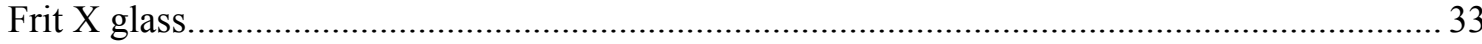

Figure 13. SEM micrograph and corresponding EDS spectra showing $\mathrm{PuO}_{2}-\mathrm{HfO}_{2}$ phase in the

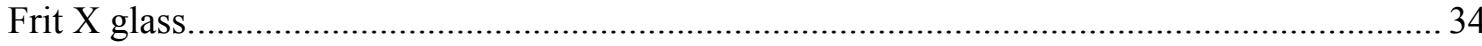

Figure 14. SEM micrograph and corresponding EDS spectra of surrogate Frit B glass from the $\mathrm{CIM}$ drain tube showing $\mathrm{HfO}_{2}-\mathrm{ZrO}_{2}$ phase glass precipitated in the glass............................... 36

Figure 15. SEM micrograph and corresponding EDS spectra of surrogate Frit B glass from CIM testing heat treated at $1400^{\circ} \mathrm{C}$.

Figure 16. XRD Scans for heat treated surrogate Frit X glass. ...................................................... 39

Figure 17. SEM micrograph and corresponding EDS spectra showing $\mathrm{HfO}_{2}$ phase precipitated in

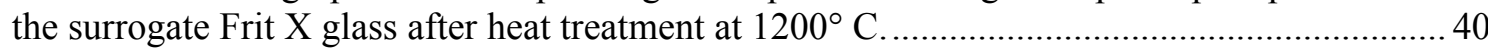

Figure 18. SEM micrograph and corresponding EDS spectra showing fine $\mathrm{HfO}_{2}$ phase precipitated in the surrogate Frit X glass after heat treatment at $1200^{\circ} \mathrm{C}$.

Figure 19. SEM micrograph and corresponding EDS spectra showing $\mathrm{HfO}_{2}$ phase precipitated in the plutonium-containing Frit X glass after heat treatment at $1200^{\circ} \mathrm{C}$

Figure 20. EDS spectra of spot 7 in Figure 4-11 with a beam current of $12 \mathrm{keV}$ 43

Figure 21. XRD Scan for plutonium-containing Frit X glass heat treated at $1200^{\circ} \mathrm{C}$. 44 


\section{LIST OF TABLES}

Table 1. Previously Developed Plutonium Frit Formulations (wt \%) ............................................... 2

Table 2. Comparative Oxide Compositions (Wt\%) of Lanthanide/Plutonium Borosilicate Glasses .... 5

Table 3. Target Composition of Baseline and Initial Alternative Frit Compositions (mass\%)......... 18

Table 4. Target Composition of Baseline and Initial Alternative Frit Compositions (mol \%)........... 18

Table 5. Mass of Glass Used to Support PCT Assessments of Surrogate Glasses..............................2 21

Table 6. Visual Observations of the "As Fabricated" Baseline and Alternative Pu-Glasses .............. 23

Table 7. Target Composition of Baseline and Initial Alternative Frit Compositions (mass\%).......... 24

Table 8. Visual Observations of High $\mathrm{Ln}_{2} \mathrm{O}_{3} \# 2$ Mod and High $\mathrm{Ln}_{2} \mathrm{O}_{3} \# 4$ Mod............................... 25

Table 9. Compositional Analysis of Select Alternative Surrogate Glasses (mass \%) ........................ 26

Table 10. Density Measurements for the Alternative Pu Glasses .................................................... 27

Table 11. Normalized Releases for Select Alternative Pu Glasses $(\mathrm{g} / \mathrm{L})$......................................... 30

Table 12. Measured vs. Targeted Composition for Frit X used in Pu Glass Fabrication .................... 31 


\subsection{INTRODUCTION AND BACKGROUND}

The Department of Energy Office of Environmental Management (DOE/EM) plans to conduct the Plutonium Disposition Project at the Savannah River Site (SRS) to disposition excess weapons-usable plutonium. Vitrification appears to be a viable option for the disposition of the plutonium. An important part of the vitrification approach is to reduce the attractiveness of the plutonium by fabricating a plutonium glass form and immobilizing the Pu form within the high level waste (HLW) glass prepared in the Defense Waste Processing Facility (DWPF). This requires the Pu Disposition Project schedule to be consistent with EM plans for immobilizing HLW in the DWPF. Therefore, several inputs are needed to provide confidence that the Pu Disposition Project will meet the project schedule. Key inputs are nearterm data that will increase confidence that a lanthanide borosilicate (LaBS) glass product is suitable for disposal in the Yucca Mountain Repository.

A workshop was held on April 28, 2005 at Bechtel SAIC Company (BSC) facility in Las Vegas, NV to define the near term data needs. Dissolution rate data and the fate of plutonium oxide and the neutron absorbers during the dissolution process were defined as key data needs. A suite of short-term tests were defined at the workshop to obtain the needed data. The objectives of these short-term tests are to obtain data that can be used to show that the dissolution rate of a LaBS glass is acceptable and to show that the extent of Pu separation from neutron absorbers, as the glass degrades and dissolves, is not likely to lead to criticality concerns. An additional data need was identified regarding the degree of macroscopic cracking that occurs during processing of the Pu glass waste form and subsequent pouring of HLW glass in the DWPF. A final need to evaluate new frit formulations that may increase the durability of the plutonium glass and/or decrease the degree to which neutron absorbers separate from the plutonium during dissolution was identified.

The potential for fissile material and neutron absorber separation is a criticality risk for the repository. The risk can be mitigated by either providing a glass that has a durability that is sufficiently high to preclude criticality even if separation of fissile material from the neutron absorbers occurs (i.e. Pu release rates so low to completely preclude criticality) or ensuring that sufficient neutron absorber is retained with the fissile material during dissolution. Bechtel SAIC Company is currently conducting analyses that will provide guidance concerning the maximum glass dissolution rate and maximum extent of $\mathrm{Pu} / \mathrm{neutron}$ absorber separation that are acceptable. Testing and analyses are underway with Frit B which may prove to meet repository requirements. However, it was deemed prudent to assess alternative compositions in parallel with these analyses. Past and future test results with the LaBS glass compositions will be evaluated against these requirements. This report summarizes the work completed to date to develop a new frit composition and/or processing strategy to improve the durability of the Pu glass and/or decrease the degree to which neutron absorbers separate from the plutonium during dissolution. Other data needs will be documented elsewhere.

\subsection{Previous Actinide Glass Formulation Development}

High lanthanide glass compositions were developed commercially in the 1930s for use in optical applications. ${ }^{1}$ This family of high lanthanide glasses has been used extensively in nuclear applications for protective purposes since many of the lanthanide elements have large thermal neutron cross-sections. ${ }^{2}$ The initial glass composition developed for the vitrification of plutonium was based on these high lanthanide content glasses with the expectation that the ability to accommodate high lanthanide content would translate to the accommodation of plutonium within the glass. ${ }^{3,4}$ The ability of high lanthanide content glasses to accommodate plutonium was demonstrated with this composition and the resulting 
glass was shown to exhibit excellent durability (as defined by the Product Consistency Test (PCT)). A drawback was identified with this composition, however, in that the formulation included listed Resource Conservation and Recovery Act (RCRA) metals namely lead and barium.

In support of the Plutonium Immobilization Program (PIP), plutonium glass formulation development continued with a concerted effort to remove the listed RCRA metals from the formulation yet still maintain high actinide solubility and excellent chemical durability. Efforts were successful in removing the RCRA metals and the initial composition Lanthanide Borosilicate (LaBS) composition was developed. ${ }^{5}$ This glass was later denoted as the LaBS Frit A composition. To prove the technical and economic feasibility of dispositioning excess weapons usable materials with the LaBS Frit A composition, it was necessary to demonstrate that $\mathrm{PuO}_{2}$ feedstock could be readily incorporated into glass in sufficient quantities. The results of these studies showed that $\mathrm{PuO}_{2}$ solubility could be as high as 13.4 wt \% (11.8 wt \% elemental $\mathrm{Pu})$ and that these quantities could be incorporated in the glass in less than 4 hours. ${ }^{6}$ Incorporation (complete dissolution) could be accomplished in as little as 1 hour with the assistance of agitation and/or using feed with fine particle sizes.

LaBS Frit A employed only gadolinium as a neutron absorber. When it was noted that incorporation of hafnium in the composition would benefit the criticality performance, hafnium replaced zirconium in the frit and the LaBS Frit B formulation was developed. ${ }^{7}$ Actinide solubility testing with the Frit B composition was primarily performed with combinations of plutonium and uranium to more accurately reflect the expected excess weapons useable plutonium feed streams. The solubility of combinations of plutonium and uranium was shown to be even higher than for $\mathrm{Pu}$ only. For example, a homogeneous glass containing $9 \mathrm{wt} \% \mathrm{PuO}_{2}$ and $6 \mathrm{wt} \% \mathrm{UO}_{3}$ was fabricated for a total actinide loading of $15 \mathrm{wt} \%{ }^{8}$ Previous PCT measurements on Frit A and Frit B based glasses have shown normalized boron releases on the order of approximately $0.02 \mathrm{~g} / \mathrm{L} .{ }^{9,10}$ It should be noted that these normalized release rates are better than two orders of magnitude lower as measured by the PCT than the Environmental Assessment (EA) glass that is currently used as the benchmark for disposition of HLW glasses in the repository. ${ }^{11}$

The primary frit compositions used to support previous assessments are shown in Table 1 (on a wt \% basis).

Table 1. Previously Developed Plutonium Frit Formulations (wt \%).

\begin{tabular}{|l|c|c|c|}
\hline Oxide & LOFFLER BASED & FRIT A & FRIT B \\
\hline $\mathrm{Al}_{2} \mathrm{O}_{3}$ & 9.0 & 21.5 & 21.3 \\
\hline $\mathrm{B}_{2} \mathrm{O}_{3}$ & 5.0 & 11.7 & 11.6 \\
\hline $\mathrm{BaO}$ & 2.0 & -- & -- \\
\hline $\mathrm{Gd}_{2} \mathrm{O}_{3}$ & -- & 8.6 & 12.8 \\
\hline $\mathrm{HfO}_{2}$ & -- & -- & 6.6 \\
\hline $\mathrm{La}_{2} \mathrm{O}_{3}$ & 18.3 & 12.4 & 8.1 \\
\hline $\mathrm{Nd}_{2} \mathrm{O}_{3}$ & 32.5 & 12.8 & 8.2 \\
\hline $\mathrm{PbO}$ & 7.9 & -- & -- \\
\hline $\mathrm{Pr}_{2} \mathrm{O}_{3}$ & 3.2 & & \\
\hline $\mathrm{SiO}_{2}$ & 21.5 & 29.2 & 28.9 \\
\hline $\mathrm{SrO}_{2}$ & -- & 2.5 & 2.5 \\
\hline $\mathrm{ZrO}_{2}$ & -- & 1.3 & -- \\
\hline
\end{tabular}




\subsection{APPROACH}

\subsection{Overview}

The objective of this task was to investigate alternative frit compositions and/or processing conditions that may improve the performance of the Pu glass in the repository. The current LaBS Frit B composition was used as the baseline for alternative glass formulation development efforts. A review of the literature and past high actinide concentration glass development efforts was conducted to formulate candidate compositions for testing. This included evaluation of previous testing with LaBS Frit A and Frit B compositions. Glass science structural principles were also utilized to determine candidate frit components. Additionally, glass processing methods (e.g. slow cooling or induced heat treatment) were investigated as potential means to improve the glass durability and/or minimize fissile material and neutron absorber separation. Surrogate testing (using $\mathrm{HfO}_{2}$ as a $\mathrm{PuO}_{2}$ surrogate) was conducted to evaluate the viability of candidate glass systems prior to radioactive testing. Physical and chemical property measurements were made on the surrogate glasses to assess their suitability. To assess the relative durability of these candidate glass compositions, the Product Consistency Test Method A (PCTA) was performed. ${ }^{12}$ The PCT results were compared with previous Pu LaBS glass PCT results to assess the viability of these alternative compositions. Based on the results of the surrogate testing, a candidate composition was selected for Pu glass fabrication and characterization.

\subsection{Rationale for Alternative Glass Compositions}

\subsubsection{High Lanthanide Content Glass Compositions}

The commercial lanthanide (rare earth) borosilicate glass upon which the $\mathrm{PuO}_{2}$ lanthanide glasses were based was first proposed by Loffler ${ }^{1,2}$ for use in technical applications where dichroic glasses were needed or for use as decorative highly colored glasses. ${ }^{1}$ The lanthanide glasses are known to accommodate Cs, Y, La-Hf (e.g. the lanthanide elements La, Ce, Pr, Nd, Pm, Sm, Eu, Gd, Tb, Dy, Ho, Er, Tm, Yb, and Lu) and the actinides in relatively high concentrations. ${ }^{2}$ Therefore, several LaBS glasses based on the Loffler formulation were investigated by SRNL for stabilization of excess weapons grade $\mathrm{PuO}_{2}$ as discussed in Section 1.1. The high lanthanide glasses were chosen for investigation rather than conventional borosilicate waste glasses that have inherently low solubilities for $\mathrm{PuO}_{2}$ because of the ability of the lanthanide glasses to solubilize actinides. Loffler's glass is unique in that it combines lanthanide oxides as fluxes in an aluminosilicate type glass in place of the usual alkali metal oxides. ${ }^{2}$ The glasses melt at conventional melting temperatures $\left(\geq 1350^{\circ} \mathrm{C}\right)$ but have an extraordinarily low viscosity. The Loffler glasses typically contain $10-70 \mathrm{wt} \%$ of some lanthanide oxides, 9-20 $\mathrm{wt} \% \mathrm{Al}_{2} \mathrm{O}_{3}$ and the remainder is $\mathrm{SiO}_{2}(21.5-46 \mathrm{wt} \%)$.

The first Loffler glass formulations for $\mathrm{PuO}_{2}$ stabilization were tested by Ramsey et. al. ${ }^{13}$ and were very similar to the Loffler composition given in Table 2. The Ramsey Loffler variants were able to stabilize anywhere from 1.85-17.62 wt $\% \mathrm{ThO}_{2}$ (a simulant for $\mathrm{PuO}_{2}$ ). $\mathrm{Ce}_{2} \mathrm{O}_{3}$ was used in place of the $\mathrm{La}_{2} \mathrm{O}_{3}$ and $\mathrm{Pr}_{2} \mathrm{O}_{3}$ in the Loffler formulation although a mixture of three lanthanide oxides was retained during all testing (Table 2). Additional testing substituted a variety of different rare earth elements (always a minimum of three) with little impact on the solubility of $\mathrm{ThO}_{2}$. This was consistent with the finding of the commercial glass industry that the substitution of various rare earths in the lanthanide borosilicate glasses had little effect on any measured physical properties. ${ }^{2}$ 
The Loffler and early Ramsey glasses contained hazardous Environmental Protection Agency (EPA) Resource and Recovery Act (RCRA) metal oxides such as $\mathrm{PbO}$ and $\mathrm{BaO}$ as discussed in Section 1.1. Subsequent formulations by Meaker ${ }^{5,14}$ substituted $\mathrm{Al}_{2} \mathrm{O}_{3}$ and $\mathrm{SrO}$ for the RCRA metal oxides $\mathrm{PbO}$ and $\mathrm{BaO}$ and began to examine what combinations of lanthanide oxides $\left(\mathrm{Gd}_{2} \mathrm{O}_{3}, \mathrm{La}_{2} \mathrm{O}_{3}\right.$, and $\left.\mathrm{Nd}_{2} \mathrm{O}_{3}\right)$ could be optimized with the actinides $\left(\mathrm{ThO}_{2}\right)$. The lanthanide $\mathrm{Gd}$ was chosen as a lanthanide that is also a neutron absorber needed to alleviate criticality concerns at high $\mathrm{PuO}_{2}$ concentrations in the glass. Samarium and europium oxides were also investigated. A maximum $\mathrm{ThO}_{2}$ loading of $25 \mathrm{wt} \%$ was achieved with one of the Meaker $\mathrm{Al}_{2} \mathrm{O}_{3} / \mathrm{SrO}$ formulations ${ }^{14}$ and this became the basis for the development of Frit A (Table 1). Further testing of Frit A glass at Pacific Northwest National Laboratory (PNNL) and Savannah River National Laboratory (SRNL) (Table 2) with $\mathrm{PuO}_{2}$ revealed that the maximum $\mathrm{PuO}_{2}$ concentration that could be accommodated in Frit A was $13.4 \mathrm{wt} \%$ and a concentration of $9.5 \mathrm{wt} \%$ was deemed acceptable for criticality concerns. Frit B partially substituted some $\mathrm{HfO}_{2}$ (an excellent neutron adsorber) for some $\mathrm{La}_{2} \mathrm{O}_{3}$ and $\mathrm{Nd}_{2} \mathrm{O}_{3}$ (Table 2).

The change from the $\mathrm{PbO} / \mathrm{BaO}$ bearing Loffler glasses to the $\mathrm{SrO} / \mathrm{Al}_{2} \mathrm{O}_{3}$ Frit A glasses caused the total $\mathrm{Ln}_{2} \mathrm{O}_{3}$ content of the glasses to decrease while the $\mathrm{Al}_{2} \mathrm{O}_{3}+\mathrm{SiO}_{2}$ content increased (Table 2). The additional modification to Frit $\mathrm{B}$ which added $\mathrm{HfO}_{2}$ in place of $\mathrm{Ln}_{2} \mathrm{O}_{3}$ caused a further decrease in the total $\mathrm{Ln}_{2} \mathrm{O}_{3}$ content (Table 2). At concentrations of lanthanide oxides, $\mathrm{Ln}_{2} \mathrm{O}_{3}$, in the range of $15 \mathrm{wt} \%$ the SRNL LaBS glass crystallized to lanthanum silicate phases and amorphous phase separation (APS) known as glass-in-glass phase separation was observed. ${ }^{14}$ In addition, the liquidus temperature of some of the LaBS formulations were shown to be too low, i.e.. the glass easily crystallized lanthanum silicates and oxides during pouring. ${ }^{15}$ Therefore, a glass formulation approach was needed that could be used to avoid regions of rare-earth silicate formation and regions of APS.

None of the ternary oxide phase relations are known in the $\mathrm{Ln}_{2} \mathrm{O}_{3}-\mathrm{B}_{2} \mathrm{O}_{3}-\mathrm{SiO}_{2}$ system. However, each of the binary oxide systems which comprise the binary sides of the ternary system are known, e.g. $\mathrm{Ln}_{2} \mathrm{O}_{3}$ $\mathrm{SiO}_{2}$ (Figure 1) and $\mathrm{Sm}_{2} \mathrm{O}_{3}-\mathrm{SiO}_{2}$ (Figure 2), $\mathrm{La}_{2} \mathrm{O}_{3}-\mathrm{B}_{2} \mathrm{O}_{3}$ (Figure 3), and $\mathrm{B}_{2} \mathrm{O}_{3}-\mathrm{SiO}_{2}$ (Figure 4). The phase diagrams for all the $\mathrm{Ln}_{2} \mathrm{O}_{3}-\mathrm{SiO}_{2}$ systems are similar (compare Figure 1 and Figure 2). $\mathrm{Ln}_{2} \mathrm{O}_{3}-\mathrm{SiO}_{2}$ system has three stoichiometric compounds, 1:1, 2:3 and 1:2 $\mathrm{Ln}_{2} \mathrm{O}_{3}$ : $\mathrm{SiO}_{2}$. Each $\mathrm{Ln}_{2} \mathrm{O}_{3}-\mathrm{SiO}_{2}$ system has a region of glass-in-glass phase separation at $>1: 2 \mathrm{Ln}_{2} \mathrm{O}_{3}: \mathrm{SiO}_{2}$ with lower stability temperatures of $\sim 1700^{\circ} \mathrm{C}$. Each $\mathrm{Ln}_{2} \mathrm{O}_{3}-\mathrm{SiO}_{2}$ system has one high temperature congruent melting lanthanide silicate compound at 1:1 $\mathrm{Ln}_{2} \mathrm{O}_{3}: \mathrm{SiO}_{2}$ and one incongruent melting lanthanide silicate compound at 1:2 $\mathrm{Ln}_{2} \mathrm{O}_{3}: \mathrm{SiO}_{2}$. Likewise, all the $\mathrm{Ln}_{2} \mathrm{O}_{3}-\mathrm{B}_{2} \mathrm{O}_{3}$ binary phase diagrams are similar.

In order to discuss the phase relations and regions of low melting eutectics in the $\mathrm{Ln}_{2} \mathrm{O}_{3}-\mathrm{B}_{2} \mathrm{O}_{3}-\mathrm{SiO}_{2}$ system, the $\mathrm{Ln}_{2} \mathrm{O}_{3}-\mathrm{B}_{2} \mathrm{O}_{3}-\mathrm{SiO}_{2}$ system will be inferred from the projections of the pertinent binary oxide systems (using $\mathrm{La}_{2} \mathrm{O}_{3}-\mathrm{SiO}_{2}$ and the $\mathrm{B}_{2} \mathrm{O}_{3}-\mathrm{SiO}_{2}$ systems as the prime example). In this manner the ternary phase relations regarding crystallization and phase separation can be related to the composition of the fluid melts observed by Loffler and the SRNL LaBS glass research to date.

Since the binary oxide systems given in Figure 1 to Figure 4 are in mole \% oxide, the compositions from Table 2 have been converted from oxide wt $\%$ to oxide mole \%. All of the $\mathrm{Ln}_{2} \mathrm{O}_{3}$ have been grouped together and the phase equilibria analyzed with $\mathrm{SiO}_{2}$ as the only glass former and with $\left(\mathrm{SiO}_{2}+\mathrm{Al}_{2} \mathrm{O}_{3}\right)$ grouped with $\mathrm{SiO}_{2}$ due to their similar structural role as glass formers. For the Loffler glass, this simplification of the glass chemistry (including the contribution of the $\mathrm{Al}_{2} \mathrm{O}_{3}$ ) accounts for $89.5 \mathrm{wt} \%$ of the glass components. For the SRNL LaBS Pu glass, this simplification (including the contribution of the $\mathrm{Al}_{2} \mathrm{O}_{3}$ ) accounts for $\sim 88 \mathrm{wt} \%$ of the glass chemistry variation. 
Table 2. Comparative Oxide Compositions (Wt\%) of Lanthanide/Plutonium Borosilicate Glasses

\begin{tabular}{|c|c|c|c|c|c|c|c|c|c|c|c|}
\hline Oxide & $\begin{array}{l}\text { Loffler } \\
\text { Glass }^{\text {b }}\end{array}$ & $\begin{array}{c}\text { Ramsey } \\
\text { Loffler } \\
\mathrm{ThO}_{2-1}\end{array}$ & $\begin{array}{c}\text { Ramsey } \\
\text { Loffler } \\
\mathrm{ThO}_{2}-2\end{array}$ & $\begin{array}{c}\text { Meaker } \\
\text { Loffler } \\
\mathrm{ThO}_{2}\end{array}$ & $\begin{array}{c}\mathrm{LaBS} \\
\text { PNNL } \\
\mathrm{PuO}_{2}\end{array}$ & $\begin{array}{l}\mathrm{LaBS} \\
\text { Frit A } \\
\mathrm{PuO}_{2}\end{array}$ & $\begin{array}{l}\text { LaBS } \\
\text { Frit B } \\
\mathrm{PuO}_{2}\end{array}$ & $\begin{array}{l}\text { LaBS } \\
\text { Frit X } \\
\mathrm{PuO}_{2}\end{array}$ & $\begin{array}{c}\mathrm{LaBS} \\
\text { Frit B } \\
\mathrm{ZrO}_{2}\end{array}$ & $\begin{array}{l}\text { LaBS } \\
\text { Frit B } \\
\mathrm{HfO}_{2}\end{array}$ & $\begin{array}{l}\text { LaBS } \\
\text { Frit X } \\
\mathrm{HfO}_{2}\end{array}$ \\
\hline $\mathrm{Al}_{2} \mathrm{O}_{3}$ & 9.0 & 9.08 & 3.58 & 16.25 & 19.04 & 19.46 & 19.27 & 9.05 & 20.35 & 19.17 & 9.00 \\
\hline $\mathrm{BaO}$ & 2.0 & 2.02 & 2.14 & - & - & - & - & - & - & - & - \\
\hline $\mathrm{B}_{2} \mathrm{O}_{3}$ & 5.0 & 5.05 & 7.88 & 8.85 & 10.4 & 10.59 & 10.50 & 11.77 & 11.07 & 10.44 & 11.70 \\
\hline $\mathrm{Ce}_{2} \mathrm{O}_{3}\left(\mathrm{Pr}_{2} \mathrm{O}_{3}\right)$ & $(3.2)$ & 18.61 & - & - & - & - & - & - & - & - & - \\
\hline $\mathrm{Gd}_{2} \mathrm{O}_{3}$ & - & - & - & 17.16 & 7.61 & 7.78 & 11.58 & 12.22 & 12.23 & 11.52 & 12.15 \\
\hline $\mathrm{HfO}_{2}$ (frit component) & - & - & - & - & - & - & 5.97 & 6.34 & 6.23 & 5.94 & 6.30 \\
\hline $\mathrm{HfO}_{2}\left(\mathrm{PuO}_{2}\right.$ surrogate $)$ & - & - & - & - & - & - & - & - & - & 10.00 & 10.00 \\
\hline $\mathrm{La}_{2} \mathrm{O}_{3}$ & 18.3 & 0.91 & 1.21 & 3.80 & 11.01 & 11.22 & 7.33 & 17.20 & 7.70 & 7.29 & 17.10 \\
\hline $\mathrm{Nd}_{2} \mathrm{O}_{3}$ & 32.5 & 32.81 & 34.76 & 4.05 & 11.37 & 11.58 & 7.42 & 13.58 & 7.80 & 7.38 & 13.50 \\
\hline $\mathrm{PbO}$ & 7.9 & 7.97 & 8.44 & - & - & - & - & - & - & - & - \\
\hline $\mathrm{PuO}_{2}\left(\mathrm{Pu}_{2} \mathrm{O}_{3}\right)$ & - & - & - & - & 11.39 & $9.50 \dagger$ & 9.50 & 9.50 & - & - & - \\
\hline $\mathrm{SiO}_{2}$ & 21.5 & 21.7 & 24.36 & 22.0 & 25.80 & 26.43 & 26.15 & 18.10 & 27.52 & 26.01 & 18.00 \\
\hline $\mathrm{SrO}(\mathrm{CaO}+\mathrm{ZnO})$ & - & - & - & 1.9 & 2.22 & 2.26 & 2.26 & 2.26 & 2.42 & 2.25 & 2.25 \\
\hline $\mathrm{ThO}_{2}\left(\mathrm{PuO}_{2}\right.$ surrogate $)$ & - & 1.85 & 17.62 & 25 & 11.39 & - & - & - & - & - & - \\
\hline $\mathrm{ZrO}_{2}$ (frit component) & - & - & - & 1 & 1.15 & 1.18 & - & - & - & - & - \\
\hline $\mathrm{ZrO}_{2}\left(\mathrm{PuO}_{2}\right.$ surrogate $)$ & - & - & - & - & - & - & - & - & 4.56 & - & - \\
\hline $\mathrm{Na}_{2} \mathrm{O}$ and $\mathrm{Li}_{2} \mathrm{O}$ & - & - & - & - & - & - & - & - & - & - & - \\
\hline Melt Temp $\left({ }^{\circ} \mathrm{C}\right)$ & 1350 & 1400 & 1425 & 1475 & $\begin{array}{c}1450- \\
1500\end{array}$ & 1500 & 1500 & 1500 & 1500 & 1500 & 1500 \\
\hline Total $\mathrm{Ln}_{2} \mathrm{O}_{3}$ & 54.0 & 52.33 & 35.97 & 25.0 & 29.99 & 30.58 & 26.33 & 43.00 & 27.73 & 26.19 & 42.75 \\
\hline $\mathrm{Ln}_{2} \mathrm{O}_{3}+(\mathrm{Th}, \mathrm{Zr}, \mathrm{Hf}) \mathrm{O}_{2}$ & 54.0 & 54.18 & 53.59 & 51.0 & 45.16 & 40.08 & 41.80 & 58.84 & 38.52 & 42.13 & 59.05 \\
\hline $\mathrm{SiO}_{2}+\mathrm{Al}_{2} \mathrm{O}_{3}$ & 30.5 & 30.78 & 27.94 & 38.25 & 44.84 & 45.89 & 45.42 & 27.15 & 47.87 & 45.18 & 27.00 \\
\hline Reference & {$[2]$} & $\begin{array}{c}\text { WSRC- } \\
\text { NB-93-77, } \\
\text { p.9 }\end{array}$ & $\begin{array}{c}\text { WSRC- } \\
\text { NB-93-77, } \\
\text { p. } 23\end{array}$ & $\begin{array}{l}\text { WSRC- } \\
\text { TR-96- } \\
0323\end{array}$ & $\begin{array}{c}\text { PNNL- } \\
11346\end{array}$ & $\begin{array}{c}\text { WSRC- } \\
\text { TR-96- } \\
0322\end{array}$ & $\begin{array}{l}\text { WSRC- } \\
\text { RP-97- } \\
00902\end{array}$ & This report & {$[15]$} & This report & This report \\
\hline SUM & 99.4 & 100 & 99.99 & 100.01 & 99.99 & 100 & 99.98 & 100.02 & 99.88 & 100.00 & 100.00 \\
\hline
\end{tabular}

\footnotetext{
${ }^{\mathrm{b}}$ This glass also has $0.1 \mathrm{wt} \% \mathrm{As}_{2} \mathrm{O}_{5}$ as a fining agent

$\dagger$ maximum waste loading determined to be $13.4 \mathrm{wt} \% \mathrm{PuO}_{2}$
} 


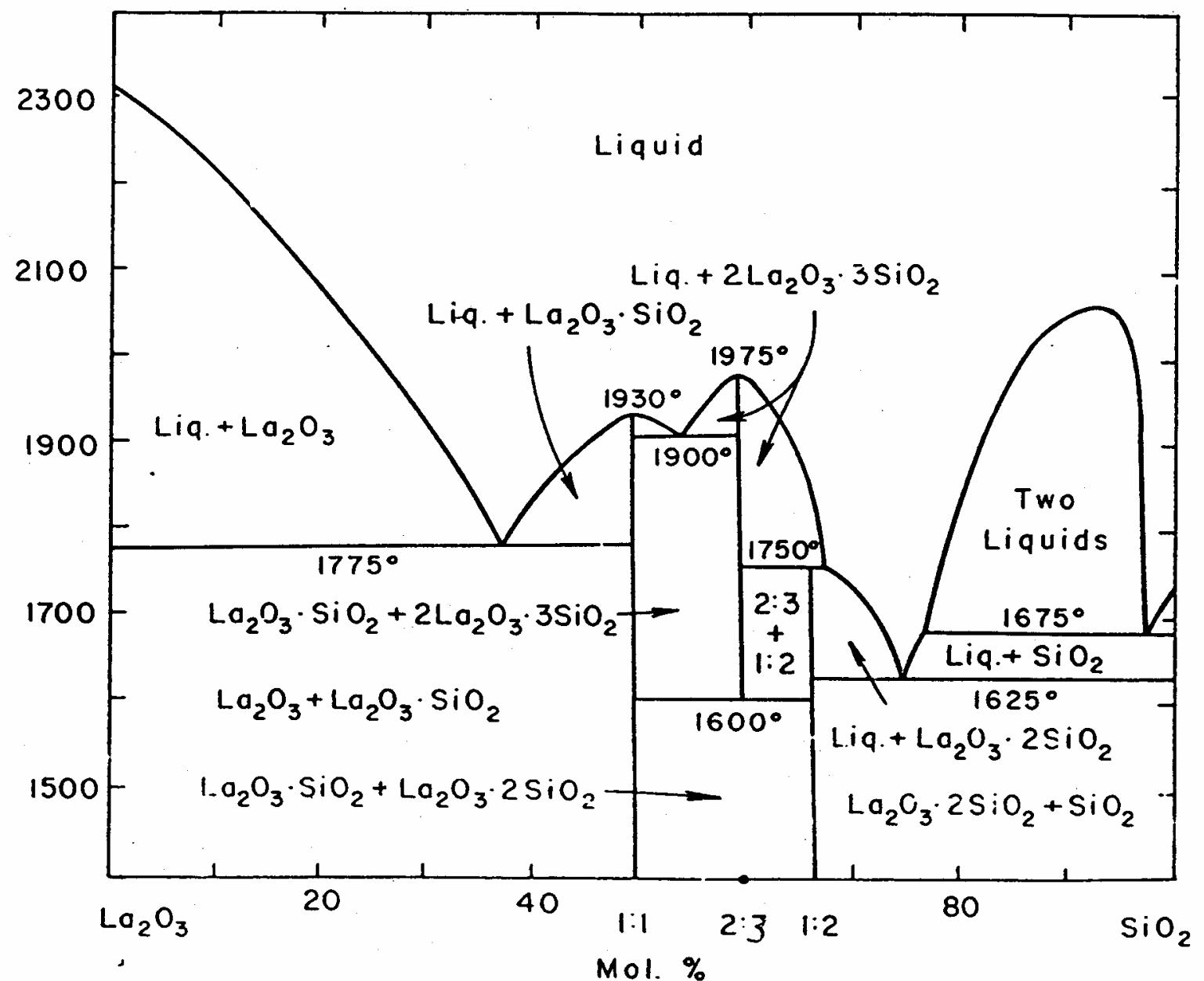

Figure 1. Binary Oxide System $\mathrm{La}_{2} \mathrm{O}_{3}-\mathrm{SiO}_{2}$ (Figure 2372 from Phase Diagrams for Ceramists, Volume II, Amer. Ceramic Society, Westerville, Ohio, 1969) 


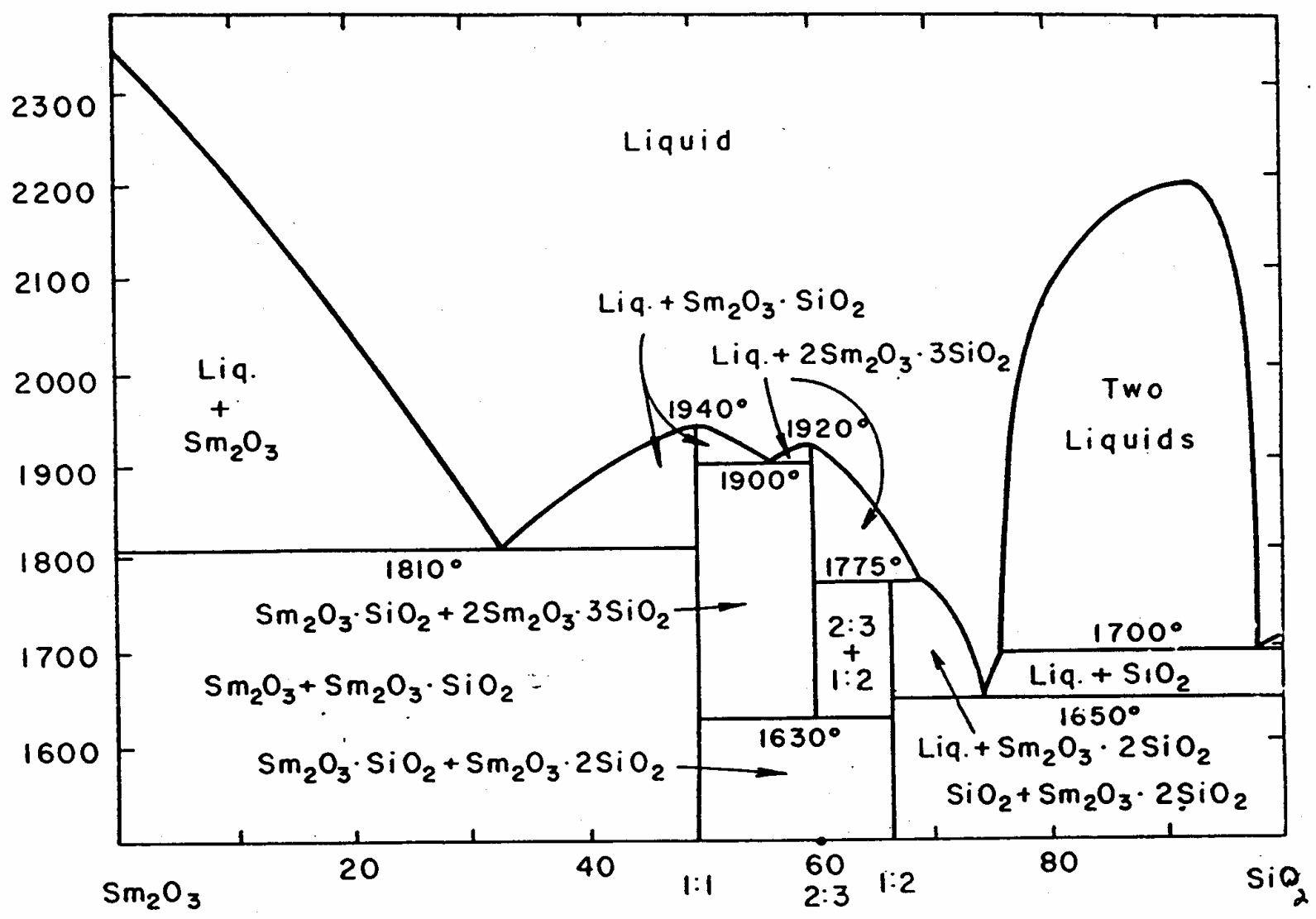

Mol. \%

Figure 2. Binary Oxide System $\mathrm{Sm}_{2} \mathrm{O}_{3}-\mathrm{SiO}_{2}$ (Figure 2386 from Phase Diagrams for Ceramists, Volume II, Amer. Ceramic Society, Westerville, Ohio, 1969) 


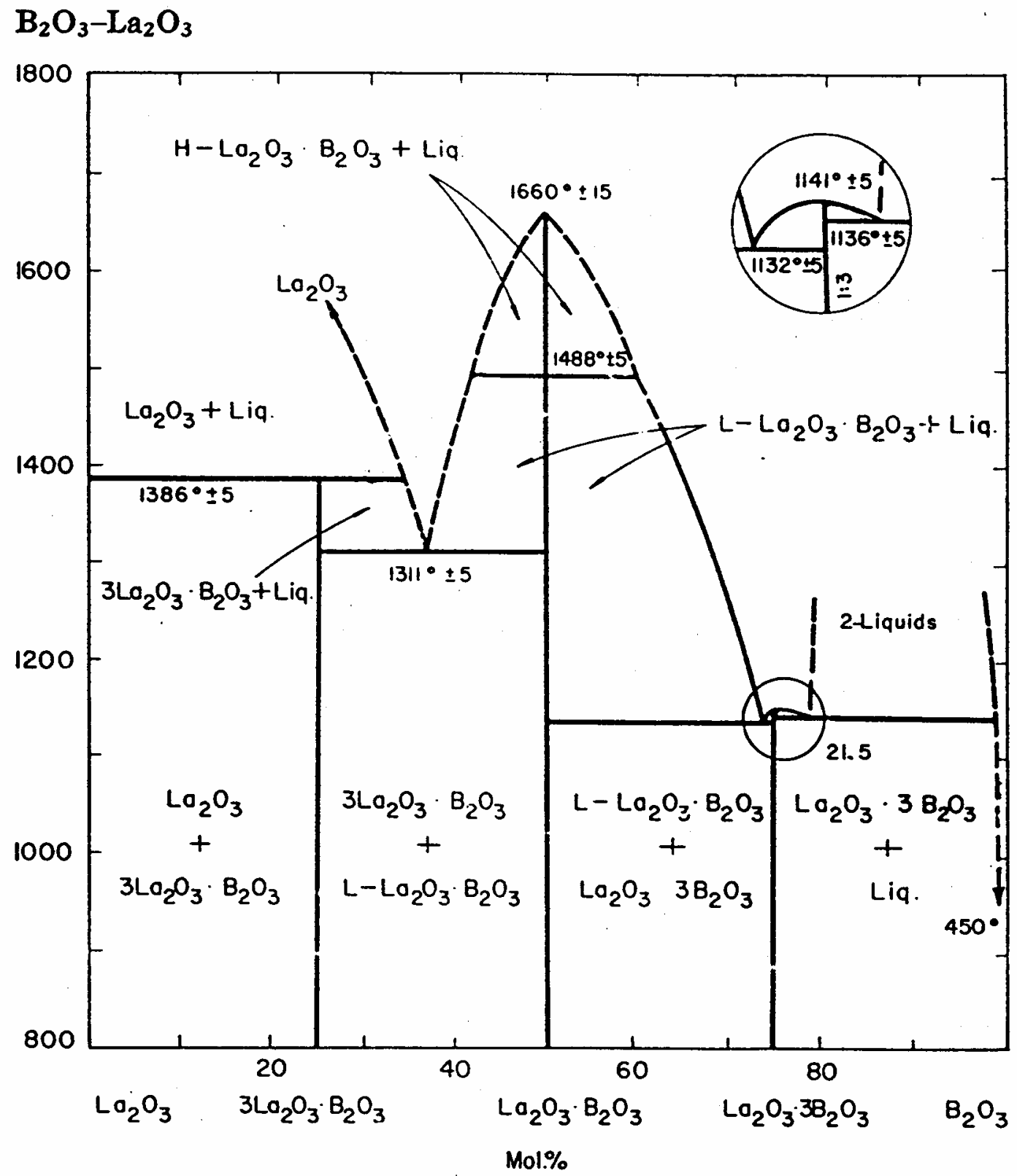

Figure 3. Binary Oxide System $\mathrm{La}_{2} \mathrm{O}_{3}-\mathrm{B}_{2} \mathrm{O}_{3}$ (Figure 321 from Phase Diagrams for Ceramists, Volume I, Amer. Ceramic Society, Westerville, Ohio, 1964) 
Revision 0

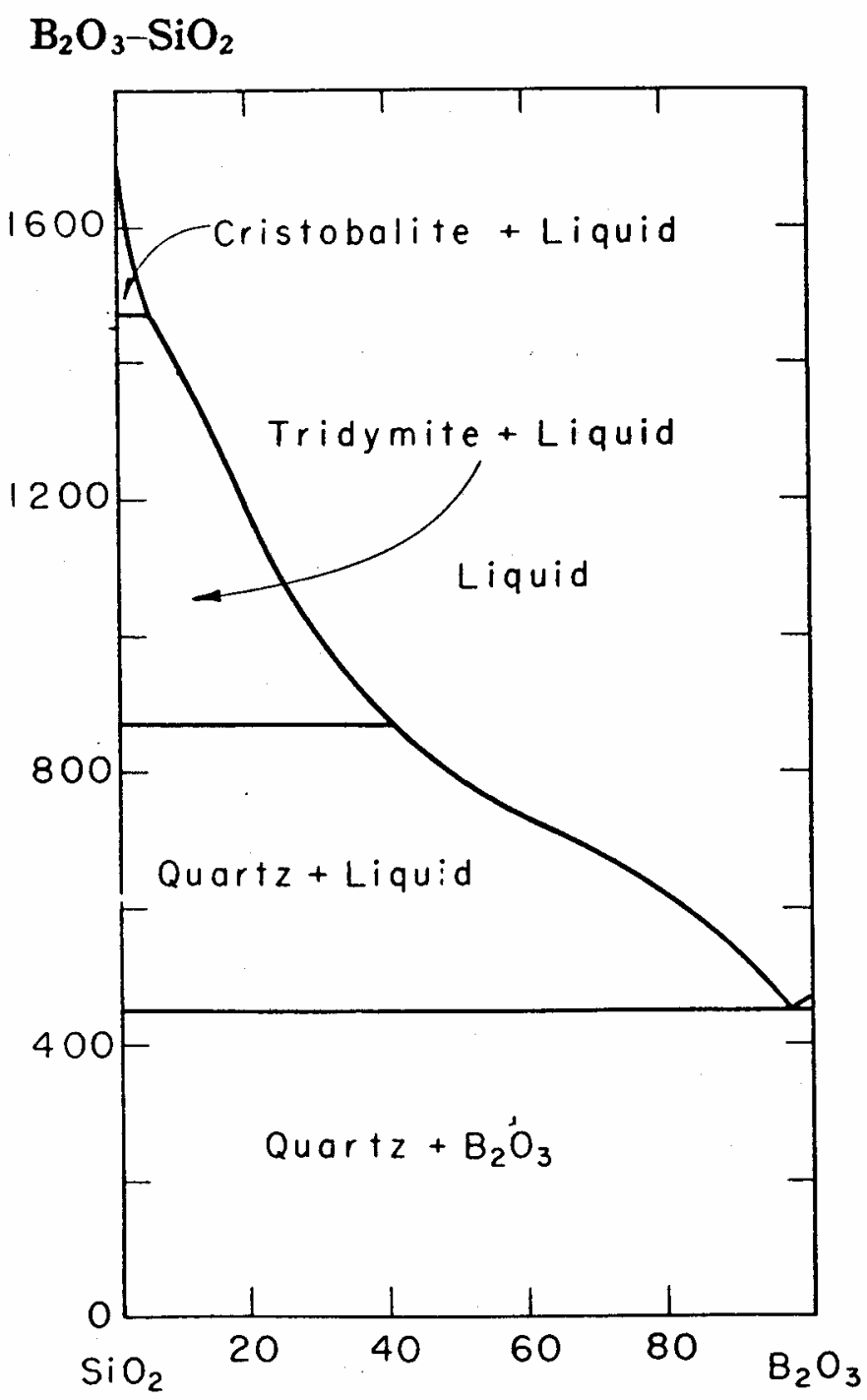

Figure 4. Binary Oxide System $\mathrm{B}_{2} \mathrm{O}_{3}-\mathrm{SiO}_{2}$ (Figure 2353 from Phase Diagrams for Ceramists, Volume II, Amer. Ceramic Society, Westerville, Ohio, 1969) 
WSRC-TR-2006-00031

Revision 0

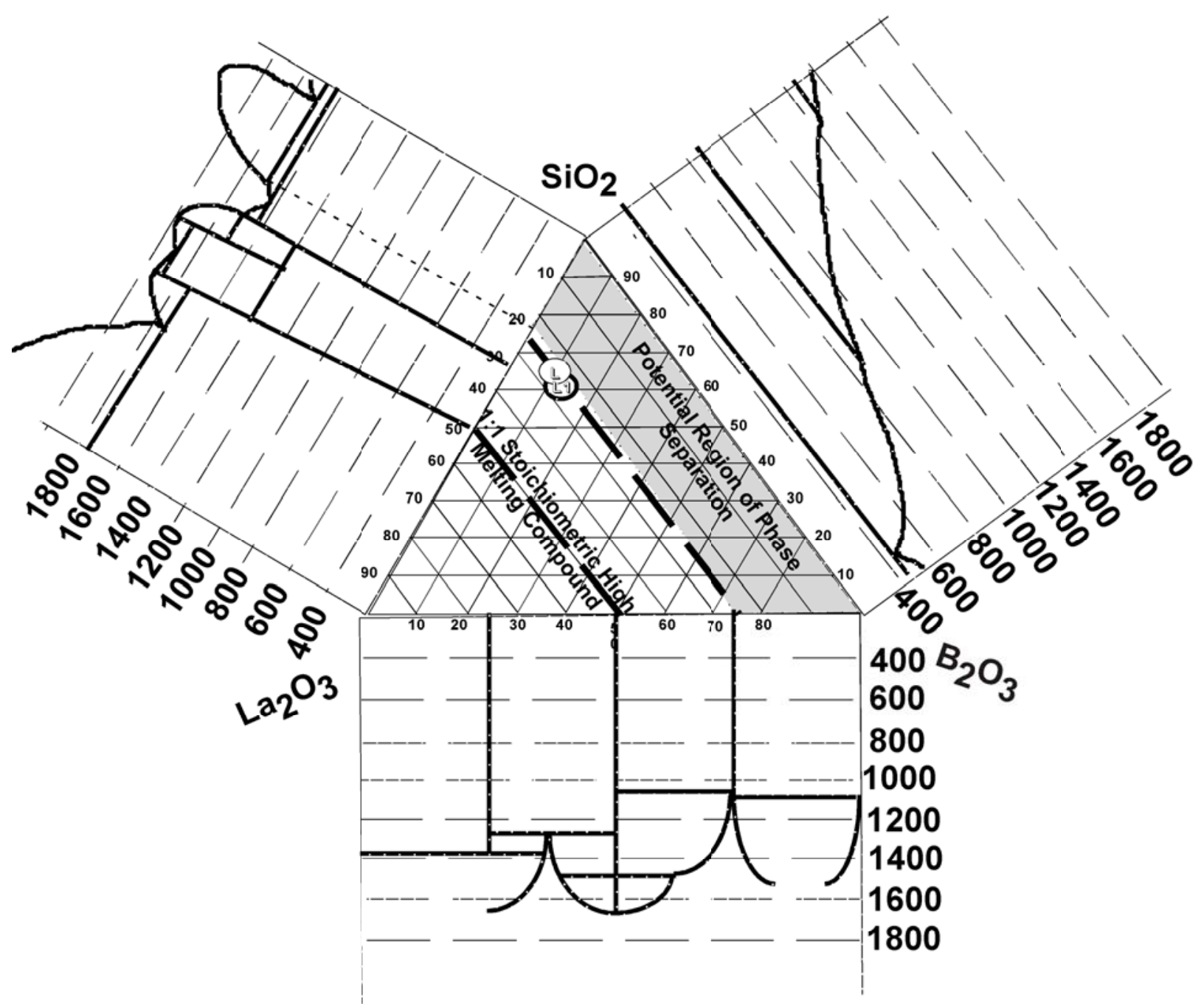

Note that the Loffler glass formulation in the $\mathrm{Ln}_{2} \mathrm{O}_{3}-\mathrm{B}_{2} \mathrm{O}_{3}-\mathrm{SiO}_{2}$ system is indicated in the circle with the letter " $\mathrm{L1}$ " and that if the ternary is generalized to include $\mathrm{SiO}_{2}+\mathrm{Al}_{2} \mathrm{O}_{3}$ at the apex then the Loffler glass formulation in the $\mathrm{Ln}_{2} \mathrm{O}_{3}-\mathrm{B}_{2} \mathrm{O}_{3}-\left(\mathrm{SiO}_{2}+\mathrm{Al}_{2} \mathrm{O}_{3}\right)$ system is indicated as "L".

Figure 5. Ternary Oxide System $\mathrm{La}_{2} \mathrm{O}_{3}-\mathrm{B}_{2} \mathrm{O}_{3}-\mathrm{SiO}_{2}$ generated from the binary oxide systems shown in Figure 1 to Figure 4.

The potential ternary phase relations in the $\mathrm{La}_{2} \mathrm{O}_{3}-\mathrm{B}_{2} \mathrm{O}_{3}-\left(\mathrm{SiO}_{2}+\mathrm{Al}_{2} \mathrm{O}_{3}\right)$ system are shown in Figure 5. The 1:1 $\mathrm{La}_{2} \mathrm{O}_{3}: \mathrm{SiO}_{2}$ stoichiometric compound which melts at $1975^{\circ} \mathrm{C}$ (Figure 1) more than likely forms a high melting temperature ridge in the ternary system (Figure 5) with the $1: 1 \mathrm{La}_{2} \mathrm{O}_{3}: \mathrm{B}_{2} \mathrm{O}_{3}$ stoichiometric compound which melts at $1660^{\circ} \mathrm{C}$ (Figure 3). In the $\mathrm{La}_{2} \mathrm{O}_{3}-\mathrm{B}_{2} \mathrm{O}_{3}-\left(\mathrm{SiO}_{2}+\mathrm{Al}_{2} \mathrm{O} 3\right.$ ) system (Figure 5) compositions in the proximity of this $1: 1$ stoichiometric $\left(\mathrm{La}_{2} \mathrm{O}_{3}-\mathrm{B}_{2} \mathrm{O}_{3}\right):\left(\mathrm{La}_{2} \mathrm{O}_{3}-\mathrm{SiO}_{2}\right)$ ridge will likely have high liquidus temperatures. 
The lowest melting temperature glasses can be formed in the $\mathrm{La}_{2} \mathrm{O}_{3}-\mathrm{B}_{2} \mathrm{O}_{3}-\left(\mathrm{SiO}_{2}+\mathrm{Al}_{2} \mathrm{O}_{3}\right)$ system (Figure 5) along a trough defined by a line joining the eutectic compositions at 1:3 $\mathrm{La}_{2} \mathrm{O}_{3}: \mathrm{SiO}_{2}$ (Figure 1 at 22 mole $\% \mathrm{La}_{2} \mathrm{O}_{3}$ ) and $\sim 1: 3 \mathrm{La}_{2} \mathrm{O}_{3}: 3 \mathrm{~B}_{2} \mathrm{O}_{3}$ (Figure 3 at 25 mole $\% \mathrm{La}_{2} \mathrm{O}_{3}$ ). These eutectics melt at temperatures of $1625^{\circ} \mathrm{C}$ and $\sim 1132-36^{\circ} \mathrm{C}$, respectively. Therefore, along the $\sim 1: 3$ stoichiometric axis shown in Figure 5 compositions higher in $\mathrm{B}_{2} \mathrm{O}_{3}$ will melt at a lower temperature than compositions enriched in $\left(\mathrm{SiO}_{2}+\mathrm{Al}_{2} \mathrm{O}_{3}\right)$.

At compositions with less molar $\mathrm{La}_{2} \mathrm{O}_{3}$ than 22-25 mole $\%$ on Figure 5, the regions of glass-in-glass (2-liquid) phase separation in Figure 1 and Figure 3 more than likely form a continual dome as indicated by the shaded region in Figure 5. The lower stability temperature of the 2 liquid regions in the $\mathrm{La}_{2} \mathrm{O}_{3}$ $\mathrm{SiO}_{2}$ system is $\sim 1700^{\circ} \mathrm{C}$ while the lower stability temperature of the 2-liquid region in the $\mathrm{La}_{2} \mathrm{O}_{3}-\mathrm{B}_{2} \mathrm{O}_{3}$ system is $1136^{\circ} \mathrm{C}$. This is a region of potential phase separation and should be avoided during glass formulation in this system. Even if a homogeneous glass of this composition can be made by rapid pouring and/or quenching, it will be metastable and tend to phase separate and/or crystallize when subjected to annealing and/or subsequent heat treatment.

The molar composition of the Loffler glass from Table 2 is plotted on Figure 5 as a circle with an "L1" designation. This composition omits any contribution from $\mathrm{Al}_{2} \mathrm{O}_{3}$. The solid circle with the $\mathrm{L}$ designation represents the Loffler glass with $\mathrm{Al}_{2} \mathrm{O}_{3}$ considered to be structurally equivalent to $\mathrm{SiO}_{2}$. Both compositions indicate that the high fluidity of the Loffler glass is due to its proximity to the low melting axis in the ternary system that defines the lowest melting eutectics in this system. The presence of $\mathrm{PbO}$ in the Loffler glass further served to lower the eutectic melt temperature.

The molar compositions of the SRNL LaBS glasses from Table 2 (Frit A and Frit B at $9.5 \mathrm{wt} \% \mathrm{PuO}_{2}$ loading) are plotted on Figure 6 assuming that $\mathrm{Al}_{2} \mathrm{O}_{3}$ is structurally equivalent to $\mathrm{SiO}_{2}$ in these glasses. This is done primarily to demonstrate how the substitution of $\mathrm{Al}_{2} \mathrm{O}_{3}$ in the LaBS glass formulations in place of $\mathrm{PbO}^{5,14}$ influenced the LaBS glass homogeneity and solubility. For example, the Loffler glass, the Ramsey $\sim 2 \mathrm{wt} \% \mathrm{ThO}_{2}$ glass, and the Ramsey $17.5 \mathrm{wt} \% \mathrm{ThO}_{2}$ glasses shown on the molar ternary oxide system $\mathrm{La}_{2} \mathrm{O}_{3}-\mathrm{B}_{2} \mathrm{O}_{3}-\left(\mathrm{SiO}_{2}+\mathrm{Al}_{2} \mathrm{O}_{3}\right)$ as stars $(*)$, should all lie in the field of homogeneous glasses as determined in Figure 5 because the glasses were all determined to be homogeneous. Since Loffler states that the lanthanides and the actinides can substitute for each other in the Loffler type glasses, a ternary phase diagram of the $\left(\mathrm{La}_{2} \mathrm{O}_{3}+\mathrm{XO}_{2}\right)-\mathrm{B}_{2} \mathrm{O}_{3}-\left(\mathrm{SiO}_{2}+\mathrm{Al}_{2} \mathrm{O}_{3}\right)$ system (Figure 7), where $\mathrm{XO}_{2} \equiv \mathrm{PuO}_{2}, \mathrm{ThO}_{2}$, $\mathrm{HfO}_{2}$ or $\mathrm{ZrO}_{2}$, was plotted instead. In this combined lanthanide/actinide LaBS system, all three of the homogeneous glasses cited above plot in the region of homogeneous glasses delineated in Figure 5.

Figure 6 and Figure 7 both show that the Meaker base frit $\left(\right.$ no $\left.\operatorname{Ln}_{2} \mathrm{O}_{3}\right)$, also indicated by a star $\left(^{*}\right)$ in these figures, is in the region of inhomogeneity and indeed, the base frit crystallized $\mathrm{AlBO}_{4}$. As Meaker tried to optimize the LaBS compositions with $\mathrm{SrO}$ and $\mathrm{Al}_{2} \mathrm{O}_{3}$, he continually added more $\mathrm{Ln}_{2} \mathrm{O}_{3}$ along the line between his base compositions and the $\mathrm{Ln}_{2} \mathrm{O}_{3}+\mathrm{XO}_{2}$ apex of Figure 7. Meaker's data is indicated with open squares (no $\mathrm{PuO}_{2}$ surrogate), triangles (Pu solubility exceeded), solid circles (glass-in-glass phase separation reported), and solid squares (acceptable glasses). Glasses indicated by open squares in the inhomogeneous region of low $\mathrm{Ln}_{2} \mathrm{O}_{3}+\mathrm{XO}_{2}$ content, were indeed phase separated as were some of the solid squares in this region. Meaker's optimized formulations, Frit A and $\mathrm{B}$ at $9.5 \mathrm{wt} \% \mathrm{PuO}_{2}$ are also shown to be in the region of phase separation. Therefore, frit formulations higher $\operatorname{Ln}_{2} \mathrm{O}_{3}$ appear to be more desirable to avoid phase separation and allow the glass formulations to fall closer to the low melting trough in this system where the Loffler and early SRNL LaBS glass formulations plot. 
Revision 0

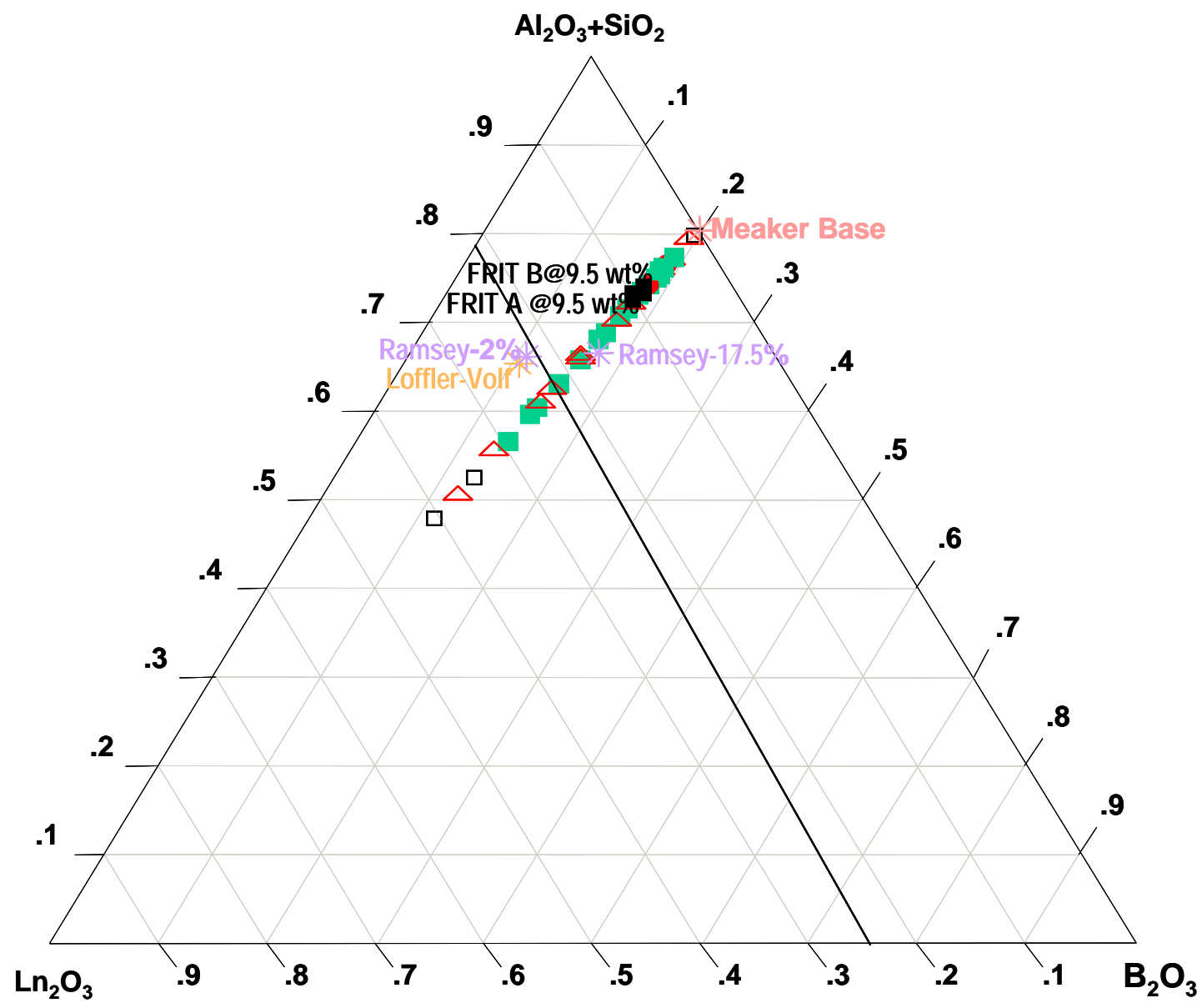

Figure 6. Molar ternary Oxide System $\mathrm{La}_{2} \mathrm{O}_{3}-\mathrm{B}_{2} \mathrm{O}_{3}-\left(\mathrm{SiO}_{2}+\mathrm{Al}_{2} \mathrm{O}_{3}\right)$ with compositions of SRNL LaBS glass formulations tested to date. 


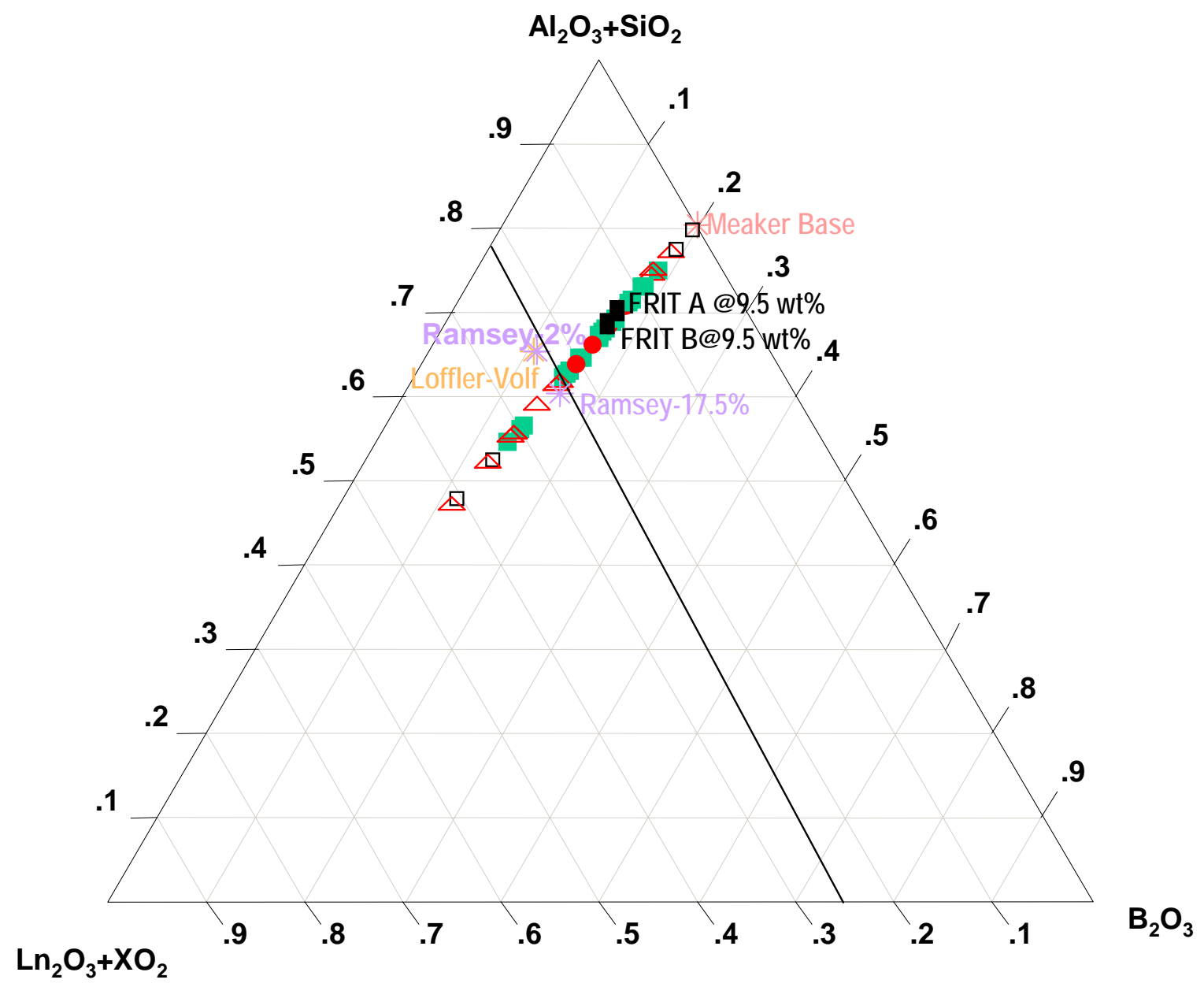

$\mathrm{XO}_{2}=\mathrm{PuO}_{2}, \mathrm{ThO}_{2}, \mathrm{HfO}_{2}$ or $\mathrm{ZrO}_{2}$ and $\mathrm{HfO}_{2}$ and $\mathrm{ZrO}_{2}$ can be either frit components or $\mathrm{PuO}_{2}$ surrogates.

Figure 7. Molar ternary Oxide System $\left(\mathrm{La}_{2} \mathrm{O}_{3}+\mathrm{XO}_{2}\right)-\mathrm{B}_{2} \mathrm{O}_{3}-\left(\mathrm{SiO}_{2}+\mathrm{Al}_{2} \mathrm{O}_{3}\right)$ with compositions of SRNL LaBS glass formulations tested to date. 
Based on this phase equilibrium approach the following composition modifications to the SRNL Frit A and $\mathrm{B} \mathrm{LaBS}$ formulations for $\mathrm{PuO}_{2}$ are recommended:

- $\mathrm{Ln}_{2} \mathrm{O}_{3}$ needs to be added and $\mathrm{Al}_{2} \mathrm{O}_{3}$ and $\mathrm{SiO}_{2}$ content reduced to modify the glass composition so that it is no longer in the range of potential phase separation

- Sufficient $\mathrm{Ln}_{2} \mathrm{O}_{3}$ should be added and $\mathrm{Al}_{2} \mathrm{O}_{3}$ and $\mathrm{SiO}_{2}$ content reduced so that the final glass composition falls on or near the low melting eutectic trough delineated in Figure 5 at $\sim 1: 3$ stoichiometric axis in the $\mathrm{Ln}_{2} \mathrm{O}_{3}-\mathrm{B}_{2} \mathrm{O}_{3}-\left(\mathrm{SiO}_{2}+\mathrm{Al}_{2} \mathrm{O}_{3}\right)$ system

- Compositions lying along the 1:3 stoichiometric axis in the in the $\mathrm{Ln}_{2} \mathrm{O}_{3}-\mathrm{B}_{2} \mathrm{O}_{3}-\left(\mathrm{SiO}_{2}+\mathrm{Al}_{2} \mathrm{O}_{3}\right)$ system (such as the composition shown below) should melt at lower temperatures than the current LaBS formulation and have lower liquidus temperatures:

$$
\begin{aligned}
& 50 \mathrm{SiO}_{2}+\mathrm{Al}_{2} \mathrm{O}_{3} \text { mole } \% \\
& 25-30 \mathrm{Ln}_{2} \mathrm{O}_{3} \text { mole } \% \\
& 20-25 \mathrm{~B}_{2} \mathrm{O}_{3} \text { mole } \%
\end{aligned}
$$

- Mixed $\mathrm{Ln}_{2} \mathrm{O}_{3}$ should continue to be used instead of just $\mathrm{La}_{2} \mathrm{O}_{3}$ since the heat of mixing of the rare earth oxides will effectively lower the melt temperature

- If $20-25 \% \mathrm{~B}_{2} \mathrm{O}_{3}$ is shown to be ineffective then compositions in the range of the original Loffler glass should be formulated as indicated below

$$
\begin{aligned}
& 65 \mathrm{SiO}_{2}+\mathrm{Al}_{2} \mathrm{O}_{3} \text { mole } \% \\
& 27 \mathrm{Ln}_{2} \mathrm{O}_{3} \text { mole } \% \\
& 8 \mathrm{~B}_{2} \mathrm{O}_{3} \text { mole } \%
\end{aligned}
$$

\subsubsection{Additives to Enhance Melting}

The current reference Frit B composition requires a melting temperature of nominally $1500^{\circ} \mathrm{C}$ to ensure dissolution of the constituent frit elements and the plutonium oxide. Glass melting at temperatures in this range is not uncommon in the glass industry; however, melting at elevated temperatures does present a few considerations in processing. The first is volatility from the melt. It is well documented that volatility increases with increasing melt temperature. ${ }^{2,16}$. The rate of corrosion of melter materials of construction is also directly related to melt temperature. ${ }^{17,18}$ Therefore, means to enhance dissolution and lower the melting temperature are of interest in developing an alternative formulation for plutonium vitrification - consistent or in-line with the recommendations as listed above.

Alkali elements are known to lower melting temperatures and melt viscosities through the formation of non-bridging oxygen ions in the glass. ${ }^{2,19}$ However, the addition of alkali elements in borosilicate glasses has been shown to decrease durability. ${ }^{20}$ The impact of iron oxide on durability is typically more neutral in borosilicate glasses yet it can act as a flux to improve melting behavior. ${ }^{14}$ Therefore, the addition of iron oxide is a potential candidate for consideration for alternative LaBS glass compositions. It must be noted that iron readily changes oxidation states depending on the reduction/oxidation state of the melt which must be a consideration for compatibility in a $\mathrm{Pt} / \mathrm{Rh}$ melter system. 


\subsubsection{Increase in Neutron Absorber}

Increasing the neutron absorbers in the glass is also worthy of consideration since the presence of neutron absorbers in the waste form is advantageous for criticality control. Gadolinium oxide and hafnium oxide are present in the baseline Frit B composition and both are known to be excellent neutron absorbers. ${ }^{21}$ Compositions with high lanthanide contents could result in increased Gd concentrations. Increasing the hafnium oxide level in the glass may be beneficial because Hf has been shown to have a low aqueous solubility. ${ }^{22}$ 
WSRC-TR-2006-00031

Revision 0

This page intentionally left blank. 


\subsection{EXPERIMENTAL PROCEDURES}

\subsubsection{Simulant Glass Fabrication}

Table 3 and Table 4 summarize the baseline frit (Frit B) and 9 initial alternative compositions on a mass $\%$ and $\mathrm{mol} \%$ basis, respectively. As previously discussed, the baseline frit composition (Frit B) has demonstrated relatively high solubility for plutonium and uranium (individually and combination) and exhibited excellent durability (as defined by the PCT). As discussed in Section 2.2, the strategy to support alternative frit development efforts for the actinide bearing glasses were primarily focused on compositional adjustments that could lower the melt temperature (or liquidus temperature) while maintaining or improving glass homogeneity (with respect to Pu solubility) and durability (or performance). Specifically, the compositional adjustments were based on:

Sufficient $\mathrm{Ln}_{2} \mathrm{O}_{3}$ should be added and $\mathrm{Al}_{2} \mathrm{O}_{3}$ and $\mathrm{SiO}_{2}$ content reduced to avoid potential phase separation and to target the low melting eutectic trough delineated in the $\mathrm{Ln}_{2} \mathrm{O}_{3}-\mathrm{B}_{2} \mathrm{O}_{3}$ $\left(\mathrm{SiO}_{2}+\mathrm{Al}_{2} \mathrm{O}_{3}\right)$ system.

o Specifically targeting the $1: 3$ stoichiometric axis

o $50 \mathrm{~mol} \% \mathrm{SiO}_{2}+\mathrm{Al}_{2} \mathrm{O}_{3}, 25-30 \mathrm{~mol} \% \mathrm{Ln}_{2} \mathrm{O}_{3}, 20-25 \mathrm{~mol} \% \mathrm{~B}_{2} \mathrm{O}_{3}$

Mixed $\mathrm{Ln}_{2} \mathrm{O}_{3}$ should be used instead of $\mathrm{La}_{2} \mathrm{O}_{3}$ since the heat of mixing of the rare earth oxides will lower the melt temperatures.

This first two recommendations lead to compositional changes reflected in High $\mathrm{Ln}_{2} \mathrm{O}_{3} \# 1-$ High $\mathrm{Ln}_{2} \mathrm{O}_{3} \# 4$ which target $~ 52-54 \mathrm{~mol} \% \mathrm{SiO}_{2}+\mathrm{Al}_{2} \mathrm{O}_{3}$ (down from $\sim 70 \mathrm{~mol} \%$ in Frit $\mathrm{B}$ ), $20-22 \mathrm{~mol} \% \mathrm{Ln}_{2} \mathrm{O}_{3}$ (up from $\sim 12 \mathrm{~mol} \%$ in Frit B), and $\mathrm{B}_{2} \mathrm{O}_{3}$ concentrations of approximately $20-22 \mathrm{~mol} \%$ (up from $\sim 16 \mathrm{~mol} \%$ in Frit B). A primary difference between the four alternative glasses is the relative concentrations (or distribution) of $\mathrm{Gd}_{2} \mathrm{O}_{3}, \mathrm{HfO}_{2}$, $\mathrm{La}_{2} \mathrm{O}_{3}$, and $\mathrm{Nd}_{2} \mathrm{O}_{3}$.

If $20-25 \mathrm{~mol}_{\mathrm{O}} \mathrm{B}_{2} \mathrm{O}_{3}$ is shown to be effective, then compositions in the range of the original Loffler glass should be formulated.

o $65 \mathrm{~mol} \% \mathrm{SiO}_{2}+\mathrm{Al}_{2} \mathrm{O}_{3}, 27 \mathrm{~mol} \% \mathrm{Ln}_{2} \mathrm{O}_{3}$, and $8 \mathrm{~mol} \% \mathrm{~B}_{2} \mathrm{O}_{3}$

The compositional adjustments made based on this recommendation are expressed through the Loffler \#1 and Loffler \#2 frit compositions. The mol\% $\mathrm{SiO}_{2}+\mathrm{Al}_{2} \mathrm{O}_{3}$ in Loffler \#1 and Loffler $\# 2$ are $\sim 64 \%$ and $\sim 67.5 \%$, respectively.

$>\mathrm{Fe}_{2} \mathrm{O}_{3}$ should be used as an additional flux (as long as it is compatible with the melter materials of construction).

This recommendation led to the compositional adjustments made in $\mathrm{High} \mathrm{Fe}_{2} \mathrm{O}_{3} \# 1$ and High $\mathrm{Fe}_{2} \mathrm{O}_{3} \# 2$ glasses.

Additional neutron absorber concentrations should be added to improve criticality performance. $\mathrm{HfO}_{2}$ is especially attractive due to its relatively low aqueous solubility.

This recommendation led to the compositional adjustments made in the $\mathrm{High}_{\mathrm{HfO}_{2}}$ glass. 
As indicated, the compositional adjustments were primarily focused on lowering the melt temperature (or liquidus temperature) while maintaining or improving glass homogeneity (with respect to Pu solubility) and durability (or performance). The final compositional adjustment was solely based on increasing neutron absorber content.

Table 3. Target Composition of Baseline and Initial Alternative Frit Compositions (mass\%).

\begin{tabular}{|c|c|c|c|c|c|c|c|c|c|c|}
\hline Oxide & Frit B & $\begin{array}{c}\text { High } \\
\operatorname{Ln}_{2} \mathrm{O}_{3} \# 1\end{array}$ & $\begin{array}{c}\text { High } \\
\operatorname{Ln}_{2} \mathrm{O}_{3} \# 2\end{array}$ & $\begin{array}{c}\text { High } \\
\operatorname{Ln}_{2} \mathrm{O}_{3} \# 3\end{array}$ & $\begin{array}{c}\text { High } \\
\operatorname{Ln}_{2} \mathrm{O}_{3} \# 4\end{array}$ & $\begin{array}{c}\text { Loffler } \\
\# 1\end{array}$ & $\begin{array}{c}\text { Loffler } \\
\# 2\end{array}$ & $\begin{array}{l}\text { High } \\
\mathrm{HfO}_{2}\end{array}$ & $\begin{array}{c}\text { High } \\
\mathrm{Fe}_{2} \mathrm{O}_{3} \# 1\end{array}$ & $\begin{array}{c}\text { High } \\
\mathrm{Fe}_{2} \mathrm{O}_{3} \# 2\end{array}$ \\
\hline $\mathrm{Al}_{2} \mathrm{O}_{3}$ & 21.3 & 12 & 10 & 12 & 10 & 13 & 15 & 21.3 & 21.3 & 15 \\
\hline $\mathrm{B}_{2} \mathrm{O}_{3}$ & 11.6 & 13 & 13 & 13 & 13 & 4.5 & 5 & 11.6 & 11.6 & 13 \\
\hline $\mathrm{Gd}_{2} \mathrm{O}_{3}$ & 12.8 & 13.5 & 13.5 & 19.5 & 23.5 & 15 & 12 & 9.8 & 12.8 & 12.8 \\
\hline $\mathrm{HfO}_{2}$ & 6.6 & 15 & 6 & 9 & 6 & 15 & 11.5 & 9.6 & 6.6 & 6 \\
\hline $\mathrm{La}_{2} \mathrm{O}_{3}$ & 8.1 & 12 & 20 & 12 & 10 & 15 & 15 & 8.1 & 8.1 & 10 \\
\hline $\mathrm{Nd}_{2} \mathrm{O}_{3}$ & 8.2 & 12 & 15 & 12 & 15 & 15 & 14 & 8.2 & 8.2 & 8.2 \\
\hline $\mathrm{SiO}_{2}$ & 28.9 & 20 & 20 & 20 & 20 & 22 & 25 & 28.9 & 28.9 & 25 \\
\hline $\mathrm{SrO}$ & 2.5 & 2.5 & 2.5 & 2.5 & 2.5 & 0.5 & 2.5 & 2.5 & 0 & 0 \\
\hline $\mathrm{Fe}_{2} \mathrm{O}_{3}$ & 0 & 0 & 0 & 0 & 0 & 0 & 0 & 0 & 2.5 & 10 \\
\hline Total & 100 & 100 & 100 & 100 & 100 & 100 & 100 & 100 & 100 & 100 \\
\hline
\end{tabular}

Table 4. Target Composition of Baseline and Initial Alternative Frit Compositions (mol \%).

\begin{tabular}{|c|c|c|c|c|c|c|c|c|c|c|}
\hline Oxide & $\begin{array}{c}\text { Frit } \\
\text { B }\end{array}$ & $\begin{array}{c}\text { High } \\
\mathbf{L n}_{2} \mathbf{O}_{3} \\
\# 1\end{array}$ & $\begin{array}{c}\text { High } \\
\mathbf{L n}_{2} \mathrm{O}_{3} \\
\# 2\end{array}$ & $\begin{array}{c}\text { High } \\
\mathbf{L n}_{2} \mathbf{O}_{3} \\
\# 3\end{array}$ & $\begin{array}{c}\text { High } \\
\mathrm{Ln}_{2} \mathrm{O}_{3} \\
\# 4\end{array}$ & $\begin{array}{c}\text { Loffler } \\
\# 1\end{array}$ & $\begin{array}{c}\text { Loffler } \\
\# 2\end{array}$ & $\begin{array}{l}\text { High } \\
\text { HfO }_{2}\end{array}$ & $\begin{array}{c}\text { High } \\
\mathrm{Fe}_{2} \mathrm{O}_{3} \\
\# 1\end{array}$ & $\begin{array}{c}\text { High } \\
\mathrm{Fe}_{2} \mathrm{O}_{3} \\
\# 2\end{array}$ \\
\hline $\mathrm{Al}_{2} \mathrm{O}_{3}$ & 20.96 & 13.97 & 12.06 & 14.17 & 12.10 & 16.64 & 17.63 & 20.84 & 21.14 & 15.79 \\
\hline $\mathrm{B}_{2} \mathrm{O}_{3}$ & 16.72 & 22.17 & 22.95 & 22.48 & 23.04 & 8.43 & 8.61 & 16.62 & 16.86 & 20.05 \\
\hline $\mathrm{Gd}_{2} \mathrm{O}_{3}$ & 3.54 & 4.42 & 4.58 & 6.48 & 8.00 & 5.40 & 3.97 & 2.70 & 3.57 & 3.79 \\
\hline $\mathrm{HfO}_{2}$ & 3.15 & 8.46 & 3.50 & 5.15 & 3.52 & 9.30 & 6.55 & 4.55 & 3.17 & 3.06 \\
\hline $\mathrm{La}_{2} \mathrm{O}_{3}$ & 2.49 & 4.37 & 7.55 & 4.43 & 3.79 & 6.01 & 5.52 & 2.48 & 2.52 & 3.30 \\
\hline $\mathrm{Nd}_{2} \mathrm{O}_{3}$ & 2.45 & 4.23 & 5.48 & 4.29 & 5.50 & 5.82 & 4.99 & 2.43 & 2.47 & 2.62 \\
\hline $\mathrm{SiO}_{2}$ & 48.27 & 39.52 & 40.92 & 40.08 & 41.08 & 47.78 & 49.86 & 47.98 & 48.68 & 44.67 \\
\hline $\mathrm{SrO}$ & 2.42 & 2.86 & 2.97 & 2.90 & 2.98 & 0.63 & 2.89 & 2.41 & 0.00 & 0.00 \\
\hline $\mathrm{Fe}_{2} \mathrm{O}_{3}$ & 0.00 & 0.00 & 0.00 & 0.00 & 0.00 & 0.00 & 0.00 & 0.00 & 1.58 & 6.72 \\
\hline Total & 100 & 100 & 100 & 100 & 100 & 100 & 100 & 100 & 100 & 100 \\
\hline
\end{tabular}


Each simulated Pu-glass was prepared from the proper proportions of reagent-grade metal oxides and $\mathrm{H}_{3} \mathrm{BO}_{3}$ in 100 -g batches using $\mathrm{HfO}_{2}$ as a $\mathrm{PuO}_{2}$ surrogate. Specifically, each alternative simulated glass targeted 10 mass $\% \mathrm{HfO}_{2}$ (note that this is in addition to the $\mathrm{HfO}_{2}$ present in the nominal frit composition as listed in Tables 3 and 4). The raw materials were thoroughly mixed and placed into a 95\% Platinum/ $5 \%$ Rhodium $250-\mathrm{mL}$ crucible. The batch was placed into a high-temperature furnace at the target melt temperature of $1500^{\circ} \mathrm{C}$. After an isothermal hold at $1500^{\circ} \mathrm{C}$ for $2.0 \mathrm{~h}$, the crucible was removed, and the glass was poured onto a clean stainless steel plate and allowed to air cool (quench). The glass pour patty was used as a sampling stock for the various property measurements (i.e., chemical composition, durability, and heat treatments).

\subsubsection{Plutonium Glass Fabrication}

Based on the results of the surrogate testing, a composition was selected for plutonium glass fabrication. The composition selected was the High $\mathrm{Ln}_{2} \mathrm{O}_{3} \# 2$ Mod (as shown in Tables 3-1 and 3-2). It should be noted that the nomenclature used during the "feasibility" surrogate testing was changed after selecting this frit composition for radioactive testing. The High $\mathrm{Ln}_{2} \mathrm{O}_{3} \# 2 \mathrm{Mod}$ frit was subsequently renamed Frit X. To facilitate fabrication of the plutonium glass, frit was first prepared in a non-radioactive environment. The frit was prepared by mixing reagent grade chemicals in the proportion for the High $\mathrm{Ln}_{2} \mathrm{O}_{3} \# 2 \mathrm{Mod}$ (Table 3) scaled to produce a $100 \mathrm{~g}$ batch of frit. Oxide chemicals were used for all components except for boron. Boric acid was used to provide the necessary $\mathrm{B}_{2} \mathrm{O}_{3}$ content in the frit. The frit batch was melted at $1500^{\circ} \mathrm{C}$ in $\mathrm{Pt} / \mathrm{Rh}$ crucibles. After nominally two hours at temperature, the crucible was removed from the furnace at temperature and the molten glass poured on a steel plate. The "cullet" pieces were collected for subsequent grinding. The cullet was ground in an automated agate milled and sieved to collect the fraction that was -325 mesh $(<45 \mu \mathrm{m})$.

After the frit was melted and ground, a sample was analyzed using Inductively Coupled Plasma - Atomic Emission Spectroscopy (ICP-AES) to verify the composition. The sample was prepared by a peroxide fusion $\left(\mathrm{Na}_{2} \mathrm{O}_{2} / \mathrm{NaOH} / \mathrm{HCl}\right)$. The glass sample was prepared in duplicate and was analyzed by ICP-AES to measure the constitutive frit elements.

The plutonium oxide material was obtained from personnel in the Actinide Technology Section of the Savannah River National Laboratory (SRNL). Before using the $\mathrm{PuO}_{2}$ to fabricate glass, the isotopic content and purity of the material were determined. A sample of the $\mathrm{PuO}_{2}$ was dissolved in a mixture of 8 $\mathrm{M} \mathrm{HNO}_{3} / 0.05 \mathrm{M} \mathrm{KF}$ to facilitate the analyses. Gamma scan and liquid scintillation counting were used to determine the actinide isotopic distribution. To assess for the presence of any impurities, ICP-ES was utilized.

Once the composition of the frit was verified via chemical analysis, the frit was weighed into the appropriate amount to produce $30 \mathrm{~g}$ with a target $\mathrm{PuO}_{2}$ loading of $9.5 \mathrm{wt} \%$. The frit was placed in a plastic bottle for introduction into the SRNL Shielded Cells facility. In the Shielded Cells, the appropriate quantity of $\mathrm{PuO}_{2}$ was weighed and added to the bottle containing the frit. The bottle was capped and the mixture manually mixed for a few minutes using the rotation afforded by the manipulator arm. The mixture of frit and $\mathrm{PuO}_{2}$ was placed in a $\mathrm{Pt} / \mathrm{Rh}$ crucible for melting. ${ }^{\mathrm{d}}$

\footnotetext{
${ }^{\mathrm{d}}$ Previous testing demonstrated that co-grinding the $\mathrm{PuO}_{2}$ and the frit and manual stirring of the melt enhanced $\mathrm{PuO}$ dissolution in the melt. These techniques could not be used in the current fabrication facility.
} 
The $\mathrm{Pt} / \mathrm{Rh}$ crucible was placed in a high temperature elevator furnace and the furnace was ramped to the melting temperature of $1500^{\circ} \mathrm{C}$ using a ramp rate of $10^{\circ} \mathrm{C} /$ minute. The melt was held at temperature for 4 hours and promptly removed from the furnace and quenched in a pan of water. Upon cooling, the glass was manually removed from the crucible by "hammering" the crucible. In this manner nominally $99 \%$ of the glass was recovered from the crucible. In an effort to enhance homogenization of the glass, the glass was melted a second time. The glass was melted using the same methodology used for the initial melt.

\subsubsection{Glass Characterization}

\subsubsection{Compositional Analysis}

To confirm that the "as-fabricated" glasses corresponded to the defined target compositions, a representative sample from each glass was analyzed. The surrogate glass samples were prepared in duplicate using a sodium peroxide/sodium hydroxide $\left(\mathrm{Na}_{2} \mathrm{O}_{2} / \mathrm{NaOH}\right)$ fusion with a $\mathrm{HCl}$ uptake. The peroxide fusion dissolution allows for the analysis of all elemental concentrations of interest (A1, B, Ce, Gd, Hf, La, Nd, Si, Sr, and Fe). The dissolutions were analyzed by ICP-AES.

\subsubsection{Glass Density}

Room temperature density for select simulated $\mathrm{Pu}$ glasses was measured by buoyancy (Archimedes method) in water. To support the measurements, an approximate five gram monolithic sample was selected from each pour patty.

\subsubsection{SEM and XRD Analyses}

Scanning Electron Microscopy coupled with Energy Dispersive Spectroscopy (SEM/EDS) and X-ray Diffraction (XRD) were used to assess the homogeneity of both the simulant and Pu containing glasses. Specifically, the analyses were used to examine for the presence of crystalline species and other heterogeneities that may be in the glass. The crystalline species could result from undissolved matter in the glass or phases that crystallized from the glass. The latter was of specific interest for the isothermal heat treatment tests that were conducted (see Section 3.1.5). Analyses were conducted on both shard samples and samples that were ground, sieved and washed according to the protocol used for the PCT. The samples were placed on an aluminum stub to facilitate analysis in the SEM. Crushed glass samples were analyzed by XRD.

\subsubsection{Product Consistency Testing}

The PCT was performed in triplicate on each simulated Pu-glass to assess chemical durability using technical procedure "Standard Test Methods for Determining Chemical Durability of Nuclear Waste Glasses: The Product Consistency Test (PCT)" (ASTM 2002). Also included in this experimental test matrix was the EA glass, ${ }^{11}$ the Approved Reference Material (ARM) glass, and blanks from the sample cleaning batch. Samples were ground, washed, and prepared according to procedure. ${ }^{11}$ Fifteen milliliters of Type I American Society for Testing and Materials (ASTM) water were added to $\sim 1.5 \mathrm{~g}$ of glass in stainless steel vessels. Due to significant density difference of the simulated Pu glasses and "typical" DWPF glasses, an adjustment to the mass of each glass was made based on the measured density to maintain a "constant" surface area (of glass) to volume (of solution) ratio. Maintaining a constant ratio allows for a direct comparison among the various glasses with respect to durability. Table 5 summarizes the mass of each glass used to support the PCT assessments. The vessels were closed, sealed, and placed in an oven at $90 \pm 2^{\circ} \mathrm{C}$ where the samples were maintained for 7 days. The resulting solutions (once cooled) were sampled (filtered and acidified), labeled, and analyzed. Normalized release rates were calculated based on targeted compositions using the average of the logs of the leachate concentrations. 
Table 5. Mass of Glass Used to Support PCT Assessments of Surrogate Glasses.

\begin{tabular}{|c|c|c|}
\hline Glass & $\begin{array}{c}\text { Mass of Glass } \\
\text { (g) }\end{array}$ & $\begin{array}{c}\text { Volume of } \mathbf{H}_{\mathbf{2}} \mathbf{O} \\
(\mathbf{m L} \mathbf{)}\end{array}$ \\
\hline EA & 1.5 & 15 \\
\hline Frit B & 1.99 & 15 \\
\hline $\mathrm{Fe}_{2} \mathrm{O}_{3}$ Based \#2 & 2.12 & 15 \\
\hline $\mathrm{High} \mathrm{Ln}_{2} \mathrm{O}_{3} \# 2 \mathrm{Mod}$ & 2.39 & 15 \\
\hline $\mathrm{High} \mathrm{Ln}_{2} \mathrm{O}_{3} \# 4 \mathrm{Mod}$ & 2.42 & 15 \\
\hline
\end{tabular}

\subsubsection{Isothermal Heat Treatments}

During melter testing with the Frit B composition to support the macroscopic surface area determination task, it became evident that the Frit B formulation was susceptible to crystallization at temperatures that could be expected in the Cylindrical Induction Melter (CIM). Therefore, it was necessary to perform testing to benchmark the crystallization behavior of alternative glass compositions to the reference Frit B composition. Moreover, when it was discovered that controlled crystallization may provide the potential to form a plutonium/hafnium phase in the glass, isothermal testing was of additional interest. This latter possibility may be advantageous with respect to minimizing the separation between neutron absorbers and fissile materials.

For simulant glasses, the samples were placed in Pt/Rh crucibles and isothermally heat treated in a high temperature furnace. The furnace was set for the prescribed isothermal temperature and the glass samples were held at temperature for 24 hours. After 24 hours at temperature, the glass was removed from the furnace and allowed to air cool. Due to failure of the high temperature furnace located in the Shielded Cells facility, only limited isothermal heat treatment testing could be performed on the Pu glass. For the $\mathrm{Pu}$ glass, a small muffle furnace with a maximum operating temperature of $1200^{\circ} \mathrm{C}$ was utilized for testing in a radiological hood. Isothermal thermal treatment of the Pu containing glass was conducted on glass shards placed in a Pt/Rh boat. These tests were conducted for 10 hours at the prescribed temperature. ${ }^{\mathrm{e}}$ After 10 hours at temperature, the furnace door was opened to allow the furnace to cool several hundred degrees before the furnace was shut down to allow the glass to cool in the furnace.

\footnotetext{
${ }^{\mathrm{e}}$ Since the furnace was being operated near the upper temperature limit, it was felt that testing for 10 hours with frequent monitoring of the furnace was prudent. This duration was deemed adequate for this scoping test.
} 


\subsection{RESULTS}

\subsection{Simulant Glass Visual Observations}

Table 6 summarizes the visual observations of the "as-fabricated" simulated Pu glasses (i.e., glasses produced by coupling the nominal frit compositions with 10 mass $\% \mathrm{HfO}_{2}$ as the $\mathrm{PuO}_{2}$ surrogate). Visual observations were recorded on the pour patty surface as well as the cross section of the pour patty (referred to as the "bulk"). In addition, visual inspection of the glass remaining in the crucible after pouring (referred to as "residual crucible" glass) was made and documented. Although no formal measurement of viscosity was made, visual observations during pouring suggested that the high lanthanide compositions had extremely low viscosities. This may allow for lower melt temperatures.

Prior to discussing the results, a few words regarding the terminology used in Table 6 are warranted. The use of "homogeneous" for visual observations indicates that the sample was classified as a single-phase system (i.e., no evidence of crystallization, undissolved solids, or other inhomogeneities). Glasses characterized by the term "undissolved solids" refers to unreacted or undissolved material (presumably an oxide(s) used as a raw material source that did not go into solution) visually evident in either the pour patty, the residual crucible glass, or both. Other terms used to describe visual characteristics of select glasses include: swirls, coatings, and streaks. These latter descriptors refer to different types of inhomogeneities observed but typically are related to undissolved solids in the glass.

Visual observations of the Frit B glass indicated the presence of undissolved solids in both the pour patty as well as the residual crucible glass. White streaks were also observed in the pour patty which possibly resulted from the undissolved solids being "smeared" as the glass was poured. The undissolved material was $\mathrm{HfO}_{2}$ - suggesting that the solubility limit had been exceeded under the melt conditions. Based on this observation, a second melt was performed targeting the Frit B glass composition. The primary difference for this second melt was that the glass was batched and melted for 2 hours and poured. After the initial pour, the glass was ground in a tungsten carbide grinder, and remelted at $1500^{\circ} \mathrm{C}$ for 1 hour to evaluate $\mathrm{HfO}_{2}$ solubility or homogeneity. Although the pour patty and residual crucible glass were "more homogeneous" than the original Frit B melt, undissolved solids and swirls were still observed (as noted in Table 6). 
Table 6. Visual Observations of the "As Fabricated” Baseline and Alternative Pu-Glasses

\begin{tabular}{|c|c|}
\hline GLASS ID & VISUAL OBSERVATIONS \\
\hline Frit B & $\begin{array}{l}\text { Undissolved solids in both residual crucible glass and pour } \\
\text { patty, "white" streaks in pour patty }\end{array}$ \\
\hline $\begin{array}{c}\text { Frit B } \\
\text { (rebatched/remelted) }\end{array}$ & $\begin{array}{l}\text { Resulting glass still contains some "white" swirls. A little } \\
\text { better than the initial Frit B (as noted above) but still } \\
\text { undissolved solids and/or swirls present. }\end{array}$ \\
\hline High $\mathrm{Ln}_{2} \mathrm{O}_{3} \# 1$ & $\begin{array}{l}\text { Both residual crucible glass and pour patty contained } \\
\text { significant undissolved solids (presumably } \mathrm{HfO}_{2} \text { ) }\end{array}$ \\
\hline High $\mathrm{Ln}_{2} \mathrm{O}_{3} \# 2$ & $\begin{array}{l}\text { Pour patty and residual crucible glass appeared "single } \\
\text { phase" - no undissolved solid noted. Nice "purple" } \\
\text { transparent glass. }\end{array}$ \\
\hline High $\mathrm{Ln}_{2} \mathrm{O}_{3} \# 3$ & $\begin{array}{l}\text { Pour patty and residual crucible glass contained } \\
\text { undissolved solids. Visually appeared "cleaner" than } \\
\text { High } \mathrm{Ln}_{2} \mathrm{O}_{3} \# 1 \text {. }\end{array}$ \\
\hline High $\mathrm{Ln}_{2} \mathrm{O}_{3} \# 4$ & $\begin{array}{l}\text { Pour patty and residual crucible glass appeared "single } \\
\text { phase" - no undissolved solid noted. Nice "purple" } \\
\text { transparent glass. }\end{array}$ \\
\hline Loffler \#1 & $\begin{array}{l}\text { Appeared almost "glass-ceramic"-like. Very } \\
\text { inhomogeneous. }\end{array}$ \\
\hline Loffler \#2 & $\begin{array}{l}\text { Appeared almost "glass-ceramic"-like. Very } \\
\text { inhomogeneous. }\end{array}$ \\
\hline High $\mathrm{HfO}_{2}$ & $\begin{array}{l}\text { Appeared almost "glass-ceramic"-like. Very } \\
\text { inhomogeneous. }\end{array}$ \\
\hline $\mathrm{High} \mathrm{Fe}_{2} \mathrm{O}_{3} \# 1$ & $\begin{array}{l}\text { Undissolved solids in pour patty and residual crucible } \\
\text { glass (much darker glass due to } \mathrm{Fe}_{2} \mathrm{O}_{3} \text { ). "White" solids } \\
\text { very apparent throughout. }\end{array}$ \\
\hline High $\mathrm{Fe}_{2} \mathrm{O}_{3} \# 2$ & $\begin{array}{l}\text { Glass did not appear to contain undissolved solids. Dark } \\
\text { brown/black glass due to } \mathrm{Fe}_{2} \mathrm{O}_{3} \text {. The surface of the pour } \\
\text { patty was characterized by a "matte" (or crystalline-like) } \\
\text { finish - very similar to DWPF type glasses that push } \\
\text { toward higher waste loadings yielding devitrification on } \\
\text { surface. Cross section of pour patty appeared to be clean } \\
\text { or glassy. }\end{array}$ \\
\hline
\end{tabular}

Other alternative glasses which resulted in inhomogeneous glass systems included high $\mathrm{Ln}_{2} \mathrm{O}_{3} \# 1$, high $\mathrm{Ln}_{2} \mathrm{O}_{3} \# 3$, both Loffler compositions, the high $\mathrm{HfO}_{2}$ glass, and the high $\mathrm{Fe}_{2} \mathrm{O}_{3} \# 1$ glass. Based on visual observations, the High $\mathrm{Ln}_{2} \mathrm{O}_{3} \# 3$ was "cleaner" than High $\mathrm{Ln}_{2} \mathrm{O}_{3} \# 1$ however, both contained undissolved solids (presumably $\mathrm{HfO}_{2}$ ). Relative to the Frit B glass, the compositional adjustments for these two glasses were "in the right direction" (lower $\mathrm{Al}_{2} \mathrm{O}_{3}$ and higher mixed $\mathrm{Ln}_{2} \mathrm{O}_{3}$ concentrations) to lower the melt temperature (or liquidus temperature) while maintaining or improving glass homogeneity (with respect to $\mathrm{Pu}$ solubility). 
Both Loffler glasses (Loffler \#1 and Loffler \#2) as well as the high $\mathrm{HfO}_{2}$ glass were characterized as inhomogeneous as the glasses appeared very opalescent (almost glass-ceramic like) suggesting either amorphous phase separation and/or undissolved solids. The low $\mathrm{B}_{2} \mathrm{O}_{3}$ content of these glasses coupled with the relatively low $\mathrm{Al}_{2} \mathrm{O}_{3}+\mathrm{SiO}_{2}$ concentration appears to a compositional region to be avoided.

The high $\mathrm{Fe}_{2} \mathrm{O}_{3} \# 1$ glass was also characterized by undissolved solids throughout the pour patty as well as the residual crucible glass. The undissolved solids were visually "white" suggesting incomplete dissolution of $\mathrm{HfO}_{2}$. The high $\mathrm{Fe}_{2} \mathrm{O}_{3} \# 2$ glass did not contain undissolved solids in either the pour patty or the residual crucible glass - suggesting that a significant increase in the $\mathrm{Fe}_{2} \mathrm{O}_{3}$ content of the frit could result in relative high solubility for $\mathrm{HfO}_{2}\left(\right.$ or $\left.\mathrm{PuO}_{2}\right)$. However, the surface of the pour patty was characterized by a "dull matte" texture. The surface was very similar to simulated high level waste glasses that target relatively high waste loadings resulting in surface devitrification of spinels. The surface coating is not considered to be a technical show-stopper.

Visual observations of the High $\mathrm{Ln}_{2} \mathrm{O}_{3} \# 2$ and High $\mathrm{Ln}_{2} \mathrm{O}_{3} \# 4$ glasses indicated both glasses were very homogeneous with no signs of undissolved solids, swirls, or textured coatings. Both glasses were characterized as a "nice purple, transparent glass." These two High $\mathrm{Ln}_{2} \mathrm{O}_{3}$ glasses were based on the compositional direction of adding sufficient $\mathrm{Ln}_{2} \mathrm{O}_{3}$ while lowering the $\mathrm{Al}_{2} \mathrm{O}_{3}$ and $\mathrm{SiO}_{2}$ content to avoid potential phase separation and to target the low melting eutectic trough delineated in the $\mathrm{Ln}_{2} \mathrm{O}_{3}-\mathrm{B}_{2} \mathrm{O}_{3}$ $\left(\mathrm{SiO}_{2}+\mathrm{Al}_{2} \mathrm{O}_{3}\right)$ system. Given the High $\mathrm{Ln}_{2} \mathrm{O}_{3} \# 1$ and $\# 3$ glasses were based on this same theory, the primary difference between the "homogeneous" and "inhomogeneous" glasses was the partitioning of the various rare earths. In general, the High $\mathrm{Ln}_{2} \mathrm{O}_{3} \# 2$ and $\# 4$ glasses had slightly lower $\mathrm{Al}_{2} \mathrm{O}_{3}$ concentrations as well as lower $\mathrm{HfO}_{2}$ contents than their counterpart high $\mathrm{Ln}_{2} \mathrm{O}_{3}$ "inhomogeneous" glasses.

Based on these initial melts and visual observations, two additional frit compositions were developed based on the High $\mathrm{Ln}_{2} \mathrm{O}_{3} \# 2$ and High $\mathrm{Ln}_{2} \mathrm{O}_{3} \# 4$ glasses. These frit compositions (referred to as High $\mathrm{Ln}_{2} \mathrm{O}_{3} \# 2$ Mod and High $\mathrm{Ln}_{2} \mathrm{O}_{3} \# 4$ Mod) are listed in Table 7 (both mass $\%$ and mol\% are shown). The compositional changes to these two "modified" glasses are very minimal as compared to their counterparts. Specifically, the primary difference between the two modified glasses is a $1 \%$ increase in the $\mathrm{HfO}_{2}$ content with the counter reduction coming out of $\mathrm{La}_{2} \mathrm{O}_{3}$ and $\mathrm{Gd}_{2} \mathrm{O}_{3}$ for the High $\mathrm{Ln}_{2} \mathrm{O}_{3} \# 2$ Mod and High $\mathrm{Ln}_{2} \mathrm{O}_{3} \# 4$ Mod glasses, respectively. The increase in $\mathrm{HfO}_{2}$ was driven by the desire to have as much (if not more) contribution of $\mathrm{HfO}_{2}$ as a neutron absorber as Frit $\mathrm{B}$ without compromising product quality or homogeneity.

Table 7. Target Composition of Baseline and Initial Alternative Frit Compositions (mass \%)

\begin{tabular}{|c|c|c|c|c|}
\hline & \multicolumn{2}{|c|}{ High Ln $\mathbf{~ O}_{3}$ \#2 Mod } & \multicolumn{2}{c|}{ High Ln $\mathbf{~ O}_{3}$ \#4 Mod } \\
\hline Oxide & Mass \% & Mol\% & Mass\% & Mol\% \\
\hline $\mathrm{Al}_{2} \mathrm{O}_{3}$ & 10.00 & 12.03 & 10.00 & 12.07 \\
\hline $\mathrm{B}_{2} \mathrm{O}_{3}$ & 13.00 & 22.91 & 13.00 & 22.98 \\
\hline $\mathrm{Gd}_{2} \mathrm{O}_{3}$ & 13.50 & 4.57 & 22.50 & 7.64 \\
\hline $\mathrm{HfO}_{2}$ & 7.00 & 4.08 & 7.00 & 4.09 \\
\hline $\mathrm{La}_{2} \mathrm{O}_{3}$ & 19.00 & 7.15 & 10.00 & 3.78 \\
\hline $\mathrm{Nd}_{2} \mathrm{O}_{3}$ & 15.00 & 5.47 & 15.00 & 5.49 \\
\hline $\mathrm{SiO}_{2}$ & 20.00 & 40.83 & 20.00 & 40.98 \\
\hline $\mathrm{SrO}$ & 2.50 & 2.96 & 2.50 & 2.97 \\
\hline & & & & \\
\hline Total & 100 & 100 & 100 & 100 \\
\hline
\end{tabular}


Visual observations for the two "modified" glasses are summarized in Table 8. Both systems were visually homogeneous with no undissolved solids in the pour patty or residual crucible glass.

Table 8. Visual Observations of High $\mathrm{Ln}_{2} \mathrm{O}_{3} \# 2 \mathrm{Mod}$ and High $\mathrm{Ln}_{2} \mathrm{O}_{3} \# 4 \mathrm{Mod}$

\begin{tabular}{|c|l|}
\hline GLASS ID & VISUAL OBSERVATIONS \\
\hline High $\mathrm{Ln}_{2} \mathrm{O}_{3} \# 2 \mathrm{Mod}$ & $\begin{array}{l}\text { Pour patty and residual crucible glass appeared "single } \\
\text { phase" - no undissolved solids. Nice "purple" clear glass. }\end{array}$ \\
\hline High $\mathrm{Ln}_{2} \mathrm{O}_{3} \# 4 \mathrm{Mod}$ & $\begin{array}{l}\text { Pour patty and residual crucible glass appeared "single } \\
\text { phase" - no undissolved solids. Nice "purple" clear glass. }\end{array}$ \\
\hline
\end{tabular}

\subsection{Surrogate Glass Characterization}

\subsubsection{Glass Composition Measurements}

In this section, the measured versus targeted compositions of select alternative surrogate Pu glasses are presented and compared. The targeted compositions for these glasses were provided in Tables 3 and 4 . The measured elemental concentrations were converted to oxide concentrations by multiplying the values for each element by the gravimetric factor for the corresponding oxide. A sum of oxides was computed for the measured analyses with an acceptance criterion of $95-105 \%$ sum of oxides used to assess the recovery.

Table 9 summarizes the targeted and measured composition as well as a relative $\%$ difference for each of the oxides. Based on a review of the data, the measured compositions agree quite well with the targeted compositions. More specifically, with the exception of the $\mathrm{HfO}_{2}$ content in the Frit B glass, all of the measurements for each oxide are within $\pm 10 \%$ of the targeted values. This indicates no significant batch errors occurred and/or minimal volatility during the melting process.

With respect to the $\mathrm{HfO}_{2}$ concentrations for the Frit B glass, the average measured value was $\sim 14.3 \mathrm{wt} \%$ in the glass while the targeted concentration was $\sim 15.9 \mathrm{wt} \%$ (a $\sim 12 \%$ difference). The lower "measured" value can be related to the presence of undissolved solids visually apparent in both the glass pour patty and the residual crucible glass (see Section 4.2.3 for SEM analysis supporting the presence of $\mathrm{HfO}_{2}$ ). A closer review of the $\mathrm{HfO}_{2}$ values for the alternative glasses shows that the measured values are within $\pm 5 \%$ of the targeted values. This agrees well with visual observations of homogeneity (i.e., undissolved solids were not visually noted) and suggests that the strategic compositional changes may maintain relatively high actinide solubility. 
Table 9. Compositional Analysis of Select Alternative Surrogate Glasses (mass \%)

\begin{tabular}{|c|c|c|c|c|c|c|c|c|c|c|}
\hline & $\mathrm{Al}_{2} \mathrm{O}_{3}$ & $\mathrm{~B}_{2} \mathrm{O}_{3}$ & $\mathrm{Fe}_{2} \mathrm{O}_{3}$ & $\mathrm{Gd}_{2} \mathrm{O}_{3}$ & $\mathrm{HfO}_{2}$ & $\mathrm{La}_{2} \mathrm{O}_{3}$ & $\mathrm{Nd}_{2} \mathrm{O}_{3}$ & $\mathrm{SiO}_{2}$ & $\mathrm{SrO}$ & Total \\
\hline Frit B (A) & 19.28 & 10.53 & - & 11.18 & 14.28 & 7.11 & 7.21 & 26.32 & 2.09 & 97.99 \\
\hline Frit B (B) & 19.28 & 10.27 & - & 11.05 & 14.28 & 7.04 & 7.10 & 25.89 & 2.09 & 97.01 \\
\hline Average & 19.28 & 10.40 & - & 11.11 & 14.28 & 7.08 & 7.15 & 26.11 & 2.09 & 97.50 \\
\hline Target & 19.17 & 10.44 & - & 11.52 & 15.94 & 7.29 & 7.38 & 26.01 & 2.25 & 100.00 \\
\hline \% Relative Difference & 0.56 & -0.38 & - & -3.65 & -11.64 & -2.99 & -3.15 & 0.38 & -7.73 & \\
\hline High $\mathrm{Ln}_{2} \mathrm{O}_{3} \# 2(\mathrm{~A})$ & 9.53 & 11.82 & - & 12.31 & 14.75 & 17.67 & 12.75 & 18.28 & 2.12 & 99.24 \\
\hline High $\mathrm{Ln}_{2} \mathrm{O}_{3} \# 2(\mathrm{~B})$ & 9.54 & 11.95 & - & 12.31 & 14.87 & 17.55 & 12.75 & 18.58 & 2.14 & 99.71 \\
\hline Average & 9.54 & 11.88 & - & 12.31 & 14.81 & 17.61 & 12.75 & 18.43 & 2.13 & 99.48 \\
\hline Target & 9.00 & 11.70 & - & 12.15 & 15.40 & 18.00 & 13.50 & 18.00 & 2.25 & 100.00 \\
\hline \% Relative Difference & 5.61 & 1.53 & - & 1.26 & -3.99 & -2.22 & -5.86 & 2.31 & -5.64 & \\
\hline High $\mathrm{Ln}_{2} \mathrm{O}_{3} \# 4(\mathrm{~A})$ & 9.60 & 12.20 & - & 21.28 & 14.99 & 8.93 & 12.40 & 18.17 & 2.18 & 99.82 \\
\hline High $\mathrm{Ln}_{2} \mathrm{O}_{3} \# 4(\mathrm{~B})$ & 9.58 & 12.04 & - & 21.16 & 15.10 & 8.93 & 12.17 & 18.13 & 2.24 & 99.43 \\
\hline Average & 9.59 & 12.12 & - & 21.22 & 15.05 & 8.93 & 12.29 & 18.15 & 2.21 & 99.63 \\
\hline Target & 9.00 & 11.70 & - & 21.15 & 15.40 & 9.00 & 13.50 & 18.00 & 2.25 & \\
\hline \% Relative Difference & 6.17 & 3.49 & - & 0.32 & -2.36 & -0.82 & -9.89 & 0.81 & -1.69 & \\
\hline $\mathrm{Fe}_{2} \mathrm{O}_{3}$ based \#2 (A) & 14.02 & 11.59 & 8.95 & 11.85 & 14.75 & 9.11 & 7.29 & 22.26 & - & 100.28 \\
\hline $\mathrm{Fe}_{2} \mathrm{O}_{3}$ based \#2 (B) & 13.99 & 11.50 & 8.92 & 11.85 & 14.63 & 9.08 & 7.29 & 22.26 & - & 99.97 \\
\hline Average & 14.00 & 11.54 & 8.94 & 11.85 & 14.69 & 9.10 & 7.29 & 22.26 & - & 100.13 \\
\hline Target & 13.50 & 11.70 & 9.00 & 11.52 & 15.40 & 9.00 & 7.38 & 22.50 & - & 100.00 \\
\hline$\%$ Relative Difference & 3.61 & -1.35 & -0.70 & 2.74 & -4.83 & 1.06 & -1.25 & -1.10 & - & \\
\hline $\operatorname{High} \mathrm{Ln}_{2} \mathrm{O}_{3} \# 2 \operatorname{Mod}(\mathrm{A})$ & 9.54 & 11.85 & - & 12.08 & 15.93 & 17.08 & 13.10 & 17.95 & 2.22 & 99.87 \\
\hline $\operatorname{High} \mathrm{Ln}_{2} \mathrm{O}_{3} \# 2 \operatorname{Mod}(\mathrm{B})$ & 9.54 & 11.95 & - & 12.31 & 16.17 & 17.20 & 13.46 & 18.08 & 2.23 & 101.04 \\
\hline Average & 9.54 & 11.90 & - & 12.19 & 16.05 & 17.14 & 13.28 & 18.02 & 2.22 & 100.46 \\
\hline Target & 9.00 & 11.70 & - & 12.15 & 16.30 & 17.10 & 13.50 & 18.00 & 2.25 & 100.00 \\
\hline \% Relative Difference & 5.70 & 1.66 & - & 0.33 & -1.57 & 0.24 & -1.66 & 0.10 & -1.16 & \\
\hline $\operatorname{High} \mathrm{Ln}_{2} \mathrm{O}_{3} \# 4 \operatorname{Mod}(\mathrm{A})$ & 9.53 & 11.85 & - & 20.24 & 15.93 & 8.99 & 13.34 & 18.19 & 2.17 & 100.26 \\
\hline $\operatorname{High~} \mathrm{Ln}_{2} \mathrm{O}_{3} \# 4 \mathrm{Mod}(\mathrm{B})$ & 9.51 & 11.88 & - & 20.24 & 16.05 & 9.03 & 13.22 & 17.98 & 2.21 & 100.14 \\
\hline Average & 9.52 & 11.87 & - & 20.24 & 15.99 & 9.01 & 13.28 & 18.08 & 2.19 & 100.20 \\
\hline Target & 9.00 & 11.70 & - & 20.25 & 16.30 & 9.00 & 13.50 & 18.00 & 2.25 & 100.00 \\
\hline \% Relative Difference & 5.42 & 1.40 & - & -0.05 & -1.95 & 0.10 & -1.66 & 0.46 & -2.79 & \\
\hline
\end{tabular}




\subsubsection{Glass Density}

Table 10 summarizes the density measurements (in $\mathrm{g} / \mathrm{cm}^{3}$ ) based on the Archimedes's Method (buoyancy) for select alternative Pu surrogate glasses. Also shown in Table 10 is the density range of a "typical" high level waste (HLW) glass for comparison. As anticipated, the high lanthanide based glasses have higher densities which resulted in the mass adjustment used during the PCT (durability) assessment.

Table 10. Density Measurements for the Alternative Pu Glasses

\begin{tabular}{|c|c|}
\hline Glass & Density (g/cm \\
\hline Frit B & 3.58 \\
\hline High $\mathrm{Ln}_{2} \mathrm{O}_{3} \# 2$ & 4.28 \\
\hline $\mathrm{High} \mathrm{Ln}_{2} \mathrm{O}_{3} \# 4$ & 4.31 \\
\hline $\mathrm{Fe}_{2} \mathrm{O}_{3} \mathrm{Based} \# 2_{2}$ & 3.81 \\
\hline $\mathrm{High} \mathrm{Ln}_{2} \mathrm{O}_{3} \# 2 \mathrm{Mod}$ & 4.31 \\
\hline High $\mathrm{Ln}_{2} \mathrm{O}_{3} \# 4$ Mod & 4.35 \\
\hline "Typical” HLW Glass & $2.5-2.7$ \\
\hline
\end{tabular}

\subsubsection{SEM and XRD Analyses}

A sample of the surrogate Frit $\mathrm{B}$ glass $\left(\mathrm{HfO}_{2}\right.$ surrogate for $\left.\mathrm{PuO}_{2}\right)$ was submitted for SEM analysis to further investigate the visual observations regarding undissolved or crystalline material in the glass. The analysis showed copious quantities of $\mathrm{HfO}_{2}$ crystals in the glass (Figure 8). The presence of the undissolved $\mathrm{HfO}_{2}$ provided an early indication of the potential solubility limitations of Frit $\mathrm{B}$ with respect to +4 valence elements (further insight was obtained shortly later in Cylindrical Induction Melter (CIM) testing with the Frit B composition - see Section 4.6). 

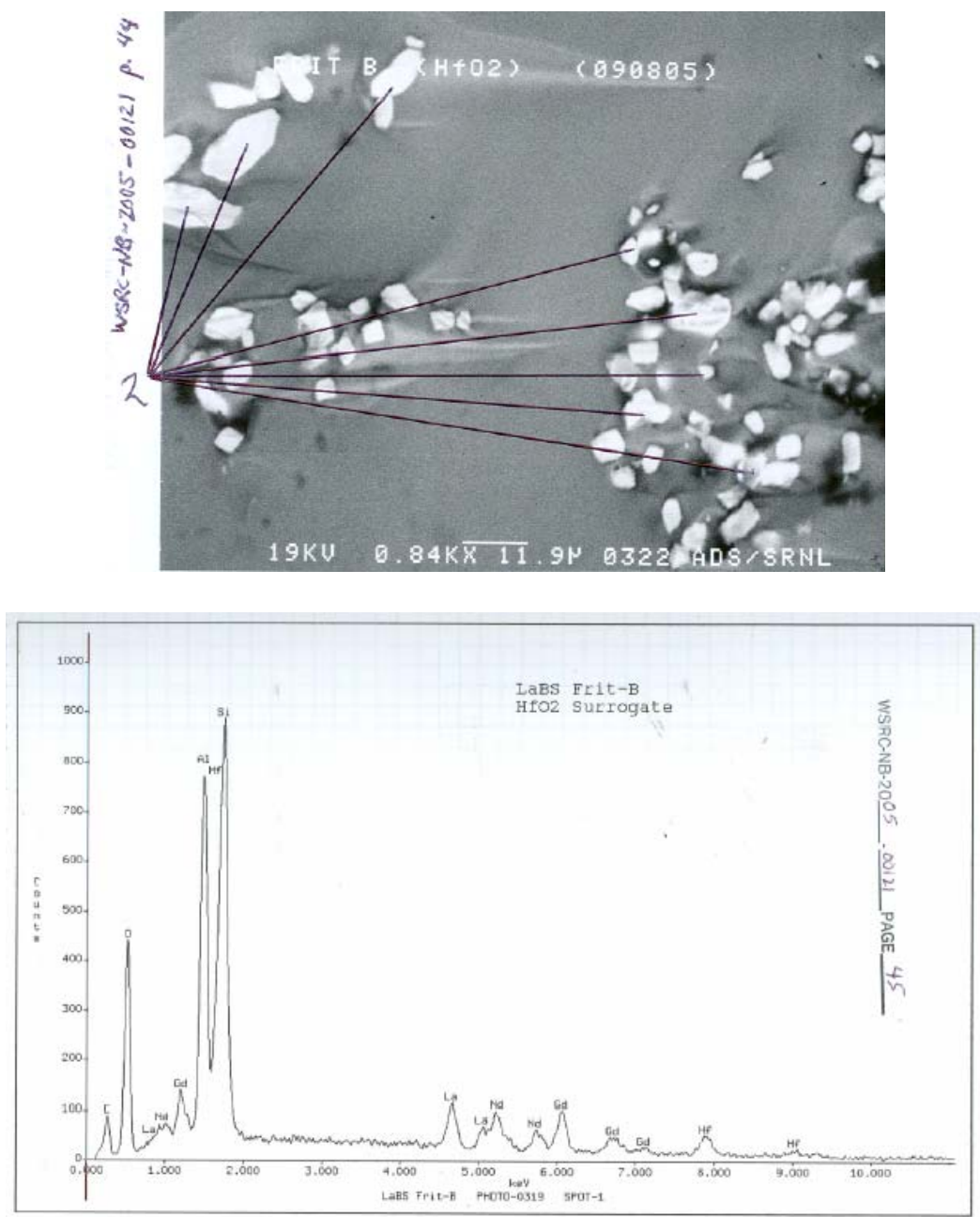

LaBS Frit-B PHOTO-0319 SPOT-1

Figure 8. SEM micrograph and corresponding EDS spectrum for surrogate Frit B glass.

A sample of surrogate High $\mathrm{Ln}_{2} \mathrm{O}_{3} \# 2$ Mod glass was also submitted for SEM analysis. The results indicated that the glass was essentially homogeneous with only a few areas where "clusters" of undissolved $\mathrm{HfO}_{2}$ were observed (Figure 9). A sample of High $\mathrm{Ln}_{2} \mathrm{O}_{3} \# 2$ Mod glass was also submitted for XRD analysis. Samples were run under conditions allowing a detection limit of approximately $0.5 \mathrm{vol} \%$. That is, if crystals (or undissolved solids) were present at $0.5 \mathrm{vol} \%$ (or greater), the diffractometer would not only be capable of detecting the crystals but would also allow a qualitative measure (i.e., determine the type of crystal[s] present). Otherwise, a characteristically high background devoid of crystalline spectral lines indicated that the glass product was amorphous (suggesting either a completely amorphous product or that the degree of crystallization was below the detection limit). Based on these conditions, the XRD scan of the High $\mathrm{Ln}_{2} \mathrm{O}_{3} \# 2$ Mod glass indicated that the glass was amorphous (Figure 10). 

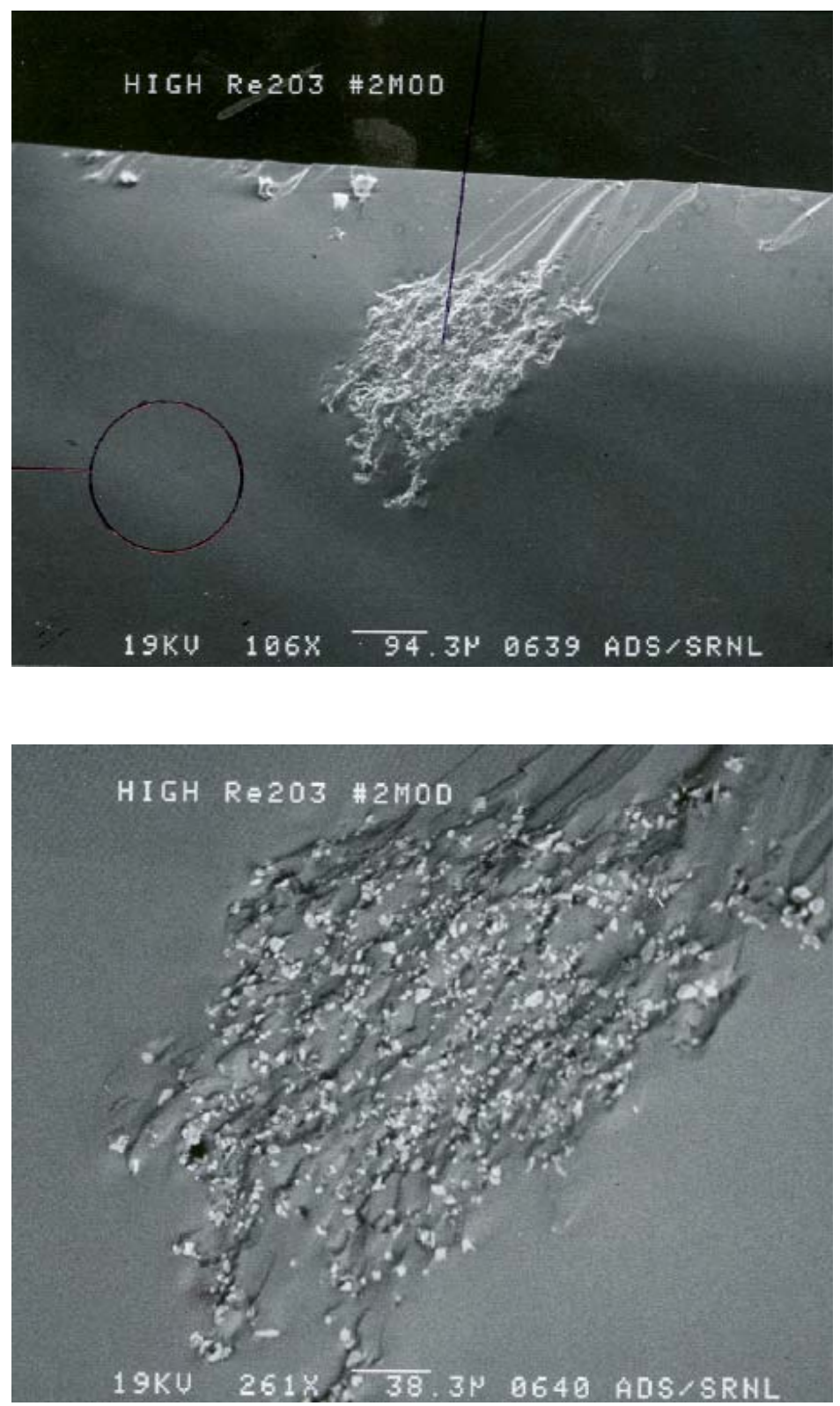

Figure 9. SEM micrograph and corresponding EDS spectrum for surrogate High $\mathrm{Ln}_{2} \mathrm{O}_{3} \# 2 \mathrm{Mod}$ glass. 


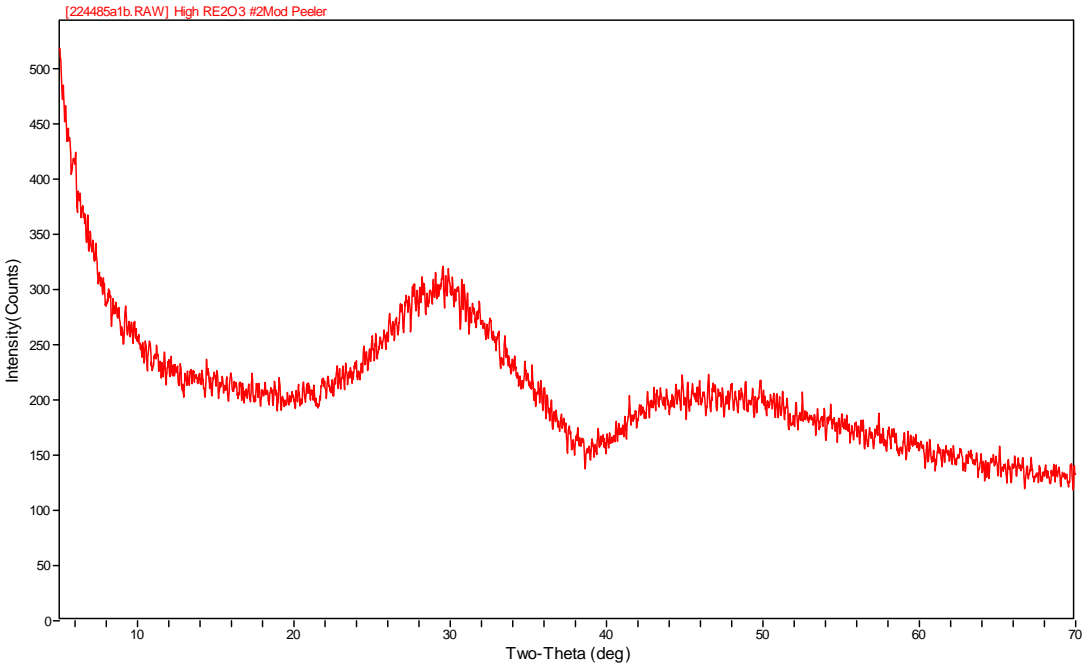

Figure 10. XRD scan for surrogate $\mathrm{High} \mathrm{Ln}_{2} \mathrm{O}_{3} \# 2$ Mod glass.

\subsection{Surrogate Glass PCT Results}

Table 11 summarizes the normalized releases for B and Si (NL [B] and NL [ Si], respectively) for select simulated alternative. It should be noted that $\mathrm{Li}$ and $\mathrm{Na}$ are not reported in Table 11 given the alternative $\mathrm{Pu}$ surrogate glasses do not contain these elements. In addition to the normalized releases, the average $\mathrm{pH}$ (of the triplicate PCTs) values are reported. The normalized releases and $\mathrm{pH}$ values for the Environmental Assessment (EA) glass are those reported by Jantzen et al. ${ }^{11}$.

As seen in Table 11, the durabilities for the alternative Pu surrogate glasses are much better than those of EA (this is indicated for a glass by its normalized leachate being smaller than that of EA). The NL [B]s for all of the surrogate glasses are $\sim 0.02 \mathrm{~g} / \mathrm{L}$ with very little if any differentiation (with respect to PCT releases). In terms of "acceptability", all simulated glasses are very acceptable glasses with respect to durability as defined by PCT. The measured normalized releases are consistent with previous assessments for the Frit A and Frit B based glasses. ${ }^{9,10}$ These results coupled with visual observations and SEM/XRD results, suggest that the compositional changes recommended may provide higher actinide solubility limits without compromising durability as measured by the PCT.

Table 11. Normalized Releases for Select Alternative Pu Glasses (g/L)

\begin{tabular}{|c|c|c|c|}
\hline Glass & $\begin{array}{c}\text { NL [B] } \\
(\mathbf{g} / \mathbf{L})\end{array}$ & $\begin{array}{c}\text { NL [Si] } \\
(\mathbf{g} / \mathbf{L})\end{array}$ & $\mathbf{p H}$ \\
\hline EA & 16.695 & 3.922 & 11.85 \\
\hline Frit B & 0.025 & 0.013 & 7.50 \\
\hline $\mathrm{Fe}_{2} \mathrm{O}_{3}$ Based \#2 & 0.024 & 0.026 & 6.94 \\
\hline $\mathrm{High} \mathrm{Ln} \mathrm{O}_{3} \# 2 \mathrm{Mod}$ & 0.021 & 0.014 & 7.59 \\
\hline $\mathrm{High} \mathrm{Ln} \mathrm{L}_{3} \# 4 \mathrm{Mod}$ & 0.020 & 0.011 & 7.54 \\
\hline
\end{tabular}




\subsection{Plutonium Glass Fabrication}

Based on the surrogate test results, the High $\mathrm{Ln}_{2} \mathrm{O}_{3} \# 2$ Mod glass was selected for follow-on plutonium glass fabrication. The surrogate work showed that this glass produced a homogeneous glass at high $\mathrm{HfO}_{2}$ loadings with durability (as measured by the PCT) equivalent to or better than the reference Frit B composition. This composition was also in the "recommended glass forming region" from the literature review and analyses conducted in this study. This composition was selected over its "formulation cousin" (High $\mathrm{Ln}_{2} \mathrm{O}_{3} \# 4$ Mod) because the relative lanthanide constituent composition was more balanced. The High $\mathrm{Ln}_{2} \mathrm{O}_{3} \# 2$ Mod composition was at this point dubbed "Frit X" to coincide with previous LaBS frit designations.

The Frit X composition was prepared and analyzed prior to plutonium glass fabrication. Duplicate measurements were made using ICP-AES on the digested glass. All frit elements were found to be within $\pm 10 \%$ of the targeted values. The measured boron value was approximately $9 \%$ lower than targeted indicating potential boron volatility. The sum of oxides for the measurements was approximately $98 \mathrm{wt}$ $\%$ indicating good elemental recovery for the analyses. The measured values (average of the duplicate measurements) vs. targeted are shown in Table 12.

Table 12. Measured vs. Targeted Composition for Frit X used in Pu Glass Fabrication

\begin{tabular}{|c|c|c|}
\hline Oxide & Targeted (wt \%) & Measured (wt \%) \\
\hline $\mathbf{A l}_{2} \mathbf{O}_{3}$ & 10.0 & 10.4 \\
\hline $\mathbf{B}_{2} \mathbf{O}_{3}$ & 13.0 & 11.8 \\
\hline $\mathbf{G d}_{2} \mathbf{O}_{3}$ & 13.5 & 13.6 \\
\hline $\mathbf{H f O}_{2}$ & 7.0 & 6.6 \\
\hline $\mathbf{L a}_{2} \mathbf{O}_{3}$ & 19.0 & 18.9 \\
\hline $\mathbf{N d}_{2} \mathbf{O}_{3}$ & 15.0 & 13.9 \\
\hline $\mathbf{S i O}_{2}$ & 20.0 & 20.3 \\
\hline $\mathbf{S r O}$ & 2.5 & 2.6 \\
\hline
\end{tabular}

The plutonium oxide material was obtained from Actinide Technology Section personnel. Analyses were conducted to determine the actinide isotopic distribution as well as screen for the presence of any gross impurity levels in the material. The results of these analyses are detailed elsewhere.. ${ }^{23}$

The $\mathrm{PuO}_{2}$ glass batches were prepared and melted as described in Section 2.3.2. The resulting glass appeared homogenous when visually examined in the crucible. Quenching of the glass was found to be ineffective in facilitating glass removal from the crucible (i.e., glass did not crack away from the crucible). Thus, the glass was not able to be removed from the crucible via routine means and "hammering" of the glass from the crucible was required. This resulted in pieces of glass (cullet) for follow-on analysis. This made it impractical to distinguish where the piece of glass originated with respect to the crucible melt. This precluded the ability to quantify any stratification of $\mathrm{PuO}_{2}$ that may have occurred in the glass melt. Previous analyses by Vienna, et al. identified stratification of $\mathrm{PuO}_{2}$ in plutonium loaded LaBS glasses fabricated in relatively small static crucible melts. ${ }^{6}$. Follow-on testing should be performed to assess stratification of $\mathrm{PuO}_{2}$ in this glass. 


\subsection{Plutonium Glass Characterization}

\subsubsection{SEM and XRD Analyses}

A sample of the Pu-containing Frit X glass was submitted for XRD and SEM analyses. The XRD analysis indicated that there was some crystalline $\mathrm{PuO}_{2}$ in the glass (Figure 11). Consistent with the XRD scan, the SEM analyses showed the presence of some undissolved $\mathrm{PuO}_{2}$ particles with a disk-like morphology (Figure 12). This observation was consistent with previous microscopy analyses on $\mathrm{Pu}$ loaded Frit B glass. ${ }^{23}$ It should be noted that the relative amount of undissolved $\mathrm{PuO}_{2}$ looked to be less in the Frit X composition when compared to the previously analyzed Frit B composition. This was consistent with the expected enhanced $\mathrm{PuO}_{2}$ solubility afforded by the Frit $\mathrm{X}$ composition. As mentioned previously, it is expected that stirring and/or co-grinding of the frit and $\mathrm{PuO}_{2}$ would likely enhance dissolution. A second crystalline phase was observed with a very unique "star-like" morphology (Figure 13). This phase was in the glass with slightly less abundance than the undissolved $\mathrm{PuO}_{2}$ phase. The phase was present either as well-developed "stars" (Figure 13) or as smaller "triangular" crystals (likely the early formation of the star-like crystals). The EDS spectra (Figure 13) of the star-like crystals indicated the presence of both $\mathrm{Pu}$ and $\mathrm{Hf}$ implying that these crystals were a solid solution of $\mathrm{PuO}_{2}$ and $\mathrm{HfO}_{2}$. These crystals likely formed during cooling of the glass and nucleated on the glass surface and/or at the crucible wall. The relative durability of this solid solution may be of special interest since the phase contains both $\mathrm{PuO}_{2}$ and a neutron absorber $\left(\mathrm{HfO}_{2}\right)$. The potential to intentionally precipitate this phase in the glass may offer the potential for a waste form with enhanced durability. Initial testing to achieve this result was conducted in this study and is detailed below (see Section 4.6).

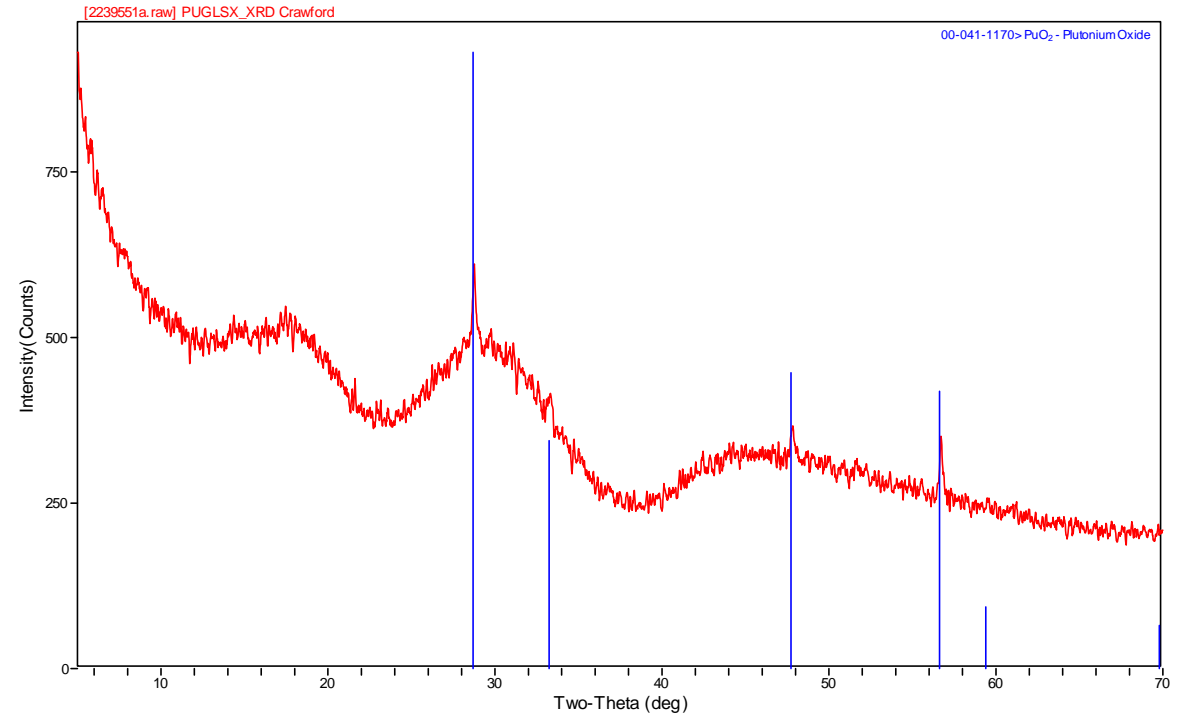

Figure 11. XRD scan of plutonium Frit $\mathrm{X}$ glass showing undissolved $\mathrm{PuO}_{2}$. 

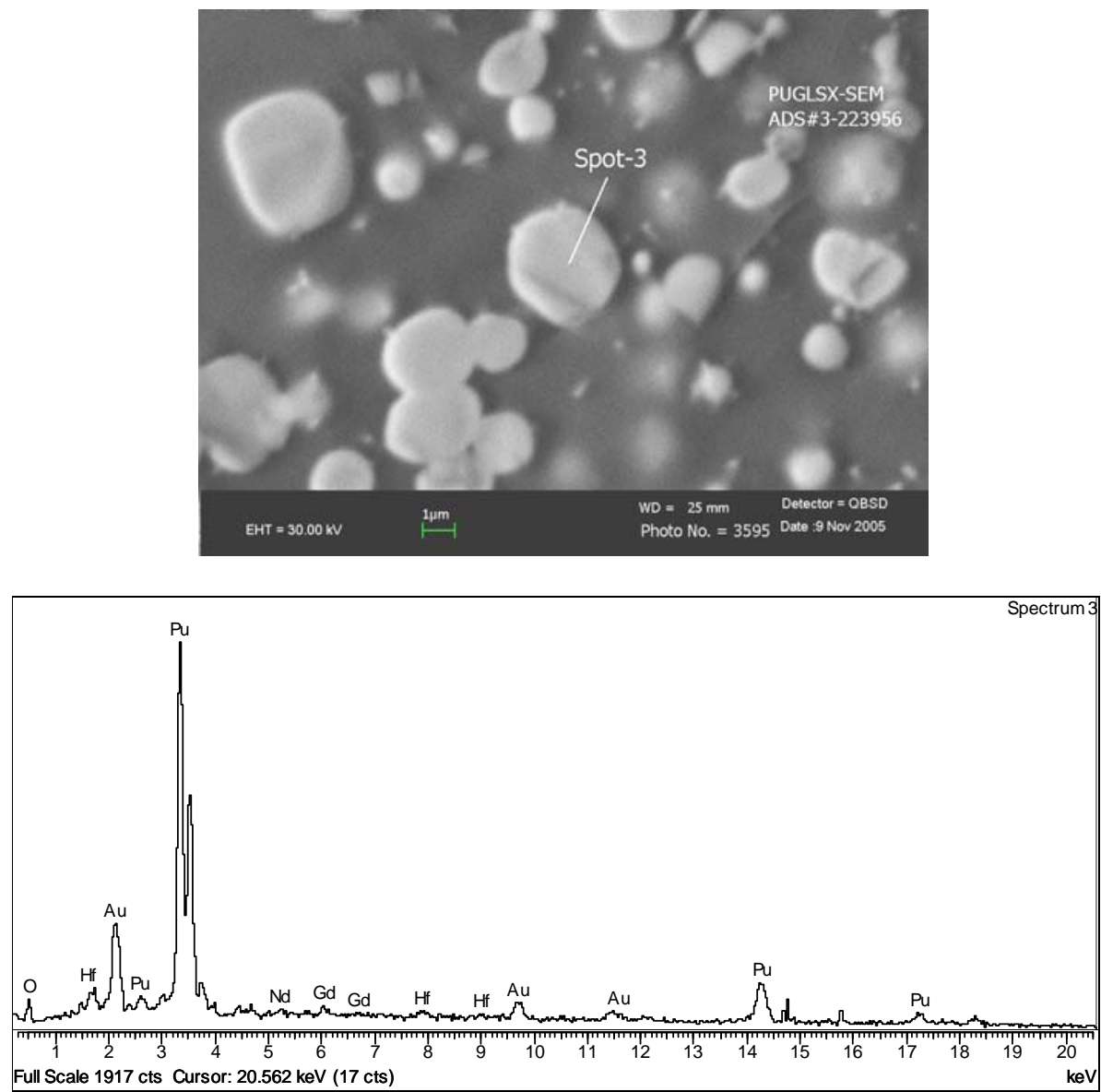

Figure 12. SEM micrograph and corresponding EDS spectra showing undissolved $\mathrm{PuO}_{2}$ in the Frit $\mathrm{X}$ glass. 

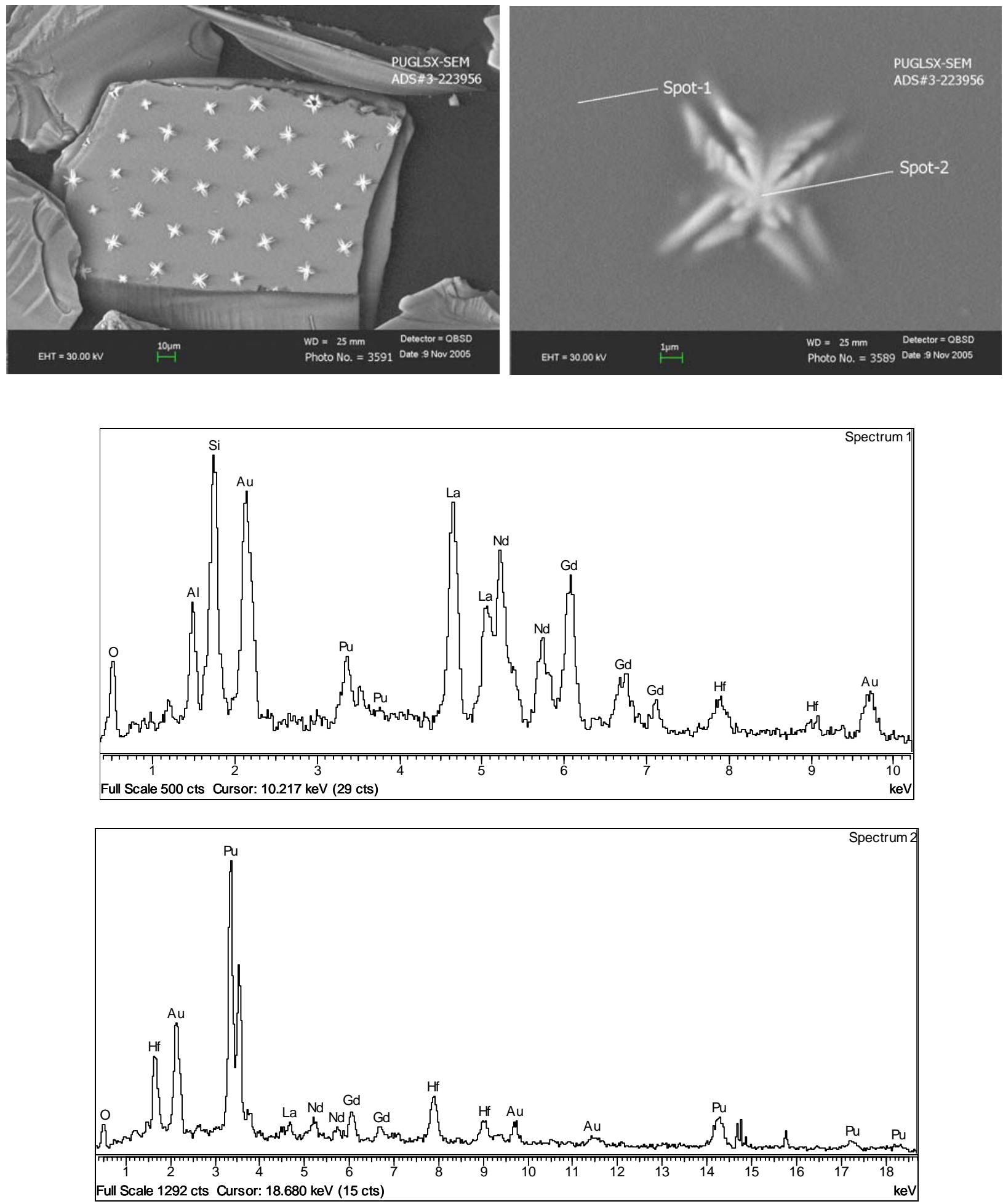

Figure 13. SEM micrograph and corresponding EDS spectra showing $\mathrm{PuO}_{2}-\mathrm{HfO}_{2}$ phase in the Frit $\mathrm{X}$ glass. 


\subsection{Glass Heat Treatment}

Concurrent with the formulation development efforts, melter testing with the Frit B composition using $\mathrm{HfO}_{2}$ as a surrogate for plutonium was also pointing to hafnium solubility and liquidus temperature issues. At this point, it was evident that at these high hafnium oxide concentrations, the solubility of hafnium oxide was exceeded in the Frit $\mathrm{B}$ glass. The use of zirconium oxide as a surrogate for $\mathrm{PuO}_{2}$ was evaluated and determined to be an adequate simulant for the melter testing. Crucible scale tests using $\mathrm{ZrO}_{2}$ added to the glass on an equivalent molar basis to $\mathrm{PuO}_{2}$ resulted in a homogenous glass and melter testing commenced using this composition. During melter testing, however, there were some issues with glass draining from the melter. During one test, the drain tube plugged and it was necessary to remove the plugged section of the drain tube to continue operations. Glass was removed from the drain tube and submitted for SEM analysis. It was obvious from visual examination that glass devitrification had occurred in the drain tube. It was likely that lower temperatures where experienced in the drain tube during processing leading to devitrification. To support the melter testing and further assess the devitrification behavior of the surrogate Frit $\mathrm{B}$ glass $\left(\mathrm{ZrO}_{2}\right.$ as a surrogate for $\left.\mathrm{PuO}_{2}\right)$, several isothermal heat treatments were conducted on the glass for subsequent analysis.

The surrogate Frit $\mathrm{X}$ composition $\left(\mathrm{HfO}_{2}\right.$ as a surrogate for $\left.\mathrm{PuO}_{2}\right)$ was also subjected to isothermal heat treatments. There were three reasons for this testing. The first was to assess the devitrification behavior to compare to the reference Frit B composition. The second was to assist in defining a temperature window for heat treating the plutonium glass to intentionally form the $\mathrm{PuO}_{2}-\mathrm{HfO}_{2}$ solid solution in the glass. The results of this testing would then be used as a guide for actual plutonium glass testing. A third reason was to provide additional insight into the possibility of lowering melt temperature.

\subsubsection{XRD and SEM Analyses}

\subsubsection{Surrogate Frit B Analyses}

As indicated above, the surrogate plutonium glass that had crystallized in the drain tube of the CIM was examined by SEM. The micrographs indicated that rod like precipitates of $\mathrm{HfO}_{2}-\mathrm{ZrO}_{2}$ (where $\mathrm{ZrO}_{2}$ was the surrogate for $\mathrm{PuO}_{2}$ ) had formed in the glass. The precipitates were often found at right angles to each other (Figure 14). These rod shaped precipitates, and the associated box-like precipitation pattern, may participate in microcracking as the glass along the precipitate grain boundary exhibits microcracking.

The rod shaped precipitate morphology appeared in internal surfaces of the broken glass while irregular plate-like morphology crystals appeared on the surface. The chemistry of the rod shaped precipitates and the plate-like crystals was similar.

Glasses that had poured from the CIM before it plugged were heat treated at $1350^{\circ} \mathrm{C}$ and $1400^{\circ} \mathrm{C}$ for 24 hours to determine if devitrification had occurred in the CIM drain tube. The same flake and rod shaped $\mathrm{ZrO}_{2}-\mathrm{HfO}_{2}$ precipitates were visible in both devitrified samples. The same box-like precipitation pattern was observed for the rod-shaped precipitates in both samples. In the $1400^{\circ} \mathrm{C}$ sample there is evidence that the rod shaped precipitates grow from individual spherical precipitates of $\mathrm{HfO}_{2}-\mathrm{ZrO}_{2}$ like the spherical disk-like phase observed in the Pu glasses (Figure 15). 


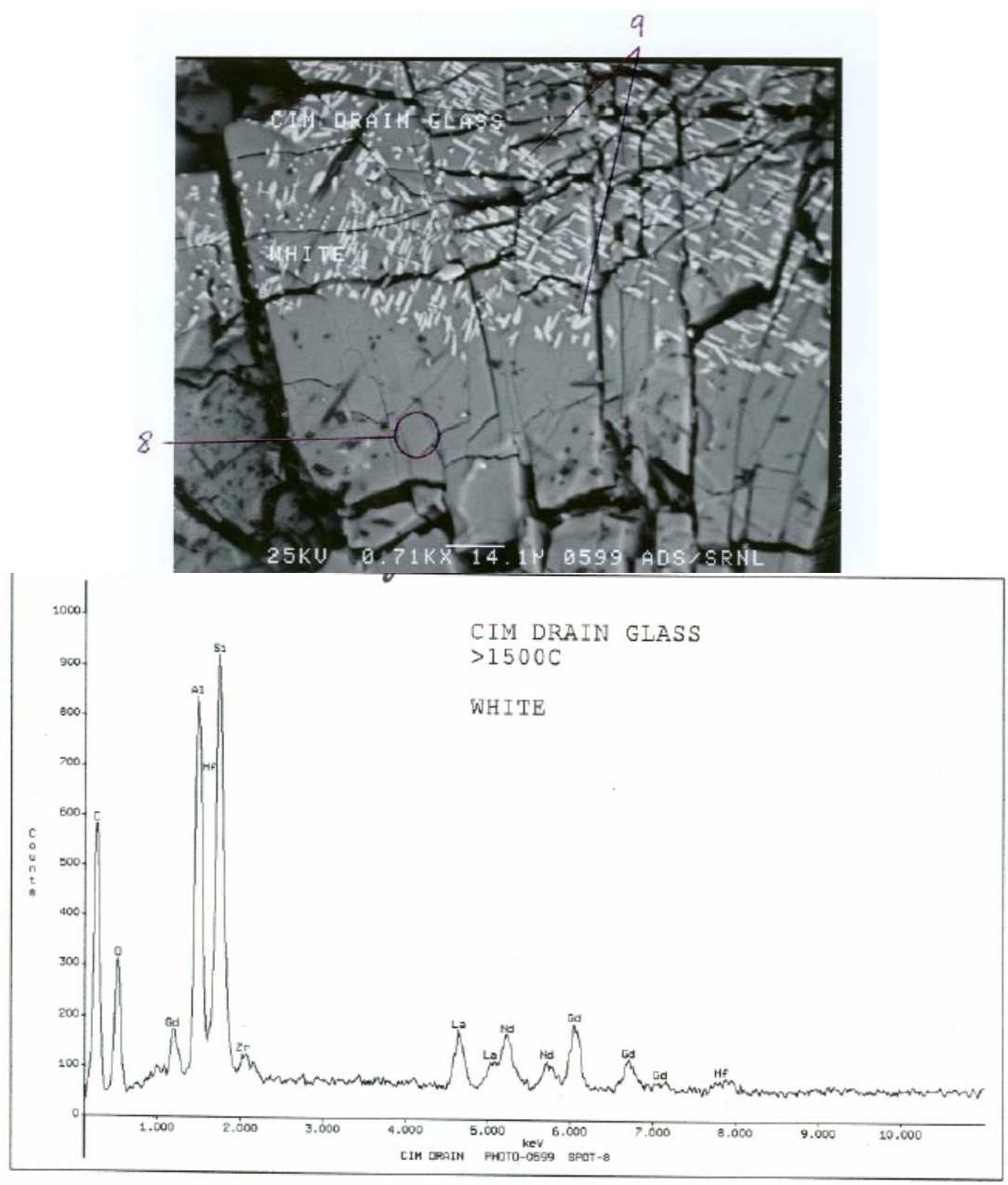

CIM DRAIN PHOTO-0599 SPOT-8

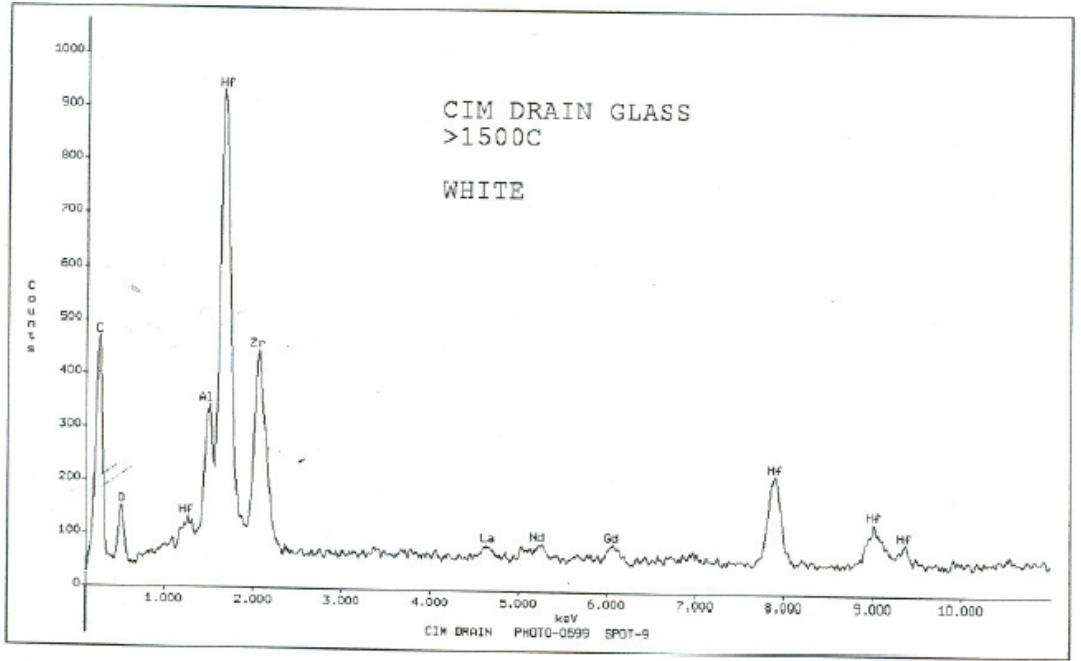

CIM DRAIN PHOTO-0599 SPOT-9

Figure 14. SEM micrograph and corresponding EDS spectra of surrogate Frit $B$ glass from the CIM drain tube showing $\mathrm{HfO}_{2}-\mathrm{ZrO}_{2}$ phase glass precipitated in the glass. 


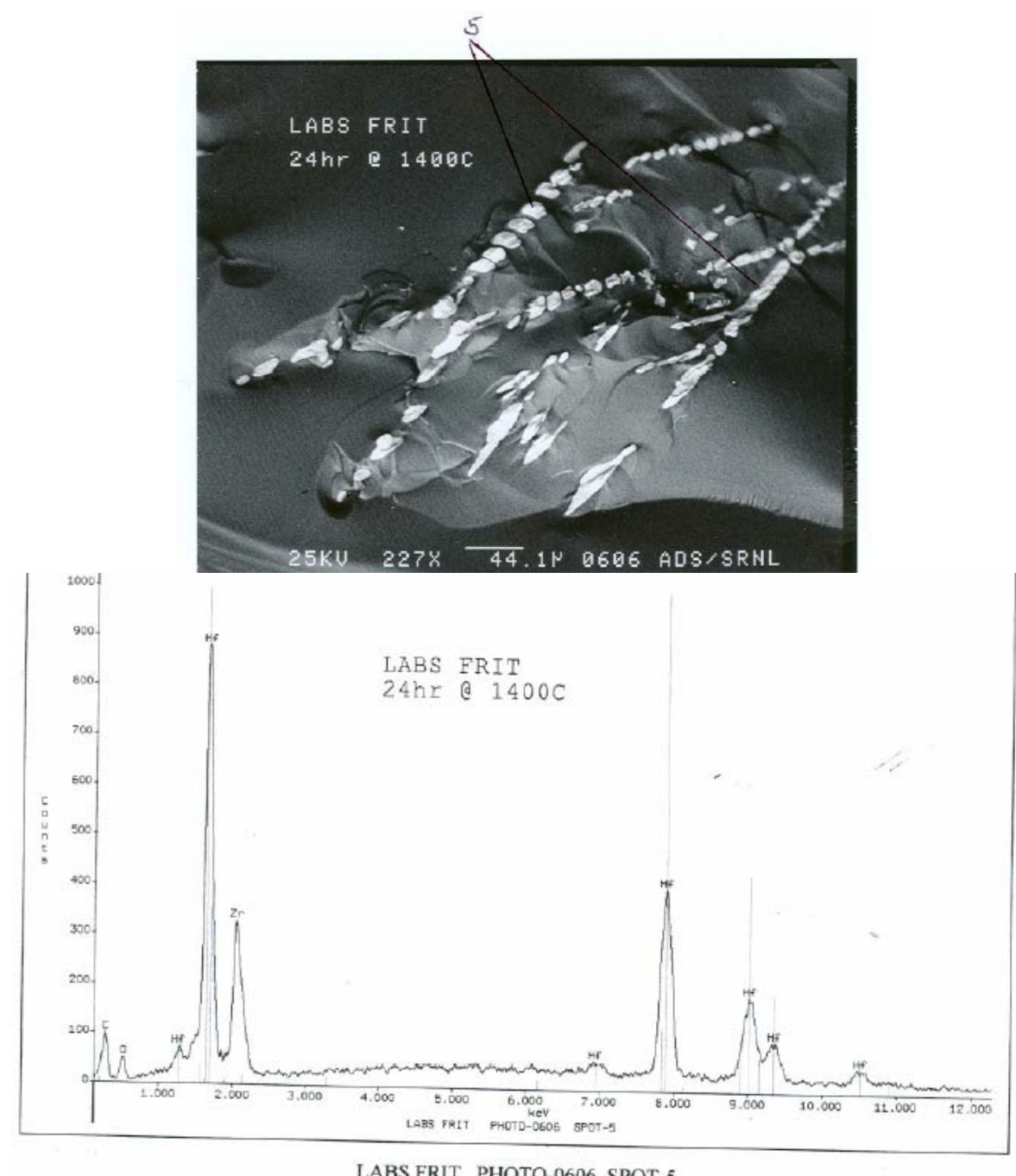

Figure 15. SEM micrograph and corresponding EDS spectra of surrogate Frit B glass from CIM testing heat treated at $1400^{\circ} \mathrm{C}$.

\subsubsection{Surrogate Frit X Analyses}

A series of isothermal heat treatments was conducted on the surrogate Frit X composition $\left(\mathrm{HfO}_{2}\right.$ as a surrogate for $\mathrm{PuO}_{2}$ ) to assess the devitrification behavior of the glass. Heat treatments were conducted for 24 hours at $1400^{\circ} \mathrm{C}, 1350^{\circ} \mathrm{C}, 1300^{\circ} \mathrm{C}, 1250^{\circ} \mathrm{C}, 1200^{\circ} \mathrm{C}, 1100^{\circ} \mathrm{C}, 1000^{\circ} \mathrm{C}$, and $900^{\circ} \mathrm{C}$. Samples were submitted for XRD analysis. The XRD scans are shown in Figure 16.

The XRD results for the glass sample heat treated at $1400^{\circ} \mathrm{C}$ indicated that the glass was amorphous (or free of crystals to the detection limit of $0.5 \mathrm{vol} \%$ ). Additionally, only a few reflections with very low intensity were found in the $1350^{\circ} \mathrm{C}$ heat treated sample. These low intensity peaks could not be indexed to a known crystalline phase. These results indicated that the liquidus temperature behavior of the Frit $\mathrm{X}$ glass was markedly improved over the reference Frit B glass. This should facilitate melting the Frit X glass at a lower temperature and an expected improvement in processing in the CIM (e.g., precluding drain tube pluggage). 
The XRD scans of the samples heat treated at $1200,1250,1300$ and $1350^{\circ} \mathrm{C}$ showed that the thermal treatments caused hafnium oxide to be precipitated in the glass. The relative amount of $\mathrm{HfO}_{2}$ increased as the heat treatment temperature was decreased. These results indicated that there was a relatively large window where a solid solution of $\mathrm{PuO}_{2}-\mathrm{HfO}_{2}$ could be potentially precipitated in the glass via postmelting thermal treatment. SEM analysis was conducted on a sample subjected to the $1200^{\circ} \mathrm{C}$ isothermal treatment (Figure 17). The micrographs clearly show the formation of a well-developed $\mathrm{HfO}_{2}$ phase in the glass with a plate-like morphology. A finer rod-like phase was also observed (Figure 18). There were some indications that the finer, rod-like crystals were actually less-developed $\mathrm{HfO}_{2}$ crystals. A similar rod-like phase was observed in the surrogate Frit B glass samples obtained from the CIM drain tube and samples heat treated at 1350 and $1400^{\circ} \mathrm{C}$.

The XRD results for the surrogate Frit $\mathrm{X}$ samples heat treated at 1000 and $1100^{\circ} \mathrm{C}$ indicated that in this temperature range various mixed-rare earth oxides formed in the glass in addition to $\mathrm{HfO}_{2}$. The sample heat treated at $900^{\circ} \mathrm{C}$ showed only very minor peaks that corresponded to mixed-rare earth oxide phases. 
WSRC-TR-2006-00031

Revision 0

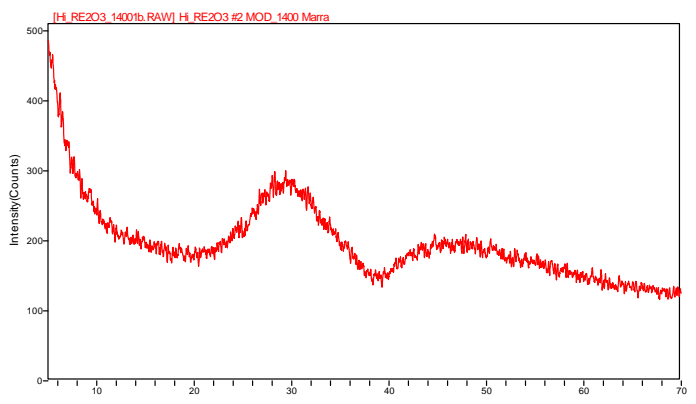

$1400^{\circ} \mathrm{C}$

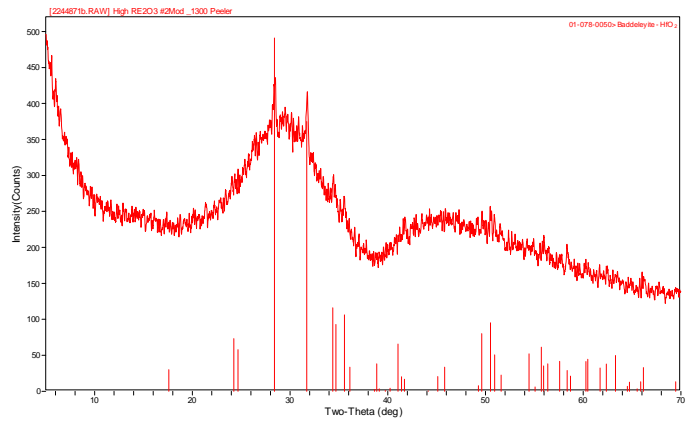

$1300^{\circ} \mathrm{C}$

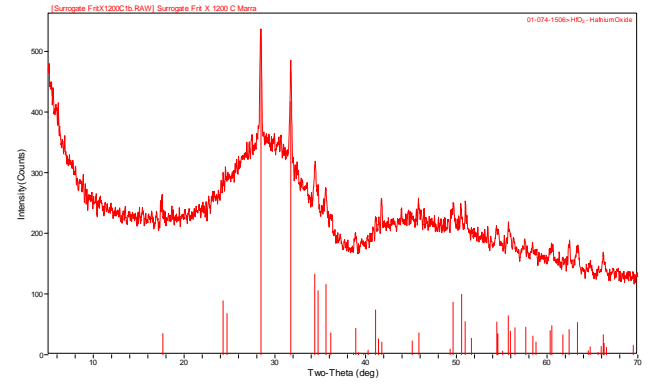

$1200^{\circ} \mathrm{C}$

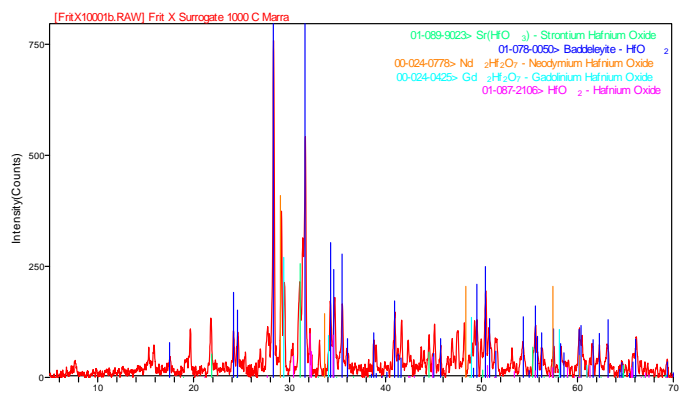

$1000^{\circ} \mathrm{C}$

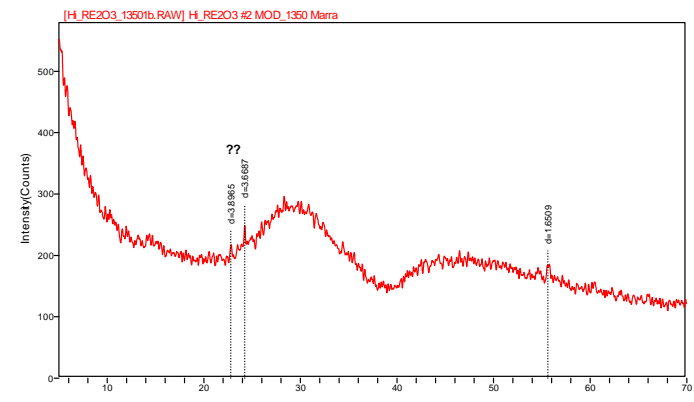

$1350^{\circ} \mathrm{C}$

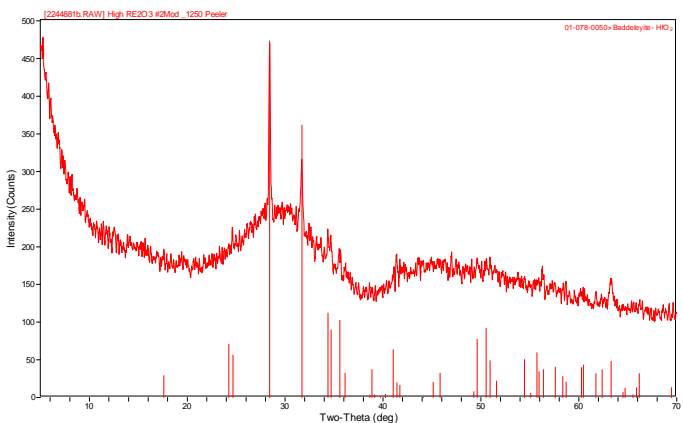

$1250^{\circ} \mathrm{C}$

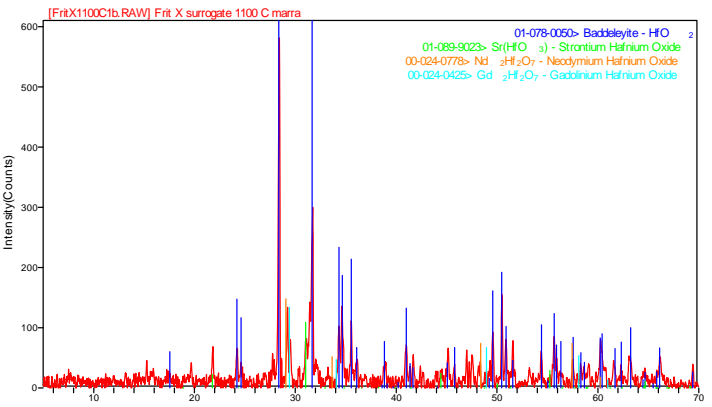

$1100^{\circ} \mathrm{C}$

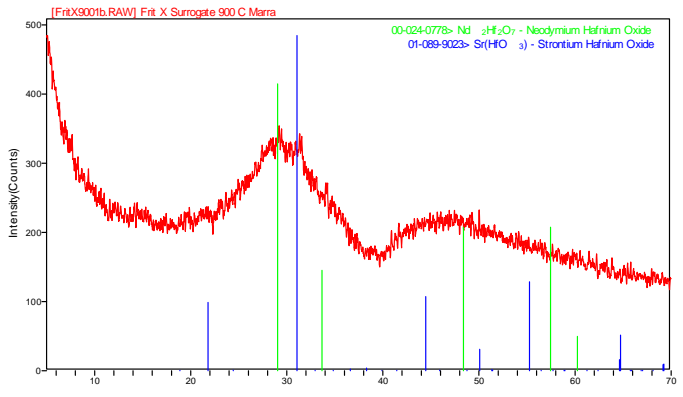

$900^{\circ} \mathrm{C}$

Figure 16. XRD Scans for heat treated surrogate Frit $X$ glass. 

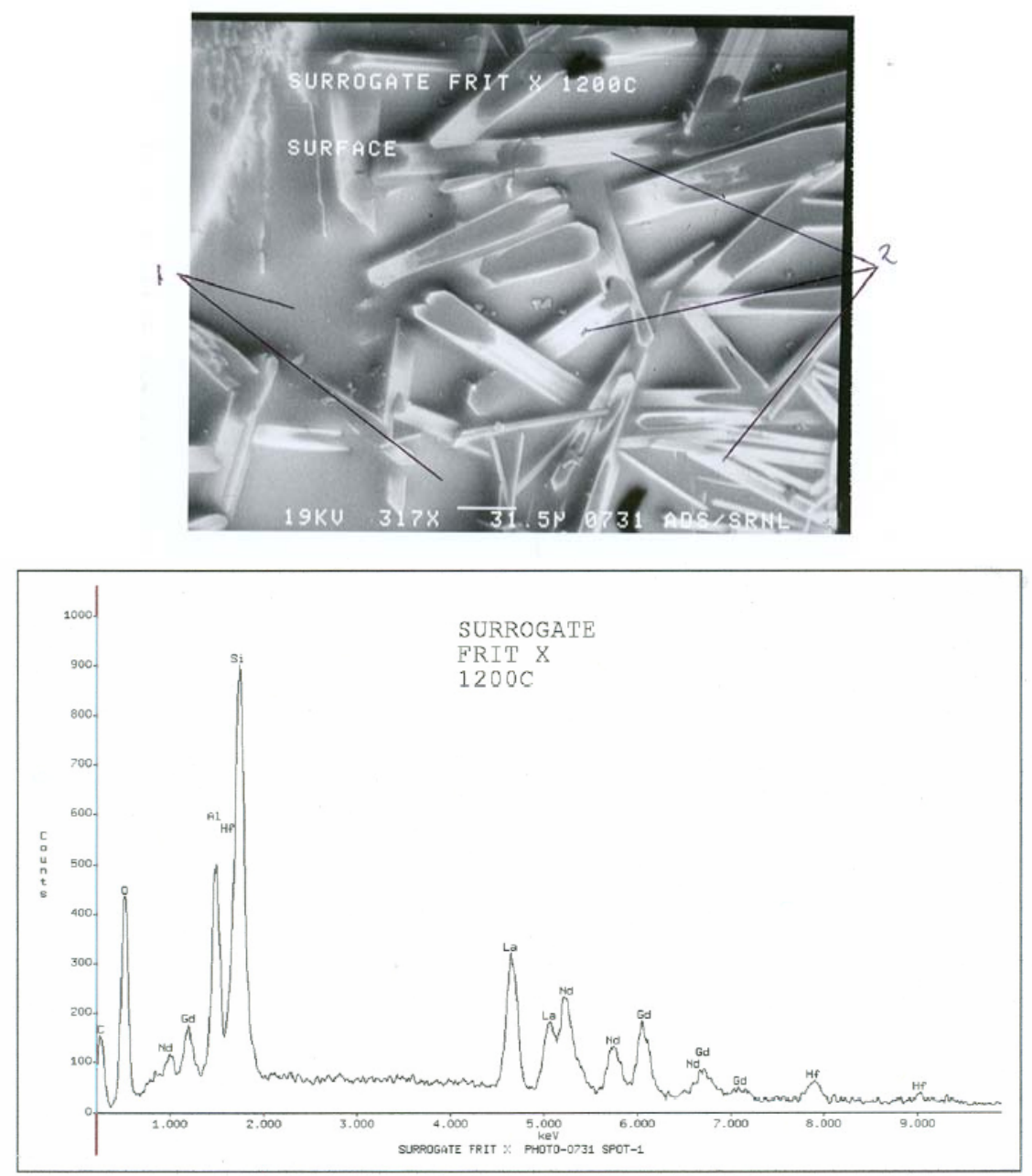

SURROGATE FRIT X PHOTO-0731 SPOT-1

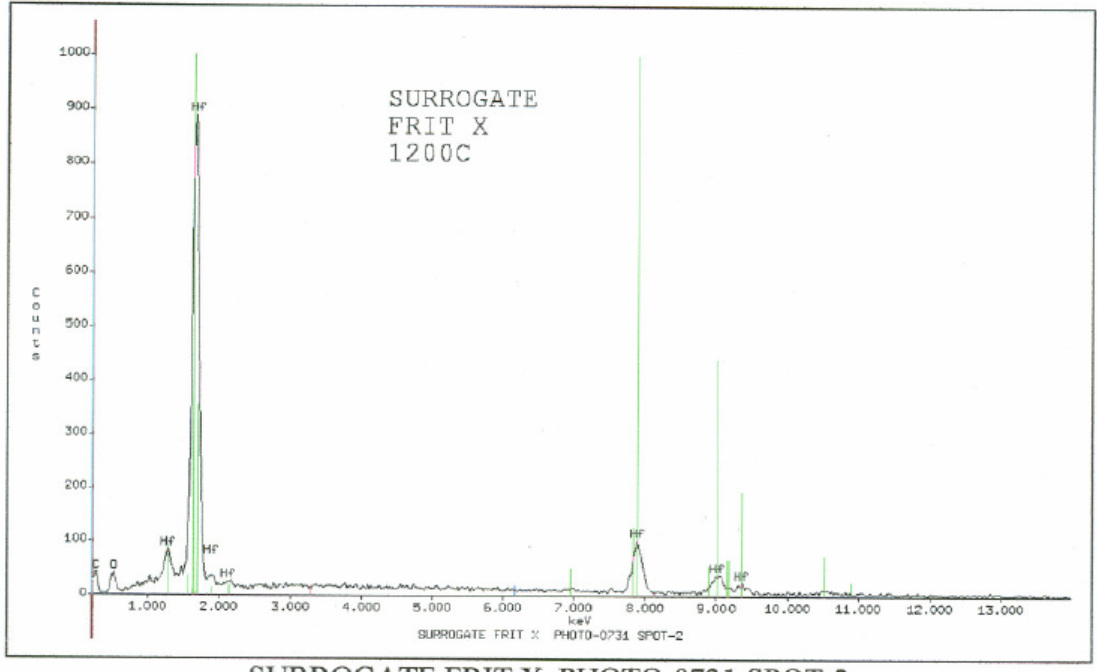

SURROGATE FRIT X PHOTO-0731 SPOT-2

Figure 17. SEM micrograph and corresponding EDS spectra showing $\mathrm{HfO}_{2}$ phase precipitated in the surrogate Frit $\mathrm{X}$ glass after heat treatment at $1200^{\circ} \mathrm{C}$. 

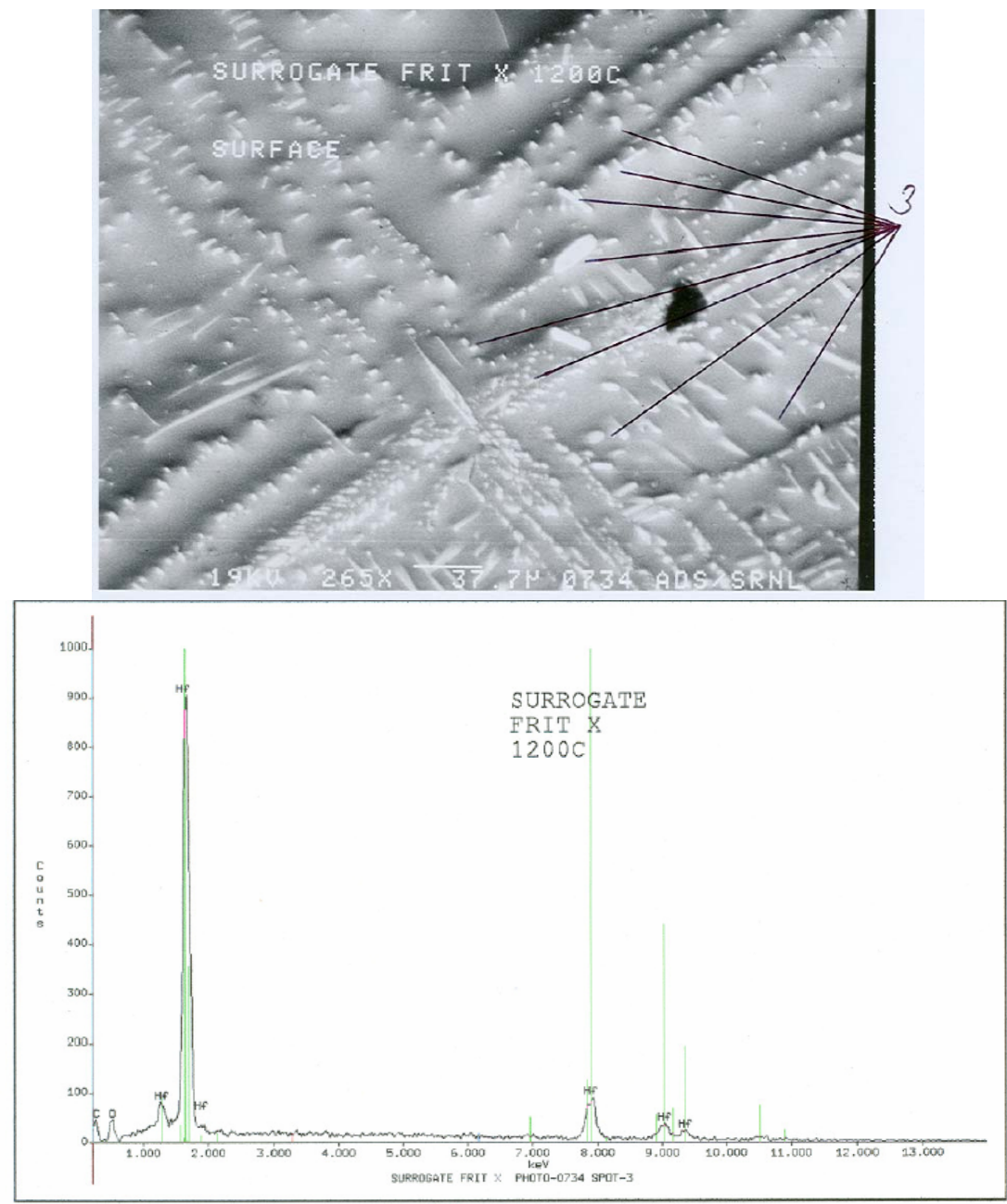

SURROGATE FRIT X PHOTO-0734 SPOT-3

Figure 18. SEM micrograph and corresponding EDS spectra showing fine $\mathrm{HfO}_{2}$ phase precipitated in the surrogate Frit $\mathrm{X}$ glass after heat treatment at $1200^{\circ} \mathrm{C}$.

\subsubsection{Plutonium Frit X Glass Analyses}

Based on the results of the surrogate heat treatment testing, the plutonium-containing Frit $\mathrm{X}$ glass was isothermally heat treated to evaluate the potential for intentionally precipitating the $\mathrm{PuO}_{2}-\mathrm{HfO}_{2}$ crystalline phase. Due to an operational issue with the primary radioactive high temperature furnace, a secondary furnace was utilized for heat treating the glass. This back-up furnace was limited to a maximum operating temperature of $1200^{\circ} \mathrm{C}$. This temperature was at the low end of the "window" determined in the surrogate testing for precipitating $\mathrm{HfO}_{2}$ in the glass but it was still deemed worthwhile to perform a heat treatment on the Pu Frit X glass at this temperature. A sample of the Pu-bearing Frit X glass was heat treated for about 10 hours at $1200^{\circ} \mathrm{C}$. Sub-samples of the heat treated glass were analyzed by SEM and XRD. 
The SEM results showed that significant crystallization occurred in the glass (Figure 19). The EDS spectra for the plate-like crystalline phase (spot 5) indicated that this phase was likely a mixed-rare earth oxide that was devoid of hafnium. A finer-sized crystalline phase (spot 7) was also observed and appeared to be enriched in plutonium and included all of matrix glass elements. In an effort to better quantify the composition of the enriched plutonium phase, the beam current was reduced on the microscope to minimize the penetration through the phase and into the matrix glass. This was somewhat successful and the resulting EDS spectra indicated that this phase was primarily plutonium oxide (Figure 20). There appeared to be continued beam penetration as pronounced silicon and aluminum peaks were again observed. The "shoulder" on the primary silicon peak implied that this phase also included Hf in the composition. The XRD pattern for the heat treated Pu-containing Frit X glass showed a predominance of mixed-rare earth oxide (Figure 21). It was evident from these analyses that heat treatment at $1200^{\circ} \mathrm{C}$ did not provide the desired result of forming an abundant $\mathrm{PuO}_{2}-\mathrm{HfO}_{2}$ phase in the glass. Follow-on work will be conducted at higher thermal treatment temperatures in an attempt to achieve this result. 

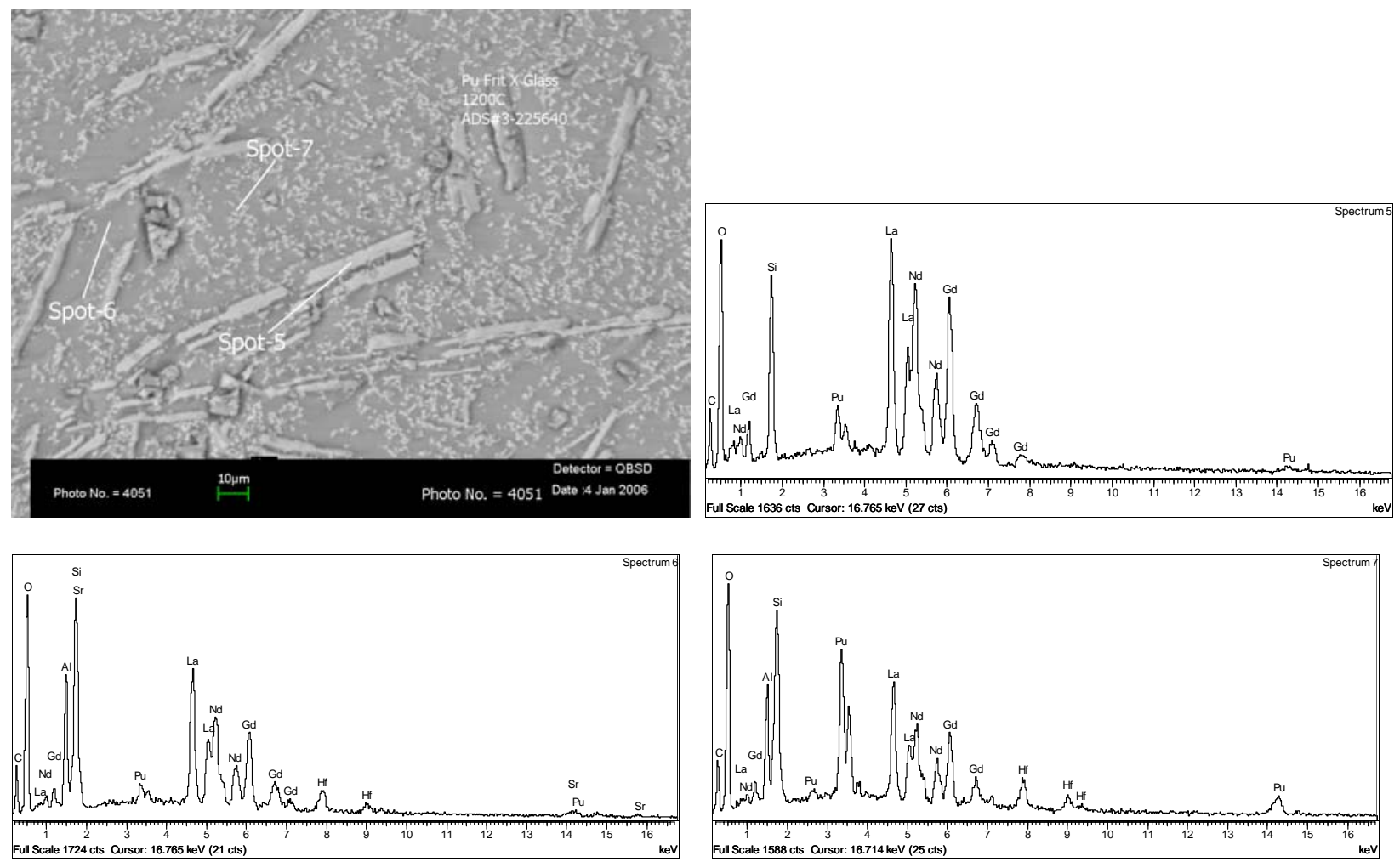

Figure 19. SEM micrograph and corresponding EDS spectra showing $\mathrm{HfO}_{2}$ phase precipitated in the plutonium-containing Frit $\mathrm{X}$ glass after heat treatment at $1200^{\circ} \mathrm{C}$

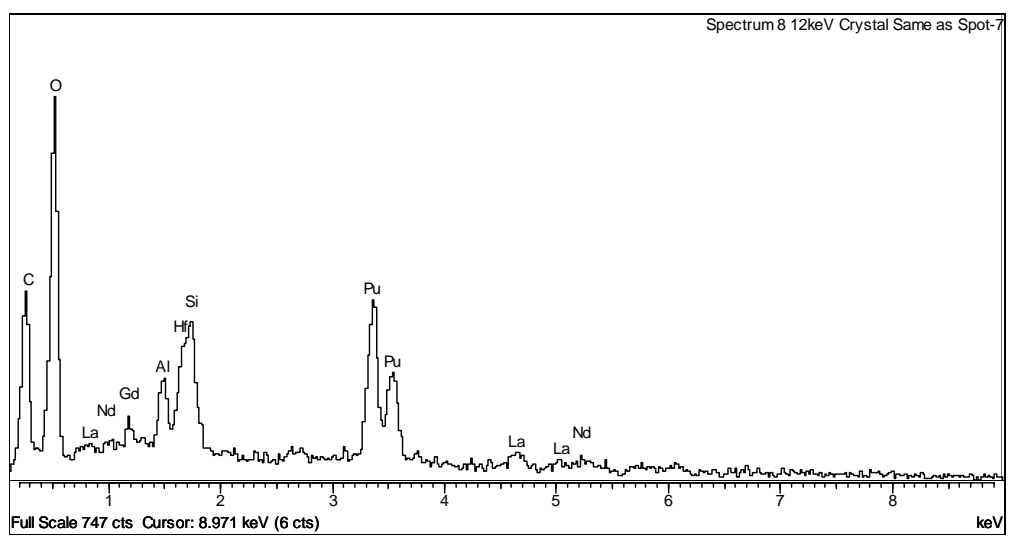

Figure 20. EDS spectra of spot 7 in Figure 4-11 with a beam current of $12 \mathrm{keV}$ 


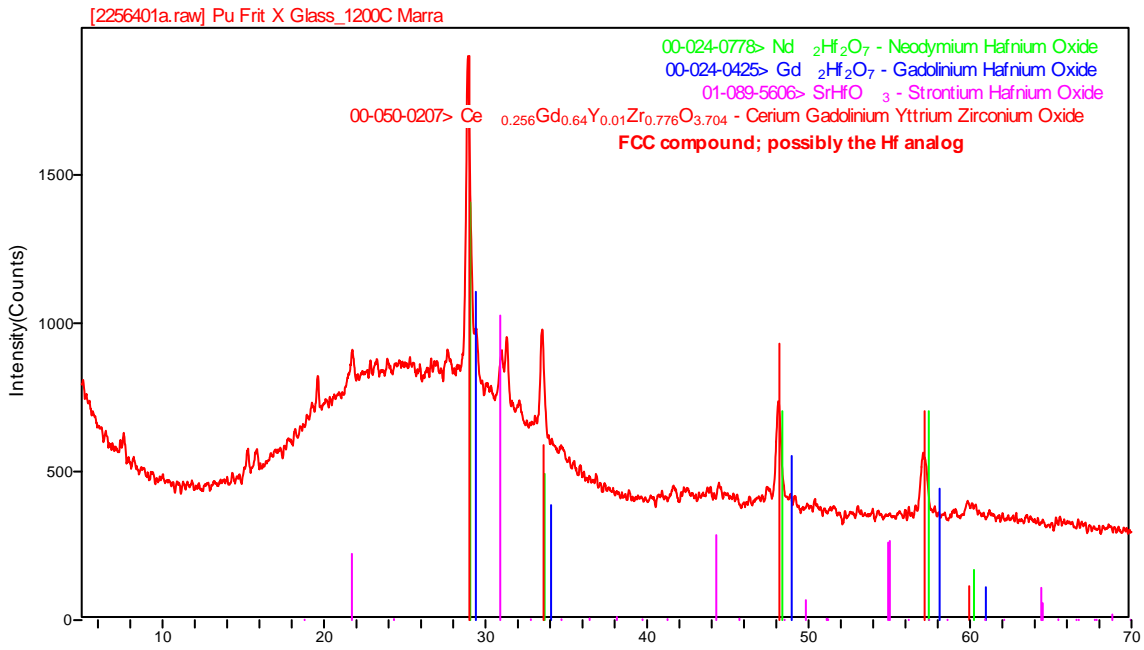

Note: The Cerium Gadolinium Yttrium Zirconium Oxide phase is not possible to form with the composition of glass. However, a similar phase with substituted lanthanides in this stoichiometry is possible.

Figure 21. XRD Scan for plutonium-containing Frit $X$ glass heat treated at $1200^{\circ} \mathrm{C}$. 


\subsection{CONCLUSIONS}

Analyses and testing to develop alternative glass compositions for the disposition of $\mathrm{PuO}_{2}$ led to the following conclusions:

- A phase equilibrium approach and glass science principals were successfully utilized to identify candidate alternative LaBS glass formulations. This methodology resulted in the identification of a formulation that moved the composition from a potential region of phase separation and into a region near a low melting point eutectic. This composition was dubbed the LaBS - Frit X composition.

- The Frit X composition was shown to have durability (as measured by the PCT) equivalent to the reference LaBS - Frit B composition and significantly better than the EA glass.

- Enhanced component solubility was observed in surrogate and $\mathrm{PuO}_{2}$ testing with the Frit $\mathrm{X}$ composition when compared to the reference Frit B composition.

- Improved devitrification behavior was observed with the Frit X composition. This will facilitate melter processing and could result in a lower glass melting temperature.

The presence of a $\mathrm{PuO}_{2}-\mathrm{HfO}_{2}$ solid solution phase was identified in the $\mathrm{Pu}$-containing Frit $\mathrm{X}$ glass upon initial fabrication. This could result in the potential to improve the plutonium leach performance in the repository by the formation of a highly insoluble phase with inherent neutron absorber. 


\subsection{RECOMMENDATIONS/PATH FORWARD}

In this study, a viable alternative LaBS glass composition (Frit X) was identified. Further detailed testing should be conducted on this composition to provide data to support repository modeling and to support project design activities. Specifically, the suite of performance tests currently being conducted on the reference Frit $\mathrm{B}$ composition should be conducted on the Frit X composition to provide the necessary data for repository modeling. The potential to form a $\mathrm{PuO}_{2}-\mathrm{HfO}_{2}$ phase in the glass should also be further pursued as a potential means to improve waste form performance. Additionally, as the feed stream chemistry destined for disposition via vitrification is better defined, a thorough glass formulation variability study should be performed to demonstrate that feed variations can be accommodated in the glass. Finally, this composition should be utilized in melter testing to support project design initiatives.

Consistent with waste glass formulation practices, test data with the Frit $\mathrm{X}$ composition should be reviewed to evaluate if any future iterative composition changes are deemed to be beneficial. The phase equilibria approach developed for this effort should be a valuable tool in these assessments. 


\subsection{ACKNOWLEDGEMENTS}

The authors wish to acknowledge many colleagues who contributed to the completion of this effort. Irene Reamer and Phyllis Workman performed the surrogate glass fabrication and testing. This included preparing the surrogate glass compositions, measuring the glass densities, performing the PCTs, performing glass heat treatments and preparing the frit needed to prepare the plutonium glass. Dave Best and Pat Toole performed the surrogate glass chemical analyses and PCT leachate analyses in the SRNL Mobile Laboratory. Tracy Rudisill provided the $\mathrm{PuO}_{2}$ to make the plutonium glass and directed the analyses and interpretation of the results on the $\mathrm{PuO}_{2}$ material. Mona Galloway prepared the plutonium glass in the shielded cells facility. Kevin Kalbaugh performed the heat treatment on the plutonium glass. Mike Summer and Jack Durden performed the SEM analyses and Art Jurgensen and David Missimer conducted the XRD analyses. David Diprete performed the liquid scintillation and gamma counting analyses.

Finally, the authors would like to thank Mimi Jones for her support in the technical editing of this report. 


\subsection{REFERENCES}

${ }^{1}$ Von Löffler, J., "Chemical Decolorization,” Glasstechniche Berichte, 10, 1932.

${ }^{2}$ Volf, M. B., Chemical Approach to Glass, Glass Science and Technology, Vol. 7, Elsevier Science Publishing Co. Inc., New York, 1984.

3 Bibler, N. E., W. G. Ramsey, T. F. Meaker, and J. M. Pareizs, "Durabilities and Microstructures of Radioactive Glasses for Immobilization of Excess Actinides at the Savannah River Site," Mat. Res. Soc. Symp. Proc., Vol. 412, Materials Research Society, Pittsburgh, PA, 1995.

${ }^{4}$ Meaker, T. F., W. G. Ramsey, J. M. Pareizs, and D. G. Karraker, "Composition Development for Vitreous Plutonium Products," Environmental and Waste Management Issues in the Ceramic and Nuclear Industries II, Ceramic Transactions, Vol. 72, American Ceramic Society, Westerville, OH, 1996.

${ }^{5}$ Meaker, T. F., "Compositional Development of a Plutonium Surrogate Glass without Listed RCRA Elements (Lead and Barium) - (U), WSRC-TR-96-0322, Westinghouse Savannah River Company, Aiken, SC, 1996.

${ }^{6}$ Vienna, J. D., D. L. Alexander, H. Li, M. J. Schweiger, D. K. Peeler, and T. F. Meaker, "Plutonium Dioxide Dissolution in Glass," PNNL-11346, UC-510, Pacific Northwest National Laboratory, Richland, WA, 1996.

${ }^{7}$ Meaker, T. F. and N. E. Bibler, "Characterization and Product Consistency Leach Tests on Lanthanide Borosilicate Glasses Containing Plutonium and Uranium or Impurities," contained in Plutonium Immobilization: The Glass Option - A Compendium of Reports and Presentations, WSRC-RP-9700902, Westinghouse Savannah River Company, Aiken, SC, 1997.

${ }^{8}$ Meaker, T.F. and D. K. Peeler, "Solubility of Independent Plutonium Bearing Feed Streams in a HfBased LaBS Frit," contained in Plutonium Immobilization: The Glass Option - A Compendium of Reports and Presentations, WSRC-RP-97-00902, Westinghouse Savannah River Company, Aiken, SC, 1997.

${ }^{9}$ Meaker, T. F. and N. E. Bibler, "Comparison of the Durabilities and Microstructures of an Amorphous and Devitrified Plutonium Bearing Lanthanide Borosilicate Glass (U)," contained in Plutonium Immobilization: The Glass Option - A Compendium of Reports and Presentations, WSRC-RP-9700902, Westinghouse Savannah River Company, Aiken, SC, 1997.

${ }^{10}$ Meaker, T. F. and N. E. Bibler, "Characterization and Product Consistency Leach Tests of Lanthanide Borosilicate Glasses Containing Plutonium and Uranium or Impurities (U)," contained in Plutonium Immobilization: The Glass Option - A Compendium of Reports and Presentations, WSRC-RP-9700902, Westinghouse Savannah River Company, Aiken, SC, 1997.

${ }^{11}$ Jantzen, C. M., N. E. Bibler, D. C. Beam, C. L. Crawford and M. A. Pickett, "Characterization of the Defense Waste Processing Facility (DWPF) Environmental Assessment (EA) Glass Standard Reference Material (U)," WSRC-TR-92-346, Rev. 1, 1993. 
12 "Standard Test Methods for Determining Chemical Durability of Nuclear, Hazardous, and Mixed Waste Glasses and Multiphase Glass Ceramics: The Product Consistency Test (PCT)," American Society for Testing and Materials (ASTM), ASTM C1285-02, West Conshohoken, PA. 2002.

${ }^{13}$ Ramsey, W.G., Bibler, N.E., and Meaker, T.F., "Compositions and Durabilities of Glasses for Immobilization of Plutonium and Uranium," Waste Management '95, Record 23828-23907, WM Symposia, Inc., Tucson, AZ, 1995.

${ }^{14}$ Meaker, T.F., "Homogeneous Glass Processing Region Defined for a Lanthanide Borosilicate Glass Composition for the Immobilization of Plutonium Using Thorium as a Surrogate," - (U), WSRC-TR96-0323, Westinghouse Savannah River Company, Aiken, SC, 1996.

${ }^{15}$ Jones, T., J. Marra, D. Immel, and B. Meers, "Glass Macrocracking Determination in Prototypic Cans Containing Lanthanide Borosilicate Glass," WSRC-TR-06-00015, Washington Savannah River Company, Aiken, SC, 2006.

16 Schumacher, R. F., D. S. McIntyre, D. K. Peeler, and J. M. Pareizs, "Volatilization Studies of a Lanthanide Lead Borosilicate Glass," Environmental and Waste Management Issues in the Ceramic and Nuclear Industries IV, Ceramic Transactions, Vol. 93, American Ceramic Society, Westerville, $\mathrm{OH}, 1999$.

${ }^{17}$ McCauley, R. A., "Corrosion - A Review of Some Fundamentals," Corrosion of Materials by Molten Glass, Ceramic Transactions, Vol. 78, American Ceramic Society, Westerville, OH, 1996.

${ }^{18}$ Marra, J. C., J. W. Congdon, A. L. Kielpinski, R. F. Schumacher, A. Applewhite-Ramsey, J. Etheridge, and R. Kirkland, "Corrosion Assessment of Refractory Materials for Waste Vitrification," Corrosion of Materials by Molten Glass, Ceramic Transactions, Vol. 78, American Ceramic Society, Westerville, $\mathrm{OH}, 1996$.

19 C.M. Jantzen, J. B. Pickett, C. C. Herman, and J. C. Marra, "Methods of Vitrifying Waste with Low Melting High Lithia Glass Compositions (LAMPTM)," U.S. No. 6,258,994-B1, No. 6,145,343, No. 6,624,103-B2, No. 6,630,419, No 6,812, 174, 2000-2004.

20 Jantzen, C. M., J. B. Pickett, K. G. Brown, T. B. Edwards, and D. C. Beam, "Process/Product Models for the Defense Waste Processing Facility (DWPF): Part I. Predicting Glass Durability from Composition using a Thermodynamic Hydration Energy Reaction Model (THERMO)," WSRC-TR-93672, Westinghouse Savannah River Company, Aiken, SC, 1997.

${ }^{21}$ Etherington, H., Nuclear Engineering Handbook, McGraw-Hill Book Co., New York, 1958.

${ }^{22}$ Rai, D., Y. Xia, N. J. Hess, D. M. Strachan, and B. P. Mcgrail, "Hydroxo and Chloro Complexes/Ion Interactions pf $\mathrm{Hf}^{4+}$ and the solubility of $\mathrm{HfO}_{2}(\mathrm{am})$, J. Sol. Chem., 30, 1991.

${ }^{23}$ Marra, J. C., C. L. Crawford, and N. E. Bibler, "Glass Fabrication and Product Consistency Testing of Lanthanide Borosilicate Frit B Composition," WSRC-TR-2006-00033, Washington Savannah River Company, Aiken, SC, 2006. 
WSRC-TR-2006-00031

Revision 0

This page intentionally left blank. 